University of Louisville

ThinkIR: The University of Louisville's Institutional Repository

8-2015

\title{
Canterbury and the crown : how the personal relationships between Tudor monarchs and their Archbishop of Canterbury affected the Church in England.
}

Mary Alexandra Covington

University of Louisville

Follow this and additional works at: https://ir.library.louisville.edu/etd

Part of the European History Commons

\section{Recommended Citation}

Covington, Mary Alexandra, "Canterbury and the crown : how the personal relationships between Tudor monarchs and their Archbishop of Canterbury affected the Church in England." (2015). Electronic Theses and Dissertations. Paper 2207.

https://doi.org/10.18297/etd/2207

This Master's Thesis is brought to you for free and open access by ThinkIR: The University of Louisville's Institutional Repository. It has been accepted for inclusion in Electronic Theses and Dissertations by an authorized administrator of ThinkIR: The University of Louisville's Institutional Repository. This title appears here courtesy of the author, who has retained all other copyrights. For more information, please contact thinkir@louisville.edu. 


\title{
CANTERBURY AND THE CROWN: HOW THE PERSONAL RELATIONSHIPS BETWEEN TUDOR MONARCHS AND THEIR ARCHBISHOP OF CANTERBURY AFFECTED THE CHURCH IN ENGLAND
}

\author{
By \\ Mary Alexandra Covington \\ B.A., University of Indianapolis, 2013
}

\begin{abstract}
A Thesis
Submitted to the Faculty of the

College of Arts and Sciences of the University of Louisville in Partial Fulfillment of the Requirements

for the Degree of
\end{abstract}

\author{
Master of Arts \\ in History
}

\author{
Department of History \\ University of Louisville \\ Louisville, Kentucky
}

August 2015 
Copyright 2015 by Mary Alexandra Covington All Rights Reserved 

CANTERBURY AND THE CROWN: HOW THE PERSONAL RELATIONSHIPS BETWEEN TUDOR MONARCHS AND THEIR ARCHBISHOP OF CANTERBURY AFFECTED THE CHURCH IN ENGLAND

\author{
By \\ Mary Alexandra Covington \\ B.A., University of Indianapolis, 2013 \\ A Thesis Approved on
}

August 3, 2015

by the following Thesis Committee

John McLeod Thesis Director

Genevieve Carlton

Dale Billingsley 


\section{DEDICATION}

This thesis is dedicated to my parents

John and Kathy Covington

who have supported and encouraged me throughout this entire process. 


\section{ABSTRACT \\ CANTERBURY AND THE CROWN: HOW THE PERSONAL RELATIONSHIPS BETWEEN TUDOR MONARCHS AND THEIR ARCHSBIHSOPS OF CANTERBURY AFFECTED THE CHURCH IN ENGLAND}

Mary Alexandra Covington

August 3, 2015

This thesis discusses how the personal relationships between the monarchs of the Tudor period in England and their Archbishops of Canterbury affected the Church in England, particularly after Henry VIII broke with Rome. Through the examination of the correspondence of the individuals included one can understand the personal relationships and how the archbishops interacted with their respective monarch(s). Two chapters discuss Archbishop Cranmer his relationships with Henry and Edward VI and how Cranmer enacted some reform under Henry but more under Edward. The fourth chapter evaluates the relationship between Mary I and Reginald Pole and how they moved England back to Catholicism. The final chapter discusses Elizabeth I and her first archbishop, Matthew Parker, and how they navigated a middle ground between Protestantism and Catholicism. The results of this study show that each archbishop and monarch worked together differently and that their personal relationships affected how the Church in England functioned. 


\section{TABLE OF CONTENTS}

\section{PAGE}

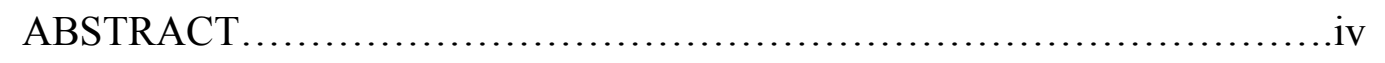

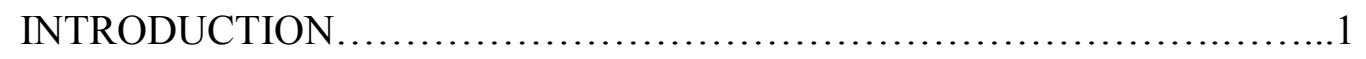

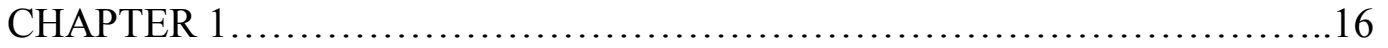

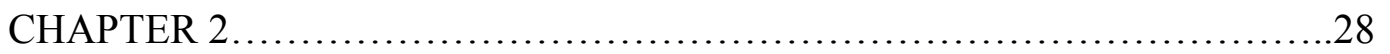

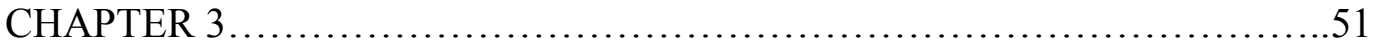

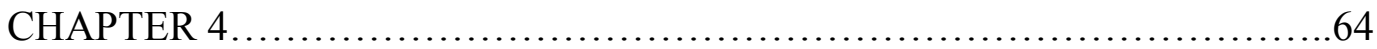

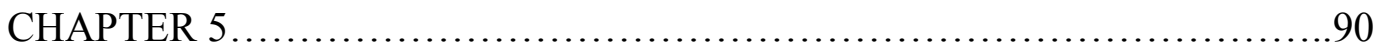

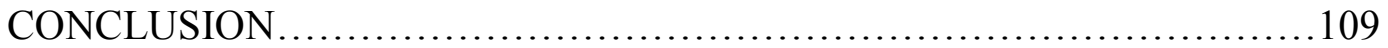

REFERENCES...................................................... 118

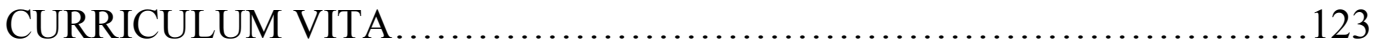




\section{INTRODUCTION}

The English Reformation was one of the most famous and formative events of British history. It began with Henry VIII breaking from the Roman Catholic Church and starting a new institution: the Church of England. The Reformation separated England from Catholic Europe and altered the country's path. Religion and the church affected all aspects of life in England and on the continent, including politics and government.

Religion in England remained much the same in practice, with a few minor differences at first, but the most important of those was that the monarch was now the Supreme Head of the Church in England. While the monarch was the head of the Church, the Archbishop of Canterbury continued to act as the principal spiritual leader in England.

The Archbishop of Canterbury is the most senior of the two archbishops in England. The office was established in 597 C.E. as a means for the Church to gain a foothold in Britain. The original mission was to bring Christianity to England and convert as many of its residents as possible, especially the rulers of the various kingdoms that existed at that time. ${ }^{1}$ Following the unification and conversion of England, the role of archbishop evolved into the spiritual leader of the Church in England and also an advisor to the monarch. ${ }^{2}$ Before the break with Rome, a candidate for archbishop was chosen by the monarch with the support of the government. The candidate was then elected by a group of priests from the diocese of Canterbury called the canons. After this period of election, the candidate must be approved by the pope before being consecrated

\footnotetext{
${ }_{1}^{1}$ Colin Buchanan, Historical Dictionary of Anglicanism (Lanham, MD: Scarecrow Press INC., 2006), 80. ${ }^{2}$ Ibid.
} 
into the office. After the break, the selected candidate still had to go through the election process within the Church in England, but the approval of the pope was no longer required for the new archbishop's consecration.

The archbishops were in charge of the Church in England but they could also exercise the powers of the papacy in England. People could still appeal to Rome in the event that they disagreed with the archbishop's ruling, but those appeals were difficult to achieve. $^{3}$ The archbishops supervised the clergymen and held a clerical parliament that had the power to create laws for the church and even provided the King with new taxes upon the country and church. ${ }^{4}$ The archbishops also presided over ecclesiastical courts that addressed matters within the church in England, such as the misbehavior of clergymen. Over the centuries, the archbishops began to take a more active role in the political environment in England as advisors to the monarch. Archbishops often acted as liaisons between the pope and monarchs, but also advised the monarchs and held high offices within the royal court. For example, Archbishop William Warham served as Lord Chancellor under Henry VII and Henry VIII and Thomas Cranmer served as an advisor to Henry VIII and tutor and advisor to Edward VI.

The role of Archbishop of Canterbury altered during the Tudor period. Before Henry VIII broke from Rome, the archbishops and clergymen in England recognized the pope as the head of the church. However, after the break, the clergy were expected to accept the monarch in England as the supreme head of the church. Those clergymen in England who accepted the monarch as the Supreme Head of the Church in England were allowed to remain, but those who disagreed were exiled or worse. An example is

\footnotetext{
${ }^{3}$ David H. Pill, The English Reformation 1529-58 (Totowa, NJ: Rowan and Littlefield, 1973), 14.

${ }^{4}$ Ibid.
} 
Reginald Pole, who was exiled after publishing his book Defense of the Unity of the Church, which chastised Henry for splitting from Rome and urged him to reconcile with the pope. ${ }^{5}$

Henry and his successors, Edward VI, Mary I, and Elizabeth I, all had their own impact on the Church of England. They also had their own unique relationships with their archbishops of Canterbury. When Henry separated from Rome, he altered the position of the archbishop of Canterbury. Henry began the transformation of the Church in England when he broke with Rome and his successors continued to transform the church during their reigns. With these changes, the relationship between the archbishop and the monarch shifted. The archbishop and clergy no longer obeyed the pope, except during the reign of Mary I. Instead, they only served the monarch, who after parliament passed Henry VIII's 1534 Act of Supremacy was the Supreme Head of the Church in England. ${ }^{6}$ This thesis will examine the personal relationships between the archbishops of Canterbury and the monarchs of Tudor England from Henry VIII through the early years of Elizabeth I's reign and how their relationships affected the Church of England. Together, the monarchs and archbishops dealt with the problems that plagued the church in England and implemented the policies that formed the religious reformations in England.

Some of the archbishops and monarchs had relationships before the monarch came to power or before the appointment of the archbishop. For example, Henry knew Thomas Cranmer before Cranmer's appointment as archbishop. Cranmer's loyalty to Henry in the years leading up to his nomination was the main reason he was chosen to

\footnotetext{
${ }^{5}$ Pole, Reginald and Joseph G. Dwyer, translator. Defense of the Unity of the Church. Westminster: Newman Press, 1965.

${ }^{6}$ John Guy, Tudor England (Oxford: Oxford University Press, 1988), 135.
} 
succeed Archbishop Warham. Cramer was also godfather to Henry's son, Edward, and kept in contact with the boy before he became king. When Edward came to the throne, Cranmer acted as a tutor and father figure, guiding the young king.

Other relationships began when the monarch came to power. For example, Mary and Reginald Pole's relationship began when Mary became queen of England. When Mary came to the throne she turned the church in England back to Roman Catholicism and to the authority of the papacy with the help of her papal legate and eventual archbishop, Pole. Pole and Mary's relationship was more personal than the others because the two were drawn together by their desire to return England to their idea of the true faith. They not only respected one another, but they also loved each other as family. Under Elizabeth the country turned away from Roman Catholicism and took the middle path between Catholicism and Protestantism that became known as Anglicanism. Elizabeth's first archbishop, Matthew Parker, devoted himself to her service based on a promise he made to her mother, Anne Boleyn, years before Elizabeth came to the throne. ${ }^{7}$ Parker did everything Elizabeth asked of him, but she did not always heed his advice, choosing instead to follow the advice of her political advisors.

Historians have dedicated numerous books and articles to the Tudor dynasty and their impact on English history. However, few have systematically studied the evolving relationship between monarchs and archbishops in this pivotal transformation. The subjects of these volumes include comprehensive studies of the period, biographies of the monarchs, politicians, and bishops, studies of the English Reformation, and Tudor government. In his book, Tudor England, John Guy writes a comprehensive study of the

\footnotetext{
${ }^{7}$ John Bruce Esq. and Rev. Thomas Thomason Perowne, M.A. Eds, The Correspondence of Matthew Parker D.D., Archbishop of Canterbury (Cambridge: Cambridge University Press, 1853), 70.
} 
years in which England was ruled by the Tudor dynasty. ${ }^{8}$ The volume covers about 150 years of English history beginning with the Wars of the Roses and culminating in the Elizabethan era. He argues that "the strength of the state and of corporate government were linked." 9 He states that the factionalism under Henry VIII disrupted the peace and stability of the court but "the homogeneity of Court and Privy Council under Elizabeth was a major source of stability." 10 Guy discusses many different topics, among them the English Reformation and the consequences of Henry VIII's break with Rome in the 1530s. While Guy does not go into extreme detail about each individual archbishop of Canterbury, aside from Thomas Cranmer, he does describe their influence and different roles they played throughout the Tudor Period.

Another book that covers the Tudor era is Tudors: The History of England from Henry VIII to Elizabeth I by Peter Ackroyd. ${ }^{11}$ In this work, Ackroyd agrees that the English Reformation was instigated by the Henry's desire to end his first marriage. Ackroyd refers to it as "a political and dynastic matter" to meet the king's goals. ${ }^{12}$ Ackroyd uses the English Reformation as one of the principal events of the Tudor period. He revisits it throughout the text and explains how religion was one of the most important and controversial topics to the monarchs and nobles in England during the reign of every Tudor monarch. Ackroyd describes the changes in religious policy and how each ruler implemented their own alterations to the English religious environment. He says that England "became Protestant by degrees," slowly making the change over the course of

\footnotetext{
${ }^{8}$ Guy, John. Tudor England. Oxford: Oxford University Press, 1988.

${ }^{9}$ Guy, Tudor England, 455.

10 Ibid.

${ }^{11}$ Ackroyd, Peter. Tudors: The History of England from Henry VIII to Elizabeth I. New York: Thomas Dunne Books, 2012.

${ }^{12}$ Peter Ackroyd, Tudors: The History of England from Henry VIII to Elizabeth I (New York: Thomas Dunne Books, 2012), 467.
} 
the Tudor period. ${ }^{13}$ Ackroyd uses the archbishops as influencing characters in the lives of the monarchs, but does not focus on the relationships between the monarchs and the archbishops.

There are also many biographies of the Tudor monarchs and the archbishops. Ackroyd's book, Tudors, recounts the lives of Henry VIII, Edward VI, Mary I, and Elizabeth I, but other texts cover those monarchs in more detail. Alison Weir wrote a book entitled Henry VIII: The King and His Court, in which she describes the life of Henry VIII and his relationships with different members of his court, such as Thomas Cranmer and Thomas Cromwell. ${ }^{14}$ Weir argues that Henry VIII's image has been dramatized over the centuries and she attempts to revise his image through her analysis of his personality, court, and personal relationships. Jennifer Loach wrote a biography of Edward VI, Edward VI, in which she argues that Edward's reign cannot be understood by only looking at the years Edward ruled, but that one must also consider the final years of Henry's reign, Mary's reign, and the early years of Elizabeth's reign. ${ }^{15}$ Loach states that many of the personnel of the court remained the same during these reigns, which resulted in some continuity in government despite the change in monarch. She also argues that Edward behaved more as a spoiled child than as a gladiator for his faith who sought only to purify his church. ${ }^{16}$ Diarmaid MacCulloch wrote a biography of Thomas Cranmer, who served as archbishop under both Henry and Edward before being arrested and executed by Mary. In that book, Thomas Cranmer: A Life, MacCulloch shows how Cranmer journeyed from a good Catholic priest and theologian to the face of the

\footnotetext{
${ }^{13}$ Ibid., 468.

${ }^{14}$ Weir, Alison. Henry VIII: The King and His Court. New York: Ballentine Books, 2001.

15 Jennifer Loach, edited by George Bernard and Penry Williams, Edward VI (New Haven: Yale University Press, 1999), 184.

${ }^{16}$ Ibid.
} 
Reformation in England. ${ }^{17}$ MacCulloch argues that Cranmer was often confused and conflicted when it came to his faith and that his greatest legacy was his written work, which includes The Book of Common Prayer. MacCulloch also details Cranmer's relationships with both kings he served, how they respected each other, and also used each other to their mutual benefit.

Judith Richards and Linda Porter both wrote biographies of Mary that paint her in a favorable light. Richards, in Mary Tudor, credits Mary with blazing the trail for all future female monarchs, including her sister Elizabeth. ${ }^{18}$ She argues that "she (Mary) ruled the country with some success at a very difficult and divided time." ${ }^{\prime 19}$ Richards also discusses Mary's marriage to Philip and how his presence in England affected the restoration of the church and how Mary ran her country. David Starkey wrote a biography on Elizabeth, entitled Elizabeth: The Struggle for the Throne. ${ }^{20}$ In this biography, Starkey details how Elizabeth went from being illegitimate to Queen of England. He argues that the events of Elizabeth's youth are what "shaped her world" and how she reacted to the many challenges she faced. ${ }^{21}$ He also describes her struggles throughout her reign, such as whether or not she would marry and how she once again altered the church in England.

Dale Hoak put together a collection of essays dedicated to how politics worked in Tudor England. This volume of essays, Tudor Political Culture, includes essays by Hoak, Robert Tittler, Norman Jones, and John Guy, among others. ${ }^{22}$ Essays in this book

\footnotetext{
${ }^{17}$ MacCulloch, Diarmaid. Thomas Cranmer: A Life. New Haven: Yale University Press, 1996.

${ }^{18}$ Richards, Judith. Mary Tudor. London: Routledge, 2008.

${ }^{19}$ Judith Richards, Mary Tudor (London: Routledge, 2008), 11.

20 Starkey, David. Elizabeth: The Struggle for the Throne. New York: Harper Collins Publishers, 2001.

${ }^{21}$ David Starkey, Elizabeth: The Struggle for the Throne (New York: Harper Collins Publishers, 2001), xi.

${ }^{22}$ Hoak, Dale, ed. Tudor Political Culture. Cambridge: Cambridge Universtiy Press, 1995.
} 
discuss topics such as the royal image, relationships at court, and Tudor parliaments. Norman Jones's essay, "Parliament and the Political Society of Elizabethan England," discusses the power of parliament during Elizabeth's reign and how it could be both a passive power and more powerful than the monarch. ${ }^{23}$ In this essay Jones argues that the men in Parliament voted in their own interests and rarely considered what was best for England. $^{24}$

Another book of essays that covers the Tudor period is The Tudor Monarchy, edited by John Guy. ${ }^{25}$ This book is broken into three sections that each deal with a different theme, namely Renaissance monarchy, personality and politics, and polity and government. Historians, other than Guy, who contributed to this volume include David Starkey and G.R. Elton. Elton's chapter, “Tudor Government: The Points of Contact: Parliament," discusses the function of government in the Tudor period. ${ }^{26}$ Elton argues in his chapter that the Tudor government relied on maintaining a balance of power between the local and central authorities but also on ensuring that the rivalries of court did not get out of hand with competing for patronage. ${ }^{27}$ One of Starkey's two chapters, "Court and Government," discusses how the court functioned under Henry VIII and the royal household. ${ }^{28}$ He not only discusses the politics but also how the "household

\footnotetext{
${ }^{23}$ Norman Jones, "Parliament and the Political Society of Elizabethan England", in Tudor Political Culture, ed. Dale Hoak (Cambridge: Cambridge Universtiy Press, 1995), 227.

${ }^{24}$ Ibid., 242.

${ }^{25}$ Guy, John, ed. The Tudor Monarchy. London: Arnold, 1997.

${ }^{26}$ Elton, G.R. "Tudor Government: The Points of Contact: Parliament." In The Tudor Monarchy, edited by John Guy, 340-355. London: Arnold, 1997.

${ }^{27}$ G.R. Elton, "Tudor Government: The Points of Contact: Parliament," in The Tudor Monarchy, ed. John Guy, (London: Arnold, 1997), 342-343.

${ }^{28}$ Starkey, David. "Court and Government." In The Tudor Monarchy, edited by John Guy, 189-213. London: Arnold, 1997.
} 
government," functioned during Henry's reign. ${ }^{29}$ Guy wrote essays on critiques of the Tudor monarchy and also on specific figures and their influence on the Tudor court, such as Thomas Cromwell and Thomas Wolsey. Guy's chapter "Thomas Cromwell and the Intellectual Origins of the Henrician Revolution," analyzes the origins of the intellectual concept of empire in Henry's court and how Cromwell was the man behind Henry. ${ }^{30}$ Another one of Guy's chapters, "Wolsey and the Tudor Polity," shows how Wolsey contributed to the King's council and in local government. ${ }^{31}$

There are also several volumes on the English Reformation and how it affected England. David Pill's book, The English Reformation 1529-58, covers the English Reformation from its beginning through the end of Mary I's reign in $1558 .^{32}$ Pill mentions the different archbishops on multiple occasions but only as they affected the Reformation. Henry VIII's first archbishop, William Warham, is barely mentioned, aside from his death. Cranmer is mentioned the most of all the archbishops from this time period, but he also played the biggest role throughout the Reformation. A.G. Dickens also dedicates a book, The English Reformation, to the study of the English Reformation. ${ }^{33}$ In this book, Dickens discusses what brought about the English Reformation but also how it affected England's social, religious, and cultural matters. Dickens depicts how life changed for those in charge of the country and how it affected the common people of England. Cranmer and Wolsey are discussed the most in this volume but the other archbishops are also mentioned, such as Warham, Pole, and Parker.

\footnotetext{
${ }^{29}$ David Starkey, "Court and Government" in The Tudor Monarchy, ed., John Guy, 189-213 (London: Arnold, 1997), 190.

${ }^{30}$ Guy, John. "Thomas Cromwell and the intellectual origins of the Henrician Revolution." In The Tudor Monarchy, edited by John Guy, 213-233. London: Arnold, 1997.

${ }^{31}$ Guy, John. "Wolsey and the Tudor Polity." In The Tudor Monarchy, edited by John Guy, 308-329. London: Arnold, 1997.

${ }_{32}$ Pill, David H. The English Reformation 1529-58. Totowa, NJ: Rowan and Littlefield, 1973.

${ }^{33}$ Dickens, A.G. The English Reformation. New York: Schocken Books, 1964.
} 
The Reign of Henry VIII: Politics, Policy, and Piety, edited by Diarmaid MacCulloch, is a collection of essays by different historians about the reign and policies of Henry VIII. ${ }^{34}$ The essays discuss topics including Henry's politics, his religious reforms, foreign policy, and his divorce from his first wife. One of the chapters is an essay by John Guy about the reforms of Henry's government and the involvement of Thomas Cromwell and Thomas Wolsey. ${ }^{35}$ In this chapter, Guy argues that "a reassessment of the role of Henry VIII's ministers cannot usefully be undertaken without reference to wider issues of context." ${ }^{, 36}$ Another written by Virginia Murphy is dedicated to the divorce of Henry and Katherine of Aragon. ${ }^{37}$ Murphy argues that "the king followed a coherent policy," and that he "consistently attacked his marriage on the grounds which disputed the pope's authority to dispense, asserting that his union contravened divine law and could in no circumstances be dispensed from." ${ }^{38}$

Peter Marshall edited another book of essays on the English Reformation, The Impact of the English Reformation 1500-1640. ${ }^{39}$ This book includes essays by historians such as A.G. Dickens, Eamon Duffy, and Christopher Haigh. The essays are divided into three sections: origins, implementation, and outcomes. Throughout, Cranmer is the only archbishop who is mentioned in any detail. Jennifer Loach and Robert Tittler also edited

\footnotetext{
${ }^{34}$ MacCulloch, Diarmaid. The Reign of Henry VIII: Politics, Policy, and Piety. New York: St. Martin's Press, 1995.

${ }^{35}$ Guy, John. "Thomas Wolsey, Thomas Cromwell and the Reform of the Henrician Government." In The Reign of Henry VIII: Politics, Policy, and Piety, edited by Diarmaid MacCulloch, 35-57. New York: St. Martin's Press, 1995.

${ }^{36}$ John Guy, "Thomas Wolsey, Thomas Cromwell and the Reform of the Henrician Government," in The Reign of Henry VIII: Politics, Policy, and Piety, ed. Diarmaid MacCulloch (New York: St. Martin's Press, 1995), 35.

${ }^{37}$ Murphy, Virginia. "The Literature and Propaganda for Henry VIII's First Divorce." In The Reign of Henry VIII: Politics, Policy, and Piety, edited by Diarmaid MacCulloch, 135-158. New York: St. Martin's Press, 1995.

${ }^{38}$ Virginia Murphy, "The Literature and Propaganda for Henry VIII's First Divorce," in The Reign of Henry VIII: Politics, Policy, and Piety, ed. Diarmaid MacCulloch (New York: St. Martin's Press, 1995), 136.

${ }^{39}$ Marshall, Peter, ed. The Impact of the English Reformation 1500-1640. London: Arnold, 1997.
} 
a book of essays entitled the Mid-Tudor Polity, c. 1540-1560. ${ }^{40}$ This collection of essays covers the later years of Henry's reign and both Edward and Mary's reigns. These essays cover a range of topics including Mary's Privy Council, social policies of England through Edward and Mary's reigns, and the clergy under Mary. Cranmer and Pole are the two archbishops who are mentioned most often in this study. Pole is discussed at length in the chapter by Pogson, "the Legacy of the Schism: Confusion, Continuity and Change in the Marian Clergy."

Eamon Duffy, in The Stripping of the Altars: Traditional Religion in England $c$. 1400-1580, discusses the destruction of the monasteries and religious houses in England during the Tudor era. ${ }^{42}$ This book also describes the beginning of the end of the Roman Catholic Church in England. Duffy also co-edited a collection of essays with David Loades called The Church of Mary Tudor. ${ }^{43}$ These essays cover a range of topics including Pole's legation, Spanish influence on English policies, and the restoration of the Catholic mass during the Marian regime. Duffy also wrote another book, Fires of Faith: Catholic England under Mary Tudor, in which he goes into more detail about the Marian Restoration including how while the burnings of Protestants was inexcusable they were also necessary according to the law. ${ }^{44}$

\footnotetext{
${ }^{40}$ Loach, Jennifer and Robert Tittler, eds. The Mid-Tudor Polity, c. 1540-1560. Totowa, New Jersey: Rowman and Littlefield, 1980.

${ }^{41}$ Pogson, Rex H. "The Legacy of the Schism: Confusion, Continuity and Change in the Marian Clergy." In The Mid-Tudor Polity, c. 1540-1560, edited by Jennifer Loach and Robert Tittler, 116-136. Totowa, New Jersey: Rowman and Littlefield, 1980.

${ }^{42}$ Duffy, Eamon. The Stripping of the Altars: Traditional Religion in England c. 1400-1580. New Haven: Yale University Press, 1992.

${ }^{43}$ Duffy, Eamon and David Loades, eds. The Church of Mary Tudor. Aldershot Hants, England: Ashgate, 2006.

${ }^{44}$ Duffy, Eamon. Fires of Faith: Catholic England under Mary Tudor. New Haven: Yale University Press, 2009.
} 
An examination of the relationship between the archbishops of Canterbury and the Tudor monarchs will help show how the policies of the church emerged and were put into action during the Tudor Era. The personal relationships between the archbishops and monarchs are what shaped the Anglican Church during the reign of each Tudor monarch. The archbishops included in this thesis were selected because they were the ones who helped form the policies of the Anglican Church following the break with Rome. Through the examination of the letters between the archbishops and the monarchs one can see how the individuals in question related to one another.

The letters of the archbishops are the principal primary sources used in this thesis. The correspondence between the archbishops and monarchs, among other prominent members of court, reveal many things about the time period. For example, the examination of Cranmer's letters to Henry show his enormous respect for the king and also his subservience to Henry. Cranmer's correspondence with Edward reveals Cranmer's paternal nature toward the boy. Their correspondence also reflects a relationship between a teacher and his pupil. However, the letters between Mary and Pole show how much Pole grew to care for Mary during their time together. His letters show how he cared about her personal welfare as much as he did the status of the church in England. Cranmer and Matthew Parker's letters were collected and published as a part of the Parker Society Collection. ${ }^{45}$ Pole's extensive correspondence was edited by

\footnotetext{
${ }^{45}$ Bruce Esq., John and Rev. Thomas Thomason Perowne, M.A. Eds. The Correspondence of Matthew Parker D.D., Archbishop of Canterbury. Cambridge: Cambridge University Press, 1853.

Cox, Rev. John Edmund, ed. The Works of Thomas Cranmer Volume II: Miscellaneous Writings and Letters of Thomas Cranmer, Archbishop of Canterbury, Martyr, 1556. Cambridge: Cambridge University Press, 1846.
} 
Thomas F. Mayer and Courtney B. Walters and organized into a four volume set that includes letters from his early career up until his death in $1558 .^{46}$

Each chapter will examine a different relationship between an archbishop and a monarch. The first chapter will provide some background information about the early years of Henry VIII's reign and his first archbishop, William Warham. This chapter will show how the archbishop of Canterbury functioned when the papacy was still head of the church in England as well as provide some background information as to why Henry chose to break with Rome.

The second chapter will focus on the relationship between Thomas Cranmer and Henry VIII. The correspondence between Cranmer and Henry VIII shows that they had a relationship based upon mutual respect. This relationship reflects the church during this time because under Henry, the Church in England was still mostly Catholic in practice but it no longer recognized the pope as the governing figure. Cranmer grew into a reformer during Henry's reign and hid many of his works that would become the foundation for the Protestant church under Edward VI because he feared angering Henry. Henry respected and loved Cranmer and allowed him to remain archbishop after Cranmer confessed to the king that he was married. However, Cranmer did not think that Henry could forgive an attack on his faith, so Cranmer kept his more controversial beliefs to himself. Cranmer rarely made any requests from the king and often pandered to the king in order to avoid retribution. Henry and Cranmer were close friends until Henry's death. One of the results of that closeness was that Henry trusted Cranmer with the education and welfare of his heir, Edward VI.

\footnotetext{
${ }^{46}$ Mayer, Thomas F. and Courtney B. Walters. The Correspondence of Reginald Pole, 4 vols. Aldershot, England: Ashgate, 2003.
} 
The next chapter will discuss the relationship between Cranmer and Edward VI, Henry's only living son. This chapter will show that Cranmer's relationship with Edward was more paternalistic than Cranmer's relationship with Henry. The letters from Cranmer to Edward were often full of praise for the boy's accomplishments, knowledge, and skills. Cranmer also wrote to Edward telling him he was the next Josiah, chosen to lead England to salvation through Protestantism. Cranmer was able to influence the young king more than his father and with the help of Edward's councilors Cranmer was able to finish the work he began under Henry VIII and reform the church in England.

The fourth chapter examines Mary I and her relationship with Reginald Pole. Mary was a devout Catholic and her accession to the throne also meant the return of papal authority in England. Her papal legate turned archbishop, Reginald Pole, wanted to return his home country to the control of Rome and the path to salvation. This mutual desire to restore Catholicism in England brought Mary and Pole together and helped them form a strong bond and love for one another. Through examination of Pole and Mary's correspondence, one can see how much they respected one another and how much Pole cared for Mary. Pole did his best to care for Mary and look after her well being. Mary respected Pole and did the best she could to follow Pole's advice regarding the restoration of Catholicism in England. Their relationship reflects the church in England at this time because their dedication to Catholicism brought England back under papal authority and practicing Roman Catholicism. Their devotion to reinstating Catholicism in England is what brought Mary and Pole together and also what briefly brought England back to Catholicism. 
The final chapter discusses Elizabeth and her first archbishop, Matthew Parker. When Elizabeth came to the throne, she unraveled her sister's work that brought the Catholic Church back to England. She chose Matthew Parker as her archbishop because she trusted him to do her bidding. Parker was devoted to serving Elizabeth based on a promise he made her mother, Anne Boleyn, before she was executed. Through the examination of the correspondence between Parker and Elizabeth, one can see that Parker was devoted to her service and gave her his best advice as a spiritual advisor. This relationship affected the church because Elizabeth usually took the advice of her political councilors over Parker and politics often made the decisions regarding religious matters in England after the break with Rome. Elizabeth did not want to commit to Protestantism or Catholicism so she tried to straddle the two faiths. She listened to Parker about some things but deferred to her political advisors and relied on them more than she did Parker.

Evaluation of these relationships reveals personal details about the monarchs and archbishops and shows how these individuals did what they had to in order to bring about the changes they desired. This examination will also facilitate a better understanding of the English Reformation and how it affected each individual relationship between the monarchs and archbishops. It will also show how the policies of the Anglican Church were formed through their interactions and how their relationships functioned. These personal relationships between the archbishops and the monarchs of Tudor England are responsible for the major changes that occurred within the Anglican Church during each monarch's reign. 


\section{CHAPTER 1 \\ WARHAM AND HENRY VIII: BEFORE THE BREAK}

The sixteenth century was a turbulent time for the Roman Catholic Church. Martin Luther and his Ninety-Five Theses threw Christians in Europe into chaos. Factions sprang up throughout different European countries, including France, the Germanic states, and England. The main catalyst for the English Reformation was Henry VIII's “Great Matter,” his wish for an annulment from his first wife, Katherine of Aragon. The Reformation in Europe was different from what happened in England. Henry's break with Rome stemmed from his desire to separate from the papacy, not alter religious doctrine or practice in England. On the continent, Luther led the movement to change the way the Roman Catholic Church operated as well as condemning church practices. His main target was the sale of indulgences, documents that allowed those who bought them to buy time out of purgatory and expedite their arrival in Heaven after death. $^{47}$

Henry VIII's reign is remembered for religious controversy and Henry's desire for a male heir to succeed him. This quest for a son was one of the driving forces behind many of Henry's actions, including the break from the Roman Catholic Church. John Guy includes a long list of reasons for Henry's break with Rome. The list includes “the fragmentation of humanism, the advent of the Reformation, a crescendo of anticlericalism at the inns of court, Anne Boleyn's support for reform, and the formation

${ }^{47}$ David H. Pill, The English Reformation 1529-58 (Totowa, NJ: Rowan and Littlefield, 1973), 38. 
of Court factions sustained by politico-religious ideology after Wolsey’s removal. ${ }^{24}$ This list stresses that it was the culmination of all of these things that brought about Henry's split from Rome. He had his own reasons to split with Rome, but others in England were also willing to embrace some religious reform and thus Henry had the support he needed to break with Rome.

Henry's father, Henry VII, was the final victor of the Wars of the Roses when Richard III was killed in battle in 1485 . Henry VII took the throne of England by force and the best way to safeguard his kingdom was to provide a strong male heir to succeed him to the throne. Henry VII had two sons, Arthur and Henry. Henry VII sought to strengthen his country further by creating a marriage alliance with Spain by marrying his oldest son, Arthur, to the daughter of Ferdinand and Isabella of Spain, Katherine of Aragon. Katherine married Arthur in 1501 but Arthur died soon after the wedding in 1502.

After his son's death, Henry VII wanted to maintain the alliance he brokered with Spain, so negotiations began to marry Katherine to Henry, the king's second son. ${ }^{49}$ The marriage took place in 1509, after Henry succeeded his father as King of England. However, because Katherine was a widow and, more importantly, the widow of the king's brother, many thought she was not fit to become England's next queen. According to the law, Katherine was Henry's sister after she married his brother and the Biblical Book of Leviticus forbids a marriage between a man and his brother's widow. Even though Katherine swore that she and Arthur never consummated their marriage, a papal dispensation was provided before the marriage took place. A papal dispensation arrived

\footnotetext{
${ }^{48}$ John Guy, Tudor England (Oxford: Oxford University Press, 1988), 116.

${ }^{49}$ Ibid., 76.
} 
in 1505 but the marriage did not officially take place until $1509 .{ }^{50}$ The consummation of Arthur and Katherine's marriage was a topic of debate among scholars when Henry began to set his annulment in motion in the 1520s. It was also the king's principal reason as to why he could no longer remain married to Katherine. However, they were married and the treaty that Henry VII made with Spain was finally fulfilled.

William Warham served as Henry's first Archbishop of Canterbury. Warham became archbishop in 1504 under Henry VII, and began his service as lord chancellor the same year. The lord chancellor was one of the most influential political positions of the day and their duties included leading the chancery, part of the high court in England. The lord chancellor also oversaw the courts and, for a time, kept the Great Seal of England. ${ }^{51}$ Warham held both of those positions when Henry came to the throne in 1509 . He resigned as lord chancellor in 1515 and Thomas Wolsey, cardinal and Archbishop of York, succeeded him. Wolsey is remembered as the one of the most influential political and religious forces during Henry's reign but Warham still remained significant in England. As archbishop, Warham still exercised a considerable amount of influence in England in spiritual matters. A.G. Dickens states that Warham was overshadowed by Wolsey and that Warham's career was directly affected by Wolsey's swift rise to power, which was the result of favor from Henry. ${ }^{52}$ Wolsey had more power and influence over the king than Warham did after 1515 . Wolsey became lord chancellor and established his own legatine court, a court that exercised the power of the papacy through the papal representative (legate), at Westminster. ${ }^{53}$

\footnotetext{
${ }^{50}$ Ibid.

${ }^{51}$ Alison Weir, Henry VIII: The King and His Court (New York: Ballentine Books, 2001), 86.

${ }^{52}$ A. G. Dickens, The English Reformation (New York: Schocken Books, 1964), 40.

${ }^{53}$ Pill, The English Reformation 1529-58, 14.
} 
Henry's reign and dynasty remained unsteady until Henry had an heir to succeed him. His father fought for years to cement his claim to throne and Henry still faced some backlash about how his family claimed the throne of England. Henry VIII felt that unless he had a male heir, the line of succession was not safe. ${ }^{54}$ After the death of his brother, Henry determined to have sons in order to secure his line of succession. He and Katherine announced quickly that they were expecting their first child, but that pregnancy ended in a stillbirth in $1510 .^{55}$ In 1511 , Katherine had a son named Henry, but the young prince died after only two months. It was not until 1516 that the royal couple bore a healthy child, a daughter named Mary. ${ }^{56}$ She was their only living child even though Katherine and Henry had many causes to hope throughout their twenty-four year marriage. It is difficult to determine exactly when the king and his wife began to grow apart, but one event that influenced Henry's disinterest in his wife was the arrival of the sister of one of his former mistresses.

Anne Boleyn was an ambitious young woman who captured the king's attention. She became another reason for why Henry wanted to annul his marriage to Katherine. She refused to become his mistress, something many women before her had never done, and Henry became obsessed with her. ${ }^{57}$ Anne made clear that she would never agree to be with him intimately until they were man and wife. She also promised him that she could give him sons, unlike his barren and aging wife. Anne Boleyn was also a supporter of religious reform. ${ }^{58}$ She encouraged Henry to end his marriage to Katherine, but she

\footnotetext{
${ }^{54}$ Peter Ackroyd, Tudors: The History of of England from Henry VIII to Elizabeth I (New York: Thomas Dunne Books, 2012), 42.

${ }^{55}$ Ibid., 5.

${ }^{56}$ Ibid., 18-19.

57 Ibid., 41.

${ }^{58}$ Guy, Tudor England, 116.
} 
also supported his eventual break with Rome, which would extend the king's power and provide him with more wealth. ${ }^{59}$ Sometime between 1528 and 1529, a lawyer named Simon Fish published a pamphlet called A Supplication for the Beggars. In this pamphlet, Fish attacked the clergy and the taxes demanded by the church. He also showed support for Luther's idea of "justification by faith alone." ${ }^{\circ 0}$ Anne Boleyn gave Henry a copy of this pamphlet in order to show him the value of reforming the church. ${ }^{61}$ With this new information and the promise of a son, Henry began his quest to end his marriage in the late $1520 \mathrm{~s}$, but it was years before he was successful.

Interestingly enough, Warham opposed Henry's marriage to Katherine from the beginning because her previous marriage had been to Henry's brother. But once Henry spoke of ending it, Warham defended the marriage. ${ }^{62}$ Pope Julius II provided a dispensation allowing the marriage to take place and there was no reason to end it in the eyes of the church. As a spokesman for the pope in England, Warham would not disagree with the pope on this matter, at least not openly. Weir states that while Warham supported the validity of the royal marriage, he often made concessions to support the king, even though he did not always agree with his decisions. ${ }^{63}$ Dickens states the Warham's apparent loss of power stems not only from Wolsey's rise to power but also to Warham's lack of urgency in attending to the needs of church reform when it was needed. ${ }^{64}$ The Church during the 1520 s and 1530 s was the target of Martin Luther and those who felt the church should change. Warham did not participate in the discussions

\footnotetext{
${ }^{59}$ Ackroyd, Tudors: The History of of England from Henry VIII to Elizabeth I, 59.

${ }^{60}$ G.W. Bernard, The King's Reformation: Henry VIII and the Remaking of the English Church (New Haven: Yale University Press, 2005), 278.

${ }^{61}$ Ackroyd, Tudors, 59.

${ }^{62}$ Guy, Tudor England, 89.

${ }^{63}$ Alison Weir, Henry VIII: The King and His Court (New York: Ballentine Books, 2001), 285.

${ }^{64}$ Dickens, The English Reformation, 40.
} 
of Luther and reform that men such as Thomas Cranmer and Matthew Parker supposedly took part in. ${ }^{65}$ Warham was more involved with religious matters within the province of Canterbury and with the bishops that he oversaw rather than the politics of the country.

However, Henry's determination to end his first marriage became the king's obsession of and Henry tried every avenue in order to succeed. The majority of the clergy agreed that the marriage had taken place under the blessing of the Church, especially since the Pope Julius II provided a dispensation. That did not stop Henry from appealing to Wolsey and charging him with the task of finding a way to end the marriage. Wolsey convened secret courts at Westminster to examine the marriage, canon law, and theology in order to find an answer for the king. ${ }^{66}$ Henry and Wolsey both appealed to scholars and theologians throughout England and Europe regarding the annulment. They sought to gain support from those who were well educated in scripture and law and could provide some input into how Henry could legally and theologically end his marriage. ${ }^{67}$

Henry was a religious man and his faith was important to him. Before the death of his brother, Henry studied theology with the goal of one day becoming Archbishop of Canterbury. ${ }^{68}$ Throughout his life, Henry heard mass on average three times a day. In 1521, Pope Leo X proclaimed Henry the Defender of the Faith for a pamphlet he wrote that denounced the teachings of Martin Luther. ${ }^{69}$ With this new title, Henry felt he earned the same amount of esteem from the pope as the kings of France and Spain, whom

\footnotetext{
${ }^{65}$ Ackroyd, Tudors, 27.

${ }^{66}$ Virginia Murphy, "The Literature and Propaganda of Henry VIII's First Divorce," in The Reign of Henry VIII: Politics, Policy, and Piety (New York: St. Martin's Press, 1995), ed., Diarmaid MacCulloch, 135.

${ }^{67}$ Catherine Fletcher, The Divorce of Henry VIII: The Untold Story from inside the Vatican (New York: Palgrave MacMillan, 2012), 117-120.

${ }_{68}^{6}$ Pill, The English Reformation, 45-46.

${ }^{69}$ Ibid., 40.
} 
the pope named the Most Christian King and the Most Catholic King, respectively. ${ }^{70}$ However devout Henry seemed, he was also a strong-willed man who did not like to take orders or follow the rules of others, including the pope.

Henry and his councilors worked tirelessly to prove that his marriage was unlawful and a sin in the eyes of God. According to Virginia Murphy, Henry had two potential courses that would prove the invalidity of his marriage. The first avenue was to find a technical flaw in the papal dispensation provided to Henry and Katherine before the marriage took place. If they could find any kind of mistake within the document, then Henry could claim it was void and declare the marriage invalid. ${ }^{71}$ The second avenue was to refer to scripture. The first passage of two that Henry and his council focused on was Leviticus 18:16. ${ }^{72}$ It states that it is a sin to see your brother's wife's nakedness because it is your brother's nakedness. The second passage, Leviticus 20:21, states the same idea but also added that if one broke that rule, then as punishment, they shall be childless. $^{73}$

There were problems with the use of scripture to defend the king's desire to end his first marriage. The first was translation loss or errors in the interpretation. The verses from Leviticus were re-translated by Henry's scholars from Hebrew into Latin so that the verses could apply to Henry's situation more specifically. ${ }^{74}$ When the verses were translated into Latin, they fit Henry's situation perfectly because they said that the

\footnotetext{
${ }^{70}$ Ibid.

${ }^{71}$ Virginia Murphy, "The Literature and Propaganda of Henry VIII's First Divorce," in The Reign of Henry VIII: Politics, Policy, and Piety, ed., Diarmaid MacCulloch, 137.

${ }^{72}$ Ibid., 136.

${ }^{73}$ Ibid.

${ }^{74}$ Ibid., 139.
} 
marriage between a man and his brother's widow would be punished by the loss of any "sons", instead of "children" in the Hebrew version. ${ }^{75}$

Another problem Henry faced was a contradictory passage in Deuteronomy. The verse in Deuteronomy reads: "when brethren dwell together, and one of them dieth without children, the wife of the deceased shall not marry to another; but his brother shall take her, and raise up seed for his brother."76 This verse fit Henry's situation perfectly but because it contradicted the passages from Leviticus. Henry decided not to pay as much attention to it and regarded it as a Jewish law that the Jews no longer practiced and, thus, had no bearing on his situation. ${ }^{77}$

Henry focused on Leviticus 20:21 as his defense for seeking an annulment from Katherine. He claimed that because he married his brother's wife, God cursed their marriage and made it so that they never had any living sons. Robert Wakefield, a well known scholar at the time, worked with Henry in the formation of this argument. Together, they wrote many works explaining why the king's marriage was unlawful and against the will of God. However, Wakefield and Henry went a little further in their defense of the annulment, as they attacked the decision of the pope himself. Wakefield and Henry felt that the ability to grant the dispensation so Henry and Katherine could marry was not in the pope's power, as the marriage defied both divine and natural law because Katherine was the wife of Henry's brother first. ${ }^{78}$ Questioning the dispensation

\footnotetext{
75 Ibid.

${ }_{77}^{76}$ Bernard, The King's Reformation: Henry VIII and the Remaking of the English Church, 17-18.

77 Ibid.

78 Virginia Murphy, “The Literature and Propaganda of Henry VIII's First Divorce," in The Reign of Henry VIII: Politics, Policy, and Piety, ed., Diarmaid MacCulloch, 141.
} 
challenged papal authority and gave Henry his next option if his annulment was not granted based upon his scriptural defense. ${ }^{79}$

Henry and his councilors provided enough evidence that Pope Clement VII took interest and sent Cardinal Campeggio back to England to determine if the marriage was valid. When Campeggio arrived in England and met with the king, he urged Henry to reconsider the annulment and reconcile with his wife. When Henry refused to accept Campeggio's advice and made clear that he would not settle for anything less than an annulment, the idea that Katherine could retire to a convent began to circulate. Katherine, a pious woman, already embraced many of the practices of nuns of her time, such as hearing mass several times a day and spending hours alone in prayer. Cardinal Campeggio and Wolsey urged Katherine to consider entering a convent, but the queen refused. ${ }^{80}$ While her husband and his supporters at court cursed her for her obstinance, Katherine was loved by the people of England and her popular support encouraged her to refuse to accept a quiet retirement to a convent. ${ }^{81}$

Katherine's main concern was for the future of her daughter, Mary. She feared that if she retired to a convent, Anne Boleyn would convince the king to disinherit Mary and abandon her in favor of any children he had with Anne. Katherine may have lived like a nun, but she had already taken the vocation of a wife and intended to stay loyal to her choice. ${ }^{82}$ Katherine demanded that Henry take their case to the pope and to let him make the decision. She would not accept the judgment of anyone but the pope in this

\footnotetext{
${ }^{79}$ Bernard, The King's Reformation, 26.

${ }^{80}$ Ibid., 73.

${ }^{81}$ Ackroyd, Tudors, 51.

${ }^{82}$ Ibid.
} 
matter. ${ }^{83}$ Henry grew even angrier with his wife and began to make her life as miserable as possible. He forced Katherine away from court and refused to let her see their daughter. ${ }^{84}$ Katherine was exiled from court and sent to a remote estate to live out her days in isolation, unable to communicate with her daughter or Henry. ${ }^{85}$

Despite the number of scholars Henry had supporting the annulment, other scholars such as Thomas More, Reginald Pole, and Bishop of Rochester John Fisher supported the queen. More was one of the most prominent men in England who supported Katherine in the king's great matter. He maintained that the marriage was valid and refused to endorse any acts that said otherwise. Following his break with Rome, Henry passed a series of acts that intended to secure his authority as the head of the Church in England and ensure that his marriage to Anne was accepted. Henry's 1534 Act of Succession declared that his marriage to Anne Boleyn was valid and demanded allegiance to her and any heirs she provided Henry. More refused to accept this act because it would disinherit the Princess Mary and abandon Queen Katherine. More also refused to accept the Henry's 1534 Act of Supremacy that declared the king was the Supreme Head of the Church in England. More was a Catholic and respected the sanctity of marriage as well as the authority of the pope. More was executed for his refusal to obey the king's will and accept his new acts.

Reginald Pole wrote a book begging Henry to reconsider his break with Rome, called Defense of the Unity of the Church. After this text was published, Henry exiled Pole out of anger. Henry also had Pole's family arrested, including his elderly mother Margaret Pole, because their Plantagenet blood posed a threat to Henry's claim to the

\footnotetext{
${ }^{83}$ Bernard, The King's Reformation, 73.

84 Fletcher, The Divorce of Henry VIII: The Untold Story from inside the Vatican, 192.

85 Weir, Henry VIII: The King and His Court, 310.
} 
throne. ${ }^{86}$ Henry struck down those who opposed him, something else Henry's reign became known for. Henry's great matter was met with support from many but opposition from the people who had the power to make the final decision. Henry appealed to the pope but the pope was more inclined to please Katherine's nephew the Holy Roman Emperor, Charles V, who controlled most of Europe at this time. Despite months of debate and years of Henry wanting to end his marriage, the ecclesiastical courts ruled that their marriage was lawful. Henry's final option was to break with Rome.

Warham already spoke out against ending the marriage but when Henry began to make his move against the Roman Catholic Church, he spoke out again. Warham still had his authority as the Archbishop of Canterbury and used what influence he had to argue against the annulment. He had condemned it as a sin but his voice was still overshadowed by Wolsey's power at court. Many historians gloss over Warham in their studies of the beginning of the English Reformation, because he stepped down as lord chancellor and Wolsey became more influential at Henry's court. Warham, as Archbishop of Canterbury, still exercised considerable influence and his voice still mattered to Henry and much of England.

Weir, like other historians, describes the refusal of Warham to submit to the king's will toward the end of his life. Warham had quietly supported the king previously, but when Henry began to move against the church, Warham voiced his own protests regarding the king's threats against Rome. ${ }^{87}$ Warham spoke out against the king's mission to end his marriage and threatened to publicly condemn any legal action of the

\footnotetext{
${ }^{86}$ John Edwards, Archbishop Pole (Burlington, VT: Ashgate Publishing Company, 2014), 78-79.

${ }^{87}$ Bernard, The King's Reformation, 176.
} 
king's that could result in injury to the Church. ${ }^{88}$ Henry threatened him with the Statute of Praemunire if he carried out his threats to speak out against the king. The Statute of Praemunire was an act that would limit the powers of the papacy in England by bringing charges against the clergyman in question and trying him in an ecclesiastical court. If he was found guilty, he would lose all religious authority. However, Warham was never tried and he eventually submitted to Henry's wishes. ${ }^{89}$ By the spring of 1532, Warham ended his dispute with Henry through submission. Warham died on August 22, 1532 and Henry was free to appoint a new Archbishop of Canterbury, one who would act in his favor and who would never dare oppose him.

${ }^{88}$ Weir, Henry VIII: The King and His Court, 320.

${ }^{89}$ Bernard, The King's Reformation, 177. 


\section{CHAPTER 2 \\ THOMAS CRANMER AND HENRY VIII: THE BEGINNING OF CHANGE IN ENGLAND}

Henry chose Thomas Cranmer as Warham's successor. Cranmer was a different type of archbishop than Warham. He was a reformer and what was most important to Henry, he was sympathetic to the king's marital situation and the alterations Henry wanted to make to the Church in England. Henry needed men like Cranmer who would work for him and do what he asked without question. With Cranmer safely in place, Henry was confident that he could push forward with his annulment and that Anne Boleyn would be his queen. Examining the correspondence between Cranmer and Henry, as well as other members of court, shows how much the two men respected each other and how well they worked together.

The relationship between Henry and Cranmer was one that benefited both parties. Cranmer dedicated most of his career to helping Henry achieve his political and religious goals, including the break with Rome. Cranmer did not begin his career in the church as a reformer, but he slowly shifted his beliefs toward reform when he saw Henry moving further away from the pope. ${ }^{90}$ His changing attitude about reform in the Church was beneficial because of the alterations the Henrician government put in motion, such as the break with Rome. Cranmer's ideas about reform within the church grew over the course of his career at court, but he hid many of his more radical beliefs from Henry. Henry only wanted to take the reform to a certain point because he remained a Catholic in belief

90 Diarmaid MacCulloch, Thomas Cranmer: A Life (New Haven: Yale University Press, 1996), 29. 
and practice. Cranmer hid those beliefs he knew Henry would definitely disapprove of, such as altering the mass and openly favoring Protestant practices such as clerical marriage.

Cranmer and Henry grew close over the twenty years they worked together. Henry gave Cranmer the opportunity to build his career and elevate his position at court. As a result, Cranmer served Henry loyally. Because of Cranmer's loyalty, Henry was more lenient with Cranmer than he was with other men at his court. The two men respected one another and valued each other as friends until Henry's death in 1547. Their personal relationship affected the church because they embraced the separation of England and Rome but remained Catholic in many practices. The church was altered based on Henry's desires and Cranmer did the work to ensure the outcome pleased Henry. Cranmer was also able to lay the foundations for the reforms he would continue under Edward, which were too radical for Henry.

Henry VIII valued Cranmer not only for his loyalty but also for his education and knowledge of the Bible. At the age of fourteen, Cranmer entered Jesus College at Cambridge where he spent many years studying scripture under men who were against reform within the Church. ${ }^{91}$ Cranmer briefly left Cambridge after he got married around 1515-1516, but the marriage ended when his wife and child died in childbirth. ${ }^{92}$ Luckily for Cranmer, he was accepted back into Jesus College for his fellowship. Three years after returning to his fellowship, Cranmer took holy orders between $1519-1520 .{ }^{93}$

\footnotetext{
${ }^{91}$ Rev. John Edmund Cox, ed., Miscellaneous Writings and Letters of Thomas Cranmer, Archbishop of Canterbury, Martyr, 1556, vol. 2 of The Works of Thomas Cranmer, Archbishop of Canterbury, Martyr 1556 (Cambridge: Cambridge University Press, 1846), vii.

92 MacCulloch, Thomas Cranmer: A Life, 22.

${ }^{93}$ Ibid., 23.
} 
In spite of his later commitment to church reform, it would be a mistake to assume that Cranmer adopted Lutheranism and its ideas early in his career. ${ }^{94}$ Martin Luther published his 95 Theses in 1517 and they became a controversial topic discussed throughout the Roman Catholic Church and religious institutions throughout Christendom. ${ }^{95}$ Cranmer made it a point to study scripture and all the issues mentioned in the Lutheran controversy before he committed himself to one camp or the other. ${ }^{96}$ MacCulloch points out that Cranmer appeared to be on the more conservative side of the reform debate, aligning him with men such as Stephen Gardiner. ${ }^{97}$ Gardiner was part of Cardinal Wolsey's group that tried to find a way for the king to leave Katherine and was made Bishop of Winchester. Even though not much is known about Cranmer's time at Cambridge, MacCulloch is careful not to paint Cranmer as an immediate reformer but as an academic who slowly came around to the idea of reform. ${ }^{98}$

Cranmer remained loyal to the papacy in the early 1520 s. He was also somewhat supportive of reform but hostile toward Lutheranism. ${ }^{99}$ Bishop Fisher's work written in response to Luther's insolence against the papacy, Assertionis Lutheranae Confutatio, was one of the many works that Cranmer studied and used to understand both sides of the reform debate. Cranmer conceded that Luther had a point in regard to the church's not accepting the people's right to believe in what they want without it being considered a sin or heresy until the Council and pope declared otherwise. ${ }^{100}$ Fisher defended the papacy

\footnotetext{
${ }^{94}$ Ibid., 23-25.

${ }^{95}$ David H. Pill, The English Reformation 1529-58 (Totowa, NJ: Rowan and Littlefield, 1973), 38-39.

${ }^{96}$ MacCulloch, Thomas Cranmer, 23-29.

${ }^{97}$ Ibid., 25.

98 Ibid., 23.

${ }^{99}$ Ibid., 29.

100 Ibid.
} 
and Catholic practices and condemned Luther as a heretic. ${ }^{101}$ Cranmer thought that Luther was not completely wrong and understood that some aspects of the Church would have to be reformed if the institution was to survive. ${ }^{102}$ Cranmer knew there were flaws within the institution and could foresee clashes between the pope and the Councils of the Church but he still believed in the power of the church. By studying both sides of the argument and reading Luther's documents and books both supporting and condemning his ideas, Cranmer was able to form his own opinion. Cranmer began to have some doubts about the papacy and his acceptance of these doubts may be what gave him the strength to abandon "his papalist belief" by the early 1530 s. ${ }^{103}$

Cranmer defended the papacy against Luther but eventually he agreed with the growing hostility toward papal supremacy in England. ${ }^{104}$ His notes in the margins of certain texts, including works by Luther and Fisher's Confutatio, show his defense of the church. However, some of these notes show his more lenient and understanding state of mind than other papalists, or those who remained unshakably loyal to the pope. He saw problems within the institution, such as inefficiency of church councils, and but he still did not wholly agree with Luther and his ideas of reform. ${ }^{105}$

Henry had his own problems with the papacy and the amount of control it exercised over England and himself. For example, Henry disliked the fact that his loyalty to the papacy required that he not only give the church money but also that he defer to the judgment of the pope in his own personal matters, such as his first marriage. Henry determined that English ecclesiastical matters should be settled under English terms and

\footnotetext{
101 Ibid., 27-29.

102 Ibid., 23-29.

103 Ibid., 29.

104 Ibid.

105 Ibid.
} 
in English ecclesiastical courts instead of by the pope. ${ }^{106}$ The pope disliked those who interpreted scripture differently from him because it defied his papal authority. Papalists deferred to the pope for judgment on matters that involved religion because he was the heir to St. Peter chosen by God to interpret His will and lead the Roman Catholic Church. The pope was the principal authority of the Church and had the ability to make statements and decisions on interpretations of scriptural passages. ${ }^{107}$

Henry disliked deferring to anyone about anything, especially when it involved something he wanted. His deference to the papacy eroded as the decision about his marriage remained unresolved or contrary to what Henry wanted. ${ }^{108}$ Henry was a devout Catholic but his alienation from the pope stemmed from his personal desires to end his first marriage and marry Anne Boleyn. ${ }^{109}$ Henry looked for scholars and theologians to help him build a case to make the pope see things his way, or if that failed, to gather evidence to support England's ability to rule on religious matters without submitting to the pope. ${ }^{110}$ Cranmer was one of the scholars that Henry chose to employ in his case against Rome.

In 1527, Wolsey appointed Cranmer and other Cambridge dons to some minor diplomatic roles on a mission to Spain that same year. ${ }^{111}$ Cranmer proved himself to be a useful member of diplomatic entourages and did good work abroad for the king as a

\footnotetext{
${ }^{106}$ Pill cites Henry VIII and his indignation at Cardinal Wolsey for failing to use his authority as legate to rule in Henry's favor regarding his annulment. Pill notes the king's anger about Wolsey's lack of loyalty to the crown when he said that Wolsey was "bound by the most solemn obligation to pay due regard and respect to my royal dignity, my jurisdiction and my prerogative." Pill continues this passage by saying that "the royal authority over English ecclesiastics was once more being affirmed." Ibid., 52.

107 Ibid., 9-10.

${ }^{108}$ G.W. Bernard, The King's Reformation: Henry VIII and the Remaking of the English Church (New Haven: Yale University Press, 2005), 26.

${ }_{109}$ John Guy, Tudor England (Oxford: Oxford University Press, 1988), 116.

${ }_{111}^{110}$ Bernard, The King's Reformation: Henry VIII and the Remaking of the English Church, 26.

${ }^{111}$ MacCulloch, Thomas Cranmer, 33.
} 
diplomat in the court of Charles V. He performed so well in his diplomatic role that he was rewarded with a brief audience with King Henry. ${ }^{112}$ Cranmer was later sent to Italy and Germany as a delegate to the Holy Roman Emperor. After spending the better part of twenty-six years at Cambridge, aside from his diplomatic missions, Cranmer became involved in the discussion of the day: the King's annulment. Cranmer believed that the question could be solved through scripture, as did some of Henry's other advisors. After the attempt to find a technical error in the papal dispensation granted to Henry and Katherine in 1505 failed, Henry and his councilors looked to scripture for their solution.

Upon Cranmer's return from Spain he became one of the biggest advocates for the king's annulment. ${ }^{113}$ Cranmer saw this opportunity as a way to gain the king's favor and move up in the world. Cranmer did not appear ambitious on the surface, but his willingness to serve Henry showed that he was determined to gain some power and influence in the church and England. Henry hoped that having a man like Cranmer write in favor of the annulment, especially with his reputation for fairness amongst other scholars, would help sway others to Henry's cause.

For example, in the letter dated June 1531, Cranmer discussed the book written against the king seeking an annulment from Katherine by Cardinal Reginald Pole. Cardinal Pole, a cousin of King Henry, was a celebrated religious mind and future Archbishop of Canterbury. He was exiled from England after he wrote Defense of the Unity of the Church, which shamed Henry for his break with the Catholic Church and urged him to reconcile with the pope. Pole wrote that the king should leave the decision of his marriage to the care of the pope, but Cranmer disagreed because he felt that the

\footnotetext{
${ }^{112}$ Ibid., 36.

${ }^{113}$ Ibid.
} 
matter should be settled in England with no input from the pope. ${ }^{114}$ Cranmer respected Pole's work, as is evident in his letter to the Earl of Wiltshire, where he wrote, "he suadeth that with such goodly eloquence, both of words and sentence, that he were like to persuade many: but me he persuadeth in that point nothing at all. But in many other things he satisfieth me very well."115 This balance and ability to see both sides of an argument and calmly address the opposing side was one of the main reasons why Henry valued Cranmer and his counsel. ${ }^{116}$

When Cranmer and Henry met again in October 1529, Henry described his problem with his marriage, specifically how the immorality of it weighed on his conscience. He expressed his deep love for Katherine, but also his belief that he violated divine law by marrying his brother's widow. ${ }^{117}$ Henry felt that their marriage failed to produce a male heir because he married Katherine against the word of God. ${ }^{118}$ His fears abated when Princess Mary was born, but when Katherine still failed to produce a male heir the king's worries intensified. ${ }^{119}$ Henry's desire for a male heir drove him to see the flaw in his marriage. He needed a reason to get rid of his wife and her previous marriage to his brother became the perfect scapegoat.

As mentioned in the previous chapter, Henry and his advisors approached this problem with two possible solutions that he hoped would convince the pope to rule in his favor. The first of these solutions was to find a technical flaw in the dispensation that would render the document void. The second was to present an argument based on

\footnotetext{
${ }^{114}$ Cox, ed., Miscellaneous Writings and Letters of Thomas Cranmer, Archbishop of Canterbury, Martyr, $1556,229$.

${ }^{115}$ Ibid.

${ }_{116}$ MacCulloch, Thomas Cranmer, 54.

117 Bernard, The King's Reformation: Henry VIII and the Remaking of the English Church, 3.

118 Ibid.

119 Guy, Tudor England, 116-117.
} 
scripture to the pope. The king referred to two passages in Leviticus that forbade the marriage between a man and his brother's widow, one of which states that a coupling between a man and his brother's widow would not yield any children. ${ }^{120}$

The king wanted Cranmer to add his opinion to the defense of Henry's annulment from Katherine. Henry asked Cranmer to write an unbiased book about the royal marriage and whether or not the king was justified in his desire for an end to the union. Of course, the king would not have asked Cranmer to write this book unless he was certain that Cranmer's conclusion would support the king's wish for an annulment. ${ }^{121}$ Henry's recruitment of Cranmer to write this book shows that Henry disregarded the pope's dispensation and challenged papal authority. Henry felt that the pope could not have the power to make such a decision because according to scripture, Henry and Katherine's marriage violated natural and divine law. ${ }^{122}$ Thus, Henry questioned the divinity of the papacy and the pope's ability to speak for God. ${ }^{123}$

In his efforts to support Henry's annulment, Cranmer was not unaware of the consequences. In fact, Cranmer's relationship with the Boleyn family was also becoming closer. The Earl of Wiltshire, Anne Boleyn's father, was Cranmer's new patron when he began his book arguing for the end of the king's first marriage. ${ }^{124}$ Cranmer even wrote the book defending the royal annulment at Wiltshire's estate, Durham House. ${ }^{125}$ Cranmer also traveled as a part of Wiltshire's diplomatic party on his missions to the court of Charles V. His closeness to the Boleyns makes one wonder about the impartiality of

\footnotetext{
${ }^{120}$ Bernard, The King's Reformation, 17.

${ }^{121}$ MacCulloch, Thomas Cranmer, 45-46.

${ }^{122}$ Virginia Murphy, "The Literature and Propaganda of Henry VIII's First Divorce," in The Reign of Henry VIII: Politics, Policy, and Piety (New York: St. Martin's Press, 1995), ed., Diarmaid MacCulloch, 141.

${ }^{123}$ Bernard, The King's Reformation, 26.

${ }^{124}$ MacCulloch, Thomas Cranmer, 48.

${ }^{125}$ Ibid., 47.
} 
Cranmer's book. Cranmer expressed his sentiments about the repugnance of the king's first marriage in a letter written in June 1531 to Wiltshire. ${ }^{126}$

After Cranmer wrote his book about the king's marriage, the king sent him as a part of the Earl of Wiltshire's delegation to Italy to defend his book to the pope and attend the coronation of Charles V in $1530 .{ }^{127}$ While he was abroad, Cranmer was also tasked with visiting other universities throughout Europe to recruit more academic support for Henry's annulment. Henry trusted that Cranmer would find more support for his cause in the European universities and that with enough support the pope would have to accede to Henry's wishes. Henry and Wiltshire were uncomfortable with leaving the decision up to the pope who had strong ties with Charles V of Spain, the Holy Roman Emperor and nephew to Katherine. Henry feared that the pope would make this decision based not on theology but on the political environment of Europe. ${ }^{128}$ Henry gained a large amount of academic support from universities in Italy and France. ${ }^{129}$ G.W. Bernard states that Henry's desire for support from universities was prompted by the pope's inability to make an immediate decision about his annulment. ${ }^{130}$ It would be difficult to sway the pope to his side while the pope was so close with Charles V, but Henry was desperate.

The entire case hung on whether or not Katherine's marriage to Henry's brother, Arthur, was valid. If Katherine and Arthur consummated their marriage, then Henry had a reasonable chance of getting his annulment. ${ }^{131}$ Henry insisted that the marriage

\footnotetext{
${ }^{126}$ Cox, ed., Miscellaneous Writings and Letters of Thomas Cranmer, Archbishop of Canterbury, Martyr, $1556,229$.

${ }_{127}$ MacCulloch, Thomas Cranmer, 48.

${ }^{128}$ Guy, Tudor England, 117.

${ }^{129}$ G.W. Bernard, The King's Reformation, 19.

${ }^{130}$ Ibid.

${ }^{131}$ Ibid.
} 
between Katherine and Arthur had been consummated. However, Katherine maintained until her death that she remained a virgin until she married Henry. ${ }^{132}$ If the marriage had been consummated, then Henry could use the scriptural passages as validation for his annulment. But, without a confession from Katherine, the king still appeared to be stuck in his union.

In addition to his work as a diplomat, Cranmer was also doing other work for the king in the early 1530 s that laid the groundwork for the break with Rome. The royal committee of scholars, men appointed by Henry to gather information to support Henry's annulment and other theological matters, was gathering material in support of England breaking from the Roman Catholic Church. ${ }^{133}$ After Cardinal Campeggio did not rule in Henry's favor at the court at Blackfriars in the matter of his annulment, Henry tasked his group of scholars with establishing that historically the king was the figure who exercised "supreme jurisdiction of all descriptions within his realm." ${ }^{134}$ When Cranmer was not traveling throughout Europe, he assisted this committee of scholars. Cranmer's main responsibility was to decipher and edit the material of others into legible English. ${ }^{135}$ Cranmer became more involved in reformation politics in England as his political career and relationship with Henry progressed. Henry trusted Cranmer enough to place him amongst his scholars who worked to show that the king held supreme control over matters in England. Cranmer's work as one of the editors for this collection of

\footnotetext{
${ }^{132}$ Peter Ackroyd, Tudors: The History of England from Henry VIII to Elizabeth I (New York: Thomas Dunne Books, 2012), 53.

${ }_{133}$ MacCulloch, Thomas Cranmer, 54-55.

${ }^{134}$ Ibid., 55.

${ }^{135}$ Ibid., 54.
} 
documents gave him the experience he needed to complete his Book of Common Prayer in the future. ${ }^{136}$

During one of Cranmer's trips abroad, Archbishop Warham died. Warham's death presented an opportunity for the king to appoint an ally as archbishop. Cranmer was not the most experienced nor distinguished clergyman at Henry's court, but he had proven himself useful to the king in the quest for an annulment. He was chosen to be the next archbishop despite the presence of more qualified candidates at court, such as Bishop Gardiner who was a consecrated bishop. Cranmer was not chosen solely because of credentials, but also because he had the support of the Boleyns. Thanks to Anne, the Boleyn family had the ear of the king in almost every matter at English court. ${ }^{137}$ Cranmer earned support because he had shown himself to be loyal to the king and the Boleyns rather than the papacy. Henry knew that Cranmer would not question his motives, but that he would follow Henry's wishes. In Henry's mind, Cranmer was an ideal candidate for the See of Canterbury.

In 1533, Henry appointed Cranmer as his next Archbishop of Canterbury so that Cranmer could implement Henry's annulment and proclaim Anne Boleyn, whom the king secretly married, his lawful wife. ${ }^{138}$ Even as the Roman Catholic Church approved Cranmer to office, Cranmer himself was moving further towards church reform and Protestantism. While visiting Nuremberg in 1532, Cranmer chose to remarry, though he was still a member of the clergy. ${ }^{139}$ Cranmer had not shown much favor toward Protestantism, until he got married while he was a member of the clergy. In England and

\footnotetext{
136 Ibid.

${ }^{137}$ Ackroyd, Tudors: The History of England from Henry VIII to Elizabeth I, 50.

${ }^{138}$ Ibid., 72.

${ }^{139}$ MacCulloch, Thomas Cranmer, 69.
} 
throughout most of Europe, clergymen were not permitted to marry. Places where clergymen could marry included the states that accepted Protestant reforms and rejected the Catholic requirement of celibate clergymen. Despite Cranmer's lack of public commitment to Protestantism, by choosing to marry, Cranmer allied himself to reform within the Church. ${ }^{140}$

Clergymen famously had mistresses throughout this time period. For example, it was well known throughout England and parts of Europe that Wolsey had a live-in mistress and illegitimate children. ${ }^{141}$ Even though few people knew about Cranmer's marriage, it was shocking once it came to light. Because Cranmer accepted control of the most religious position in England, he could not publicly admit his marriage, at least not yet. He risked the loss of Henry's trust and his livelihood if anyone discovered his marriage. If he had remained a simple priest, he risked much less by marrying. Cranmer kept his new wife a secret for many years. Henry did not learn of the marriage until 1543. ${ }^{142}$ However, because Henry had so much affection and respect for Cranmer, he was lenient on him and allowed Cranmer's wife and their children to enter England, although they still remained hidden from court. ${ }^{143}$

Cranmer felt a sacred duty to obey and serve Henry as best he could. He returned to England once he received word that the king demanded his return to court, although he seemed to take his time. ${ }^{144}$ MacCulloch argues that the timing of his marriage and sudden appointment to the highest religious office in England explain Cranmer's

\footnotetext{
${ }^{140}$ Ibid., 69-71.

${ }_{141}^{141}$ Alison Weir, Henry VIII: The King and His Court (New York: Ballentine Books, 2001), 330.

${ }^{142}$ Guy, Tudor England, 181.

143 Ibid.

${ }^{144}$ MacCulloch, Thomas Cranmer, 77.
} 
reluctance to hastily return to England. ${ }^{145}$ Because Cranmer's marriage as a clergyman was illegal in England, he was uncertain how to deal with his new circumstances. Cranmer decided it was best for all involved if he did not mention his marriage and accept his king's demand that he return to England.

When Cranmer returned to England in January 1533, he learned that Henry had married Anne Boleyn in secret, and that she was also pregnant. ${ }^{146}$ Henry no longer respected his marriage to Katherine and he and Anne decided that they could not continue to wait for Rome's decision on the validity of the king's first marriage. Henry was confident in the verdict, but he was going to get rid of Katherine with or without the approval of the pope. Cranmer previously collaborated with Edward Foxe and other men to determine that Henry was capable of making decisions on religious matters without the support or permission of the papacy. ${ }^{147}$ Henry's scholars maintained that England should not have to defer to Rome about decisions that affected England. Once Cranmer officially became Archbishop of Canterbury, he and Henry set out to make England selfsufficient in all religious matters. The pope provided a bull confirming Cranmer's appointment as archbishop but Cranmer refused to declare his loyalty to Rome and instead "declared that he was determined to fulfill only his obligations to God and to the king." 148

Cranmer's correspondence with men such as the Earl of Wiltshire, Thomas Cromwell, and King Henry all reflect how devoted Cranmer was to pleasing Henry and doing what the king asked of him. On April 11, 1533, Cranmer wrote that the king's

\footnotetext{
${ }^{145}$ Ibid.

${ }^{146}$ Ibid., 83.

${ }^{147}$ MacCulloch, Thomas Cranmer: A Life, 54.

${ }^{148}$ Ackroyd, Tudors: The History of England from Henry VIII to Elizabeth I, 74.
} 
great matter was the talk of Christendom, but that few were as well versed in the subject as Cranmer and remained ignorant in the finer details, of which only God could truly judge. ${ }^{149}$ Cranmer also wrote about his new duties and loyalty to the king, "that where the office and duty of the archbishop of Canterbury, by your and your progenitors' sufferance and grants, is to direct, order, judge, and determine causes spiritual in this your grace's realm. .." ${ }^{\prime 150}$ Cranmer continued, "and because I would be right loth, and also it shall not become me, forasmuch as your grace is my prince and sovereign, to enterprise any part of my office in said weighty cause touching your highness, without your grace's favour and licence obtained in that behalf. .."151 After these pronouncements of the duty of the office of archbishop and Cranmer's loyalty to the king, Cranmer continued that he, with the king's permission, would pass a final judgment about the king's first marriage. In these statements, one can see that Cranmer respected that Henry was in charge of the Church and that no decision would be made without his approval.

Once Cranmer was consecrated as archbishop, he decreed that Katherine's appeal to Rome on the matter of her marriage was illegal and Rome had no jurisdiction over this matter, based on the newly passed Act in Restraint of Appeals. ${ }^{152}$ Cranmer proceeded to exercise his new powers to ensure that no one, especially priests who supported Katherine's cause, spoke against the decree that the king's first marriage was no longer valid. ${ }^{153}$ A few days before Anne's coronation, Cranmer officially ruled that Katherine and her first husband, Prince Arthur, consummated their marriage, which made

\footnotetext{
${ }^{149}$ Cox, ed., Miscellaneous Writings and Letters of Thomas Cranmer, Archbishop of Canterbury, Martyr, $1556,237$.

${ }^{150}$ Ibid.

${ }^{151}$ Ibid.

${ }^{152}$ MacCulloch, Thomas Cranmer, 89.

${ }^{153}$ Ibid.
} 
Katherine's marriage to Henry illegal and invalid according to scripture. ${ }^{154}$ Cranmer presided over Anne's coronation ceremony and was seated at the Queen's table during her coronation feast. ${ }^{155}$

The next step was to establish that England had the right to rule itself in religious matters and did not have to defer to the pope in Rome. Pope Clement VII was enraged by Henry's disobedience. Clement provisionally excommunicated Henry and his advisors in July $1533 .{ }^{156}$ Even though he was not specifically mentioned, Cranmer was one of those included in the excommunication order. The pope's condition was that if Henry set Anne aside and allowed Katherine to resume her place at his side, then the pope would allow Henry to return to the fold. ${ }^{157}$ Guy states that "Foxe and Cranmer had redefined the boundaries between royal and ecclesiastical power, arguing that, ever since the conversion of the Anglo-Saxons to Christianity, the kings of England had enjoyed secular imperium and spiritual supremacy, like the later Roman emperors." ${ }^{158}$ In addition, "the English church had always been a separate province of Christendom subject only to royal jurisdiction. Even the papacy had (allegedly) confirmed this." ${ }^{, 159}$

Over the next few months, Henry and Parliament, guided by Thomas Cromwell, passed several laws that included the Act of Appeals and the Act of Supremacy, both of which legitimized Henry's power and nullified any power Rome had in England. ${ }^{160}$ The most important of these acts was the Act of Supremacy, passed in 1534. It stated that "the King our sovereign lord, his heirs and successors kings of this realm, shall be taken,

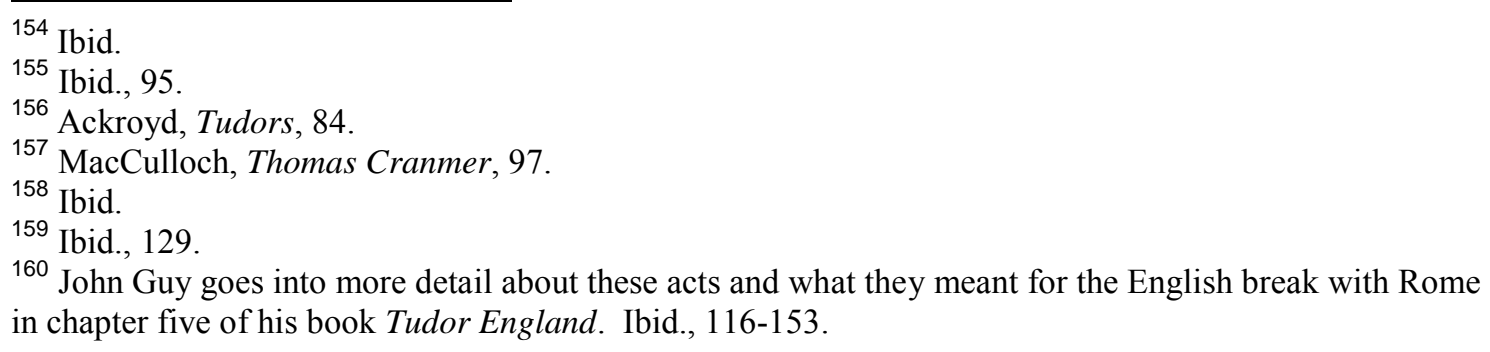


accepted and reputed the only supreme head in earth of the Church of England called Anglicana Ecclesia," and in addition will enjoy all the privileges and authority that belong to the head of the Church of England. ${ }^{161}$ Another act that addressed the new role of the Church in England that Henry passed was the Act Extinguishing the Authority of the Bishop in Rome, in 1536. This act made the "exercise or defense of the papal authority" in England illegal. ${ }^{162}$

After his marriage and his subsequent appointment as archbishop, Cranmer began to see the value of a reformed England. Cranmer supported the king's annulment and his marriage to Anne Boleyn. He also supported the king's break from Rome and worked for years helping other scholars find a way to legitimize England's jurisdiction over its religious matters. In his letters to the king, Cranmer expressed his devotion to the king and assured him of his willingness to do his bidding.

However, a few short years later when Anne Boleyn fell from the king's favor, Cranmer altered his view of the queen. Anne Boleyn and the king courted for years during Henry's first marriage and were secretly married after Anne became pregnant. Anne gave birth to one living child during her three year marriage to the king, the king's second daughter, Elizabeth. Any other pregnancies Anne had ended in miscarriages or still births, including the miscarriage of one son. ${ }^{163}$ The king became unhappy with Anne and looked to end this marriage. Henry accused Anne of adultery, incest, and witchcraft,

\footnotetext{
${ }^{161}$ Ibid., 135.

162 Ibid., 136.

${ }^{163}$ Ackroyd, Tudors, 92.
} 
all of which she was found guilty of in a trial held in the spring of $1536 .^{164}$ The day after Anne's execution, Henry married Jane Seymour. ${ }^{165}$

In a letter dated May 3, 1536, Cranmer wrote to the king of Anne's disgrace. He stated, "I am in such a perplexity, that my mind is clean amazed; for I never had better opinion in woman, than I had in her; which maketh me to think, that she should not be culpable. And again, I think your highness would not have gone so far, except she had surely been culpable." ${ }^{166}$ Cranmer did not say anything to suggest that he supported Anne in her case but he did ask the king to forgive him for his sympathies toward her. Cranmer felt that next to the king he "was most bound to unto her of all living creatures."167 Cranmer refused to see Anne as guilty until she was proven to be so, in which case not even God could save her. This shows Cranmer's sense of selfpreservation and how he always allied himself with the king. Cranmer knew that the king had made up his mind regarding the queen. Cranmer meant what he wrote when he said that Anne must have done what the king accused her of for Henry to react as he did.

Cranmer remained loyal to the king above all others. In July 1536, Parliament passed the Act Extinguishing the Authority of the Bishop in Rome. ${ }^{168}$ Cranmer wrote of his approval of the new act and described two of his sermons that stated the inability of the pope to control England. The letter specified three different topics that related to the pope and the doctrine that the office promoted that no longer applied in England.

Cranmer stated that the king commanded that people throughout his realm "that they with

\footnotetext{
${ }^{164}$ For more on the fall of Anne Boleyn refer to: Alison Weir, The Lady in the Tower: The Fall of Anne Boleyn (New York: Ballantine Books, 2010).

${ }^{165}$ Ackroyd, Tudors, 97.

${ }^{166}$ Cox, ed., Miscellaneous Writings and Letters of Thomas Cranmer, Archbishop of Canterbury, Martyr, 1556, 324.

${ }^{167}$ Ibid.

${ }^{168}$ Guy, Tudor England, 136.
} 
all acceleration and expedition should do their diligence every one in his diocese, fully to persuade your people of the bishop of Rome his authority, that it is but a false and unjust usurpation, and that your grace, of very right and by God's law, is the supreme head of this church of England, next immediately unto God."169

The first of the three topics that Cranmer discussed in his sermons were the methods through which the bishop of Rome usurped his authority. Cranmer stated that he began his declaration "that the bishop of Rome was not God's vicar in earth." ${ }^{170} \mathrm{He}$ continued with the statement that even though "it was taught these three or four hundred years, yet it was done by means of the bishop of Rome, who compelled men by oaths so to teach, to the maintenance of his authority, contrary to God's word."171 Second, Cranmer claimed that there was no holiness in the papal office in Rome, but that it merely claimed a holy title. ${ }^{172}$ Third, Cranmer spoke "against the bishop of Rome' his laws; which he calleth "divinas leges," and "sacros canones," and maketh them equal to God's laws. And here I declared that many of his laws were contrary to God's laws." ${ }^{173}$ He stated that some of the laws were not false but that they claimed to have some kind of holy authority where none existed, such as a remission of sins if people observed the laws. ${ }^{174} \mathrm{He}$ also emphasized that the laws of Henry's realm should always be observed for they were in place to make the realm a better place and safe for all. ${ }^{175}$

Another topic Cranmer covered in this letter was his feeling toward Rome and how it differed from that of a prior he met, who preached a sermon that contradicted

\footnotetext{
${ }^{169}$ Cox, ed., Miscellaneous Writings and Letters of Thomas Cranmer, Archbishop of Canterbury, Martyr, $1556,326$.

${ }^{170}$ Ibid.

171 Ibid.

${ }^{172}$ Ibid.

173 Ibid.

174 Ibid.

175 Ibid., 326-7.
} 
Cranmer's. The words of the prior that Cranmer discussed were treason, thanks to the Act of Supremacy passed in 1534. The Act was enforced by the Treason Act which stated that it was treason to threaten the royal family and also that it was treason to call the king any of the following: "a heretic, schismatic, tyrant, infidel, or usurper."176 Cranmer told the king that this man committed treason and heresy and that he should be put on trial and examined. ${ }^{177}$ It is clear in this letter that Cranmer's loyalty to the papacy was at an end and that he only recognized the king and God as his authorities. Following Anne Boleyn's trial and execution, some of the pope's supporters in England began to make themselves known, thinking that since Anne was gone, the king would return to the fold of Rome ${ }^{178}$ However, the king was adamant in his separation from Rome and over the next few years he and Thomas Cromwell dismantled the monasteries and redirected all the taxes that used to go to the pope's coffers into the royal treasury. ${ }^{179}$

Cranmer remained quietly by Henry's side throughout all the changes and upheaval of the first years of the Anglican Church. He appointed men who would support him and exercised his influence over the religious environment in England at this time. He helped spearhead missions to Lutheran princes to establish alliances with England. In 1534, Parliament passed the Act of Dispensations, which ended any payments to Rome and gave Cranmer the power to give out dispensations, or "licenses to

\footnotetext{
${ }_{177}^{176}$ Guy, Tudor England, 136.

177 Cox, ed., Miscellaneous Writings and Letters of Thomas Cranmer, Archbishop of Canterbury, Martyr, 1556,328 .

178 Ibid., 328 n.

${ }^{179}$ Eamon Duffy goes into details about the destruction of the different religious institutions that Henry destroyed and stole their wealth in The Stripping of the Altars: Traditional Religion and in England c. 1400-1580 (New Haven: Yale University Press, 1992).
} 
allow departures from the canon law." ${ }^{180}$ Cranmer had more power in England than any other religious figure, aside from the king. ${ }^{181}$

While Cromwell was the more important political figure and involved in many of the most famous events during the Reformation, such as the dissolution of the religious houses, Cranmer corresponded with Cromwell regarding the problems of the day. They discussed a multitude of things from the appointment of new gentlemen to the king to reporting illegal behavior within the religious community that violated Henry's newly passed laws. $^{182}$

When Queen Anne and Cromwell both fell out of favor and were executed, Cranmer remained by Henry's side and even though both events upset him. When he wrote to the king of Anne's supposed disgrace, the tone of the letter is pained. He remained the king's "faithful subject" and "most humble subject" because he knew if he turned against the king or if the king thought Cranmer had turned against the monarchy, he could have met the same fate as Cromwell and Anne Boleyn. ${ }^{183}$ Cranmer understood how delicate the king's favor was and he did all he could to avoid losing that favor.

Cranmer also wrote to the king about Cromwell's treason in June 1540.

Cromwell surpassed what Henry envisioned for England during its Reformation and was accused of being a Protestant, a group Henry opposed. ${ }^{184}$ Cranmer played a key role in the reformation and defined much of the king's ideology that formed the foundation of Henry's Reformation. Cromwell directed most of the king's propaganda and his

\footnotetext{
${ }^{180}$ A.G. Dickens, The English Reformation (New York: Schocken Books, 1964), 119.

${ }^{181}$ For more on Henry VIII's religious policies see: Bernard, G.W. "The Making of Religious Policy, 1533-1546: Henry VIII and the Search for the Middle Way." The Historical Journal 41 (June 1988): 321 349.

182 Ibid., 334.

${ }^{183}$ Ibid., 324.

${ }^{184}$ Guy, Tudor England, 179.
} 
campaign to dissolve the monasteries and other religious houses, and Cranmer had no real part in any of this. Cromwell was already unpopular with the king after his failed marriage arrangement with Anne of Cleves, and when Cromwell grew too aggressive with his reform policies, he was accused of peddling Protestantism and arrested on suspicion of treason and heresy. ${ }^{185}$

Cranmer expressed his deep shock and disbelief at Cromwell's treason in his letter to the king, dated June 14, 1540. Cranmer stated that he "loved him as my friend, for so I took him to be; but I chiefly loved him for the love which I thought I saw him bear ever towards your grace, singularly above all."186 Even though Cranmer stated that he loved Cromwell, he qualified the statement when he wrote that "if he be a traitor, I am sorry that I ever loved him or trusted him, and I am very glad that his treason is discovered in time. .."187 Cranmer wrote, "Buy yet again I am very sorrowful; for who shall your grace trust hereafter, if you might not trust him?"188 He turns his grief about Cromwell into grief for the king and reiterates his own loyalty to the king and offered his prayers to the king that he may find a worthy advisor soon. ${ }^{189}$

Henry loaned Cranmer money and also allowed Cranmer to express his doubts about the religious doctrine regarding transubstantiation, the changing of the wine and

\footnotetext{
${ }^{185}$ Cromwell arranged an alliance with Cleves, a Protestant state, through a marriage between Henry and Anne of Cleves in 1539. Henry had the marriage annulled because he claimed he could not consummate the marriage because she was so ugly. The match did not please Henry and he annulled the marriage but retained Anne of Cleves at court as his legal sister and gave her Hever Castle, the birthplace of Anne Boleyn, to live in. More information can be found in Antonia Fraser's book, The Wives of Henry VIII (New York: Vintage Books, 1992).

${ }^{186}$ Cox, ed., Miscellaneous Writings and Letters of Thomas Cranmer, Archbishop of Canterbury, Martyr, $1556,401$.

187 Ibid.

188 Ibid.

${ }^{189}$ Ibid.
} 
bread at communion into the body and blood of Christ. ${ }^{190}$ Henry rewarded Cranmer's loyalty with leniency in many matters, such as Cranmer's marriage before his appointment as archbishop and accusations of his support of the Reformation. When Cranmer was accused by his enemies, namely Bishop Gardiner, of promoting the Reformation within the diocese of Canterbury, Henry was not angry with him. Instead, he allowed Cranmer to look into the matter himself and investigate the charges brought against him. ${ }^{191}$ Cranmer explored reform within the church but he did so quietly, in order to avoid angering the king. Cranmer was a reformer, but it was not until Edward VI's reign that he converted to full Protestantism.

Cranmer and Henry's relationship was an interesting one. Cranmer rarely took liberties with his position and always showed that his loyalty to the king came above everything else. Henry respected Cranmer's scholarship and his academic way of looking at problems and finding solutions favorable to the king, such as with the divorce from Katherine and his break with Rome. Guy claims that "it was his unassuming manner as much as his belief that Scripture justified the royal supremacy that assured his special relationship with Henry VIII." ${ }^{192}$

Cranmer remained by Henry's side throughout the rest of his reign and acted on the king's behalf, granting dispensations and acting as a councilor to the king. Cranmer put his loyalty to the king above everything else and the king valued that loyalty. Both Henry and Cranmer benefited from their relationship and they used what the other had to offer to advance their own ideas, with the key difference being that Cranmer was much more subtle about his agenda than Henry. This relationship with Henry and the king's

\footnotetext{
${ }^{190}$ Guy, Tudor England, 180-1.

${ }^{191}$ Ibid., 195.

${ }^{192}$ Ibid., 181.
} 
leniency afforded Cranmer the opportunity to build a more solid foundation for reform, which he would orchestrate under Henry's son and heir, Edward VI.

Their relationship affected the status of the church in England because the church embraced some of Cranmer's changes while also remaining mostly Catholic in practice as Henry wanted. Henry wanted to keep the church as it was as much as possible, just without papal authority. England was still not a Protestant country, but it was no longer affiliated with the papacy. Henry did not want to make England a Protestant country but he no longer wanted to defer to the pope in matters of religion. Cranmer accepted this and worked with Henry to achieve this goal. Henry and Cranmer's personal relationship had an impact on the church in England because without their foundation of respect, Henry would not have allowed Cranmer to have as much power as he did and Cranmer would not have been able to implement some of his reforms that formed the foundation for the next step in reformation under Henry's son, Edward VI. 


\section{CHAPTER 3}

\section{CRANMER AND EDWARD VI: CONTINUING THE REFORMATION}

Thomas Cranmer and Henry VIII had a mutual respect that benefited both men. Henry and Cranmer worked together to rid England of papal supremacy and place the monarch in charge of the church in England. Henry requested that the archbishop be by his side in the hours before his death and though he lost the power of speech, he and Cranmer held hands in the final moments of the king's life. ${ }^{193}$ Cranmer mourned the death of the king but Henry's passing also marked an opportunity for Cranmer to completely embrace reform in England. Cranmer and Henry became close friends over the years, but Cranmer hid many things from the king. Cranmer waited more than ten years to disclose to the king that he was married and more importantly, he kept his true religious beliefs to himself for fear the king might take offense. Henry's death was a great loss to Cranmer but it also represented freedom to the reformist archbishop. ${ }^{194}$ Cranmer joined forces with the men who led the regency council of King Edward VI, men who happened to heavily favor Protestant reform. Cranmer and the new regency council used their authority to continue England's journey toward Protestantism.

When Henry died in 1547, his nine year old son, Edward VI, ascended to the throne of England, which now carried with it the title of Supreme Head of the Church of England. Cranmer and Edward corresponded throughout the boy king's life. Henry named Cranmer as Edward's godfather, so Cranmer kept in touch with the boy to ensure

\footnotetext{
${ }^{193}$ Diarmaid MacCulloch, Thomas Cranmer: A Life (New Haven: Yale University Press, 1996), 360.

${ }^{194}$ Ibid., 361.
} 
his well-being. Cranmer also served as one of Edward's tutors and wrote him letters full of praise for his accomplishments. When Edward became king, Cranmer encouraged Edward to lead his people to salvation and drew comparisons between Edward and King Josiah, a biblical king who lived in the seventh century BCE and ascended to the throne of Judah at a young age. Josiah was a good example for Cranmer to use to inspire Edward to reform the church because Josiah was responsible for reforming religion during his reign, despite his youth. ${ }^{195}$ Before his death, Henry named in his will certain individuals he wished to serve on his son's regency council. Henry nominated Cranmer to the council, where Cranmer served as one of Edward's advisors. Because Edward was so young, Cranmer and some members of Edward's regency council were able to influence him to continue the reformation that began under his father. Even though Henry did not want to take the reforms in the Church of England any further, Cranmer encouraged Edward to finish the work his father started. ${ }^{196}$ Cranmer imparted his reformist ideas to Edward and charged the boy with leading England to salvation. Their personal relationship changed the Church of England. Through Cranmer's influence and guidance, along with the regency council, Edward completed his own reformation of the Church in England and made it into a Protestant institution.

Before his death, Henry set a plan in motion for his succession. The Third Act of Succession (1544) both set the framework for Edward's regency and legitimized Mary and Elizabeth as Edward's heirs, if he died childless. ${ }^{197}$ The Act also stated that if Henry should die before Edward came of age, then Henry would appoint a regency council in

\footnotetext{
${ }^{195}$ Ibid., 365.

${ }^{196}$ Rev. John Edmund Cox, ed., Miscellaneous Writings and Letters of Thomas Cranmer, Archbishop of Canterbury, Martyr, 1556, vol. 2 of The Works of Thomas Cranmer, Archbishop of Canterbury, Martyr 1556 (Cambridge: Cambridge University Press, 1846), 413.

197 John Guy, Tudor England (Oxford: Oxford University Press, 1988), 196.
} 
his last will and testament. ${ }^{198}$ This news brought about factions all vying for control of the regency council and the power of ruling the country in the young king's place. One of the factions included the Howard family, led by the Duke of Norfolk, Anne Boleyn and Catherine Howard's uncle, and Bishop Gardiner. ${ }^{199}$ This faction had little chance of gaining Henry's favor again after the Catherine Howard's betrayal and execution. Catherine, Henry's fifth wife, was beheaded for adultery and treason in 1542 after less than two years as queen. ${ }^{200}$ The second faction was a "powerful coalition" that included the Earl of Hertford, John Dudley, Viscount Lisle, William Parr, and William Herbert. ${ }^{201}$ These men, led by Hertford were eventually successful in their quest to control the regency council, with Hertford being named Lord Protector. ${ }^{202}$ Hertford was Edward's maternal uncle and aligned himself with other men who closely attended the king in his last year of his life. ${ }^{203}$

Shortly before Henry's death, Hertford and his companions altered the king's will so they would benefit from the death of the monarch. They gave the regency council "full power and authority" during Edward's youth. ${ }^{204}$ After Henry died on January 28, 1547, Hertford seized Edward and the king's assets and put them all in the Tower of London, thus ensuring his faction's victory. ${ }^{205}$ Hertford then named himself the Duke of

198 Ibid.

199 Ibid.

${ }^{200}$ For more on Catherine Howard see: Antonia Fraser, The Wives of Henry VIII (New York: Vintage Books, 1992), 308-354.

${ }^{201}$ Guy, Tudor England, 197.

202 Ibid., 196-7.

203 "Lisle, Herbert, Denny, Paget, and Thomas Seymour surrounded the king." Guy continues to describe how men in Hertford's "coalition" surrounded the king and were charged some of the most important tasks, including signing state papers for the king. Guy explains how Henry did not sign any documents for the last year of his life but instead used a "secret 'dry stamp." Hertford and his companions controlled the king's signet seal and his signature. Ibid., 197-8.

204 Ibid., 198-9.

${ }^{205}$ Guy goes into more detail about Hertford's scheme to gain control of the regency in chapter 7 of his book, Tudor England. Ibid., 199. 
Somerset and became Lord Protector Somerset, in addition to granting other members of his faction titles and wealth. ${ }^{206}$ Somerset arrested those who opposed him, including the Duke of Norfolk. On January 31, 1547, Parliament officially named Hertford the Lord Protector and granted him governorship of King Edward VI. ${ }^{207}$ Soon after Parliament named Hertford Lord Protector, he overturned the king's will and he took it upon himself to appoint anyone he desired to the regency council for young King Edward. ${ }^{208}$

The regency council, led by the newly appointed Duke of Somerset, was sympathetic to Protestantism. Catherine Parr, the last wife of Henry VIII, was supportive of the Protestant cause and the religious faction gained more popularity in England, at least among the aristocracy who could benefit from the Roman Catholic Church being undermined in England. During Henry's reign, the king dismantled many Catholic institutions, including convents and monasteries, and took the wealth from churches for the royal treasury. Those aristocrats who proved themselves loyal to Henry were allowed to purchase some of the property formerly owned by the church, provided they also paid the taxes on it. Henry knew a Protestant cell existed within his royal court, but he was unaware of the extent of its influence. ${ }^{209}$ Henry established committees to investigate the suspected Protestants but some of the most influential Protestants were those who were closest to Henry's person, including some of the men Henry designated to tutor his children. ${ }^{210}$ The regency council, including Cranmer, and their growing affection for Protestantism trickled down to King Edward. Cranmer had already shown a preference

\footnotetext{
${ }^{206}$ Ibid.

${ }^{207}$ Ibid.

${ }^{208}$ For more on Henry VIII's last will and testament see the following article by Lacey Baldwin Smith. Smith, Lacey Baldwin. "The Last Will and Testament of Henry VIII: A Question of Perspective." Journal of British Studies 2 (November 1962): 14-27.

${ }_{210}^{209}$ Guy, Tudor England, 196.

${ }^{210}$ Ibid.
} 
for some Protestant ideas, such as clerical marriage, and reforming Catholic doctrine through his work under Henry. Under Edward, he could continue the reforms that he began under Henry.

As mentioned in the previous chapter, Cranmer already allowed that the Roman Catholic Church was not perfect and had room to improve but until Henry was so inclined, he did not want to do away with the institution entirely. Henry remained Catholic in practice until his death, but he refused to acknowledge the pope in Rome as his superior. Henry referred to the pope as the Bishop in Rome, allowing that he had the same religious authority as any other bishop, but that he had no jurisdiction in England. Cranmer had his opinions about Protestantism, but he followed Henry's lead when it came to expressing his opinions openly. For example, it was not until after Henry died and Edward officially ascended to the throne, that Cranmer publicly proclaimed his marriage and lived openly with his wife and children. ${ }^{211}$

It was not only his beliefs about clerical marriage that Cranmer began to openly admit, but also his reformist views. Cranmer was a reformer at Henry's court, and after Henry's death he aligned himself with the Lord Protector and was a member of the young king's regency council. Cranmer encouraged Edward to accept the Protestant faith and to expel Catholicism and the papacy from England altogether. ${ }^{212}$ Cranmer compared Edward to the young King Josiah in hopes of inspiring the boy to live up to the example of Josiah. Cranmer stated at Edward's coronation, "Your majesty is God's vice-gerent and Christ's vicar within your own dominions, and to see, with your predecessor Josiah, God truly worshipped, and idolatry destroyed, the tyranny of the bishops of Rome

\footnotetext{
${ }^{211}$ MacCulloch, Thomas Cranmer: A Life, 361.

${ }^{212}$ Ibid., 365.
} 
banished from your subjects, and images removed."213 Cranmer encouraged the young king to continue the reformation started by his father and to complete the task of removing all the influence of Rome from England.

Cranmer and Edward corresponded before Edward became king. Edward was a precocious child who excelled in his studies and impressed his tutors with his ability to learn. In a letter, dated January 13, 1544, Edward wrote to Cranmer to express his gratitude for the archbishop's fatherly attention and "godly and wholesome advice."214 Edward was around six years old when he composed this letter in Latin, no doubt under the supervision of his tutors. Historians praise the young monarch for his ability to learn and retain information including mastering languages, such as Latin and Greek. ${ }^{215} \mathrm{He}$ took a particular interest in religion and his tutors favored Protestantism over Catholicism. $^{216}$

His tutors were Sir John Cheke, a renowned classist, and Richard Cox, future Bishop of Ely under Elizabeth. ${ }^{217}$ Both men were a part of Catherine Parr's inner circle, which was suspected to favor reform and Protestantism. ${ }^{218}$ Their association with her may be part of the reason why they were appointed to tutor young Edward. While it is unclear if Cheke and Cox set out to influence their young ward before he became king, Edward was more than willing to pick up the mantle of King Josiah and continue the religious reform of his country. Edward's favoritism toward Protestantism is documented from the time he took the throne as is the fact that he was not easily manipulated by

\footnotetext{
${ }^{213}$ Cox, ed., Miscellaneous Writings and Letters of Thomas Cranmer, Archbishop of Canterbury, Martyr, $1556,127$.

214 The letter is recorded in this volume in Latin and then translated into English below. Ibid., 413.

215 Diarmaid MacCulloch, The Boy King: Edward VI and the Protestant Reformation (New York: Palgrave, 2001), 20-21.

${ }^{216}$ A.G. Dickens, The English Reformation (New York: Schocken Books, 1964), 193-4.

217 Ibid.

${ }^{218}$ Guy, Tudor England, 195-6.
} 
anyone except for Protestant politicians. ${ }^{219}$ Edward was quick to adopt the new religion and "became a passionate Protestant, bigoted and intolerant." $220 \mathrm{He}$ favored long sermons that were typical of Protestant preachers and often wrote notes while listening to these long sermons. Edward's intelligence was evident from a young age and his ability to take notes on sermons in Greek was just one of the many things that showed his precociousness. Cranmer repeatedly acknowledged Edward's piety and his dedication to the study of theology in their correspondence and praised the young king's knowledge and devotion to his faith. Cranmer used his influence over Edward to encourage him to lead England to an age of reform, free of all influence from Rome. Cranmer encouraged Edward to continue in his studies so he "may hereafter illuminate the whole of your realm of England.",221

It is not surprising that Edward grew to favor Protestantism when those closest to him favored Protestant reform. When he was born, his father had already separated from Rome and there was little hope for a reconciliation. His mother's family, particularly his uncle Lord Protector Somerset, favored Protestant reform and the profits he could yield from it, such as collecting some of the religious taxes that used to go to the papacy but now went to the crown. Protestant reform and ideas were what Edward grew up learning and understanding. None of those closest to him were Catholic, except for his oldest half-sister, Mary. Edward and his council, including Cranmer, wrote to Mary demanding that she discontinue holding Catholic mass in her household and accept the reforms that

\footnotetext{
${ }^{219}$ Dickens, The English Reformation, 194.

220 Alison Weir, The Children of Henry VIII (New York: Ballantine Books, 2008), 32.

${ }^{221}$ The letter is recorded in this volume in latin and then translated into English below. Cox, ed., Miscellaneous Writings and Letters of Thomas Cranmer, Archbishop of Canterbury, Martyr, 1556 , 413.
} 
were being practiced throughout England. ${ }^{222}$ Edward was driven to complete his mission of reform and follow the lead of his council.

In another letter, Cranmer explained that Edward needed to continue the work of his father and complete the Reformation in England. The letter is undated but based on the information in the letter, it is likely from 1547, the first year of Edward's reign. In the letter, Cranmer proclaimed that God intended for Edward to complete the work of his father who began the reformation in England. ${ }^{223}$ Cranmer omitted the fact that Henry did not want the reform to go any further. Cranmer then stated that "perceiving that your majesty, by the advice of your most dear uncle my lord protector, and the rest of your grace's most honorable council, is most desirous perfectly to finish and bring to pass that your father did most godly begin," in reference to the reformation that Henry began in the 1530s with his break from Rome. ${ }^{224}$ Cranmer offered his services to help Edward, but he placed the majority for the responsibility of bringing the true word of God to the people of England in the hands of the young king. Cranmer stated, "the youth of your grace's realm may learn to know God, and how they may most purely and sincerely honor, glorify, and serve him, and may also learn their office and duty how they ought to behave themselves," and that his older subjects "may, by hearing of their children, learn in their age that which passed them in their youth. ${ }^{, 225}$ Cranmer told Edward he would be there by his side and professed his belief to all of England at Edward's coronation that Edward was the new Josiah who would usher in an era of reform to England. ${ }^{226}$

\footnotetext{
222 Ibid., 526-530.

${ }^{223}$ Ibid., 419.

224 Ibid.

225 Ibid., 420.

${ }^{226}$ Ibid., 419-420.
} 
Cranmer took advantage of Edward's age and trusting attitude. He used the memory of Henry VIII, the father who fractured his ties with Rome to beget a son, to encourage Edward to continue the reformation. Under Edward, Cranmer could finally publish his book of homilies and mandate that a copy be distributed to every church in England. ${ }^{227}$ Cranmer began this project under Henry in 1542 but it was not until 1547 that the book was produced and issued throughout England. ${ }^{228}$ Cranmer's most famous publication also came out during Edward's reign, the Book of Common Prayer, in 1549. The Book of Common Prayer is the text that formed the base for religious services in the reformed church of England and helped establish religious uniformity throughout the country. It was required to be in all the parishes in England and includes the calendar, morning and evening prayers, Gospels, psalms, and many more important religious texts. ${ }^{229}$ Cranmer was also able to legalize clerical marriage under Edward, something he never would have been able to do under Henry, despite Henry's lack of ire at the discovery of Cranmer's marriage. ${ }^{230}$ Cranmer took full advantage of the fact that Edward and the rest of his regency council supported Protestant reform.

Many of the courtiers and members of the regency council supported continuing the reformation. Lord Protector Somerset saw reforming the church as an opportunity for providing the crown with more money to support the extravagance of the Tudor court as well as for his own personal gain. ${ }^{231}$ Somerset led the regency council and often carried out many of his plans without the consent of his fellow council members. The council

\footnotetext{
${ }^{227}$ MacCulloch, Thomas Cranmer, 372.

${ }^{228}$ Ibid.

${ }^{229}$ Colin Buchanan, Historical Dictionary of Anglicanism (Lanham, MD: Scarecrow Press, INC., 2006), 65.

${ }^{230}$ For more on the status of clerical marriage under Edward and Henry see the following article. Yost, John K. "The Reformation Defense of Clerical Marriage is the Reigns of Henry VIII and Edward VI." Church History 50 (June 1981): 152-165.

${ }^{231}$ David H. Pill, The English Reformation 1529-58 (Totowa, NJ: Rowan and Littlefield, 1973) 121.
} 
was supposed to function with all sixteen members having a voice. Somerset, however, had a different agenda and went about things his own way. He seized numerous religious houses and property for his own, including a country house built from a nunnery in Middlesex. ${ }^{232}$ Cranmer had the goal of creating a reformed England. The rest of the councilors were dedicated to bringing that government and church to fruition, even if it was only to gain more wealth through the destruction of the Catholic faith in England. Cranmer and Somerset set out early on in the reign of Edward to continue the Reformation and establish Protestantism as the religion in England.

Cranmer corresponded for many years with many of his fellow members of Edward's regency council, including Lord Lisle and William Cecil. He also addressed letters to the entire council. In his letters to Lisle, dated 1539 and years before Edward came to the throne, some of the details include the new proclamations from Cromwell, such as placing Bibles in every parish throughout England and placing certain priests in Lisle's parish. ${ }^{233}$ Cranmer's letters to Lisle often had to do with the new religious policies put in place by Cromwell's government before Cromwell was executed in 1540 .

Cranmer also corresponded with William Cecil, who served in Somerset's household until 1549, as one of the king's councilors in 1550, and eventually as Elizabeth's chief advisor. Cecil and Cranmer discussed many subjects, but the tone of the letters suggests that these men were good friends. In one letter, Cranmer thanked Cecil for admonishing him for being covetous in the past. ${ }^{234}$ In another letter, dated 25 August 1552, Cranmer discussed the appointment of new archbishops in Ireland. He

\footnotetext{
${ }^{232}$ Weir, The Children of Henry VIII, 35.

${ }^{233}$ Cox, ed., Miscellaneous Writings and Letters of Thomas Cranmer, Archbishop of Canterbury, Martyr, $1556,390-1$.

${ }^{234}$ Ibid., 437.
} 
noted that he had some candidates but that it would be difficult to persuade any of them to accept the post due to the changes within the church. ${ }^{235}$

One letter, dated 26 August 1552, discussed the printing of The Book of Common Prayer, arguably the greatest achievement of Edward's reign and Cranmer's career. During Edward's reign, Cranmer published many works including a Book of Homilies and The Book of Common Prayer. The Book of Homilies was a collection of sermons that Cranmer assembled and distributed throughout the parishes of England. He also ensured that each parish had in its possession an English Bible and a copy of Paraphrases of Erasmus in English. ${ }^{236}$ While they added religious texts in English to each parish, the council also removed anything that was considered idolatrous, including wall paintings, statues, and any objects that promoted what they saw as superstitions of Roman Catholicism. ${ }^{237}$

Throughout Henry's reign, the religious practices remained largely Catholic despite the split from Rome. However, once Henry died, Cranmer and the rest of the council set out to alter the church and continue their reformation according to their ideas about reform. Many were still chiefly motivated by the chance to become wealthier, but Cranmer was more motivated by the theology and his own beliefs about reform.

Cranmer restructured the mass, with the approval of the other council members, and published The Book of Common Prayer in 1549. The Act of Uniformity, passed in March of 1549, ruled that the services in The Book of Common Prayer published by Cranmer were to be used in all churches throughout England. ${ }^{238}$

\footnotetext{
${ }^{235}$ Ibid., 438.

${ }^{236}$ Pill, The English Reformation 1529-58, 126.

237 Ibid., 130.

${ }^{238}$ MacCulloch, Thomas Cranmer, 408.
} 
Eventually, it would be illegal for any priest to celebrate mass according to the Roman Catholic practice or to include any Catholic "superstitions" within their service, such as discussion of the cult of saints or mention of purgatory. ${ }^{239}$ The offending priest would be fined or imprisoned depending on how long he continued resisting the Act of Uniformity. Rebellions rose up throughout the country in reaction to the changes in the church and Somerset was imprisoned when his position at court weakened. ${ }^{240}$ These rebellions were exactly what Henry hoped to avoid during his reign when he reformed the church in England. He split from Rome but kept most of the doctrine and practices as they were in order to keep to his own beliefs, but also to avoid insurrection from his people. In Somerset's absence, John Dudley, Earl of Warwick, controlled the council and refused to allow Somerset to regain control once his release was secured. Somerset was executed for treason in January 1552 and Dudley, now the Duke of Northumberland, remained in control for a time. ${ }^{241}$

Cranmer, Edward, and the regency council worked to continue the Reformation in England and supplied works such as the Book of Homilies and two editions of the Book of Common Prayer (1549 and 1552). During this time, Parliament also passed many acts that promoted the end of Roman Catholic influence in England, including allowing clerical marriage and revision of canon law. ${ }^{242}$ Whatever the motivation of the council members, their goal was the same as Cranmer's: the completion of the reformation in England. Cranmer wrote many texts throughout Edward's reign to promote the reformation. His Forty-Two Articles of Religion critiqued the Catholic practices and

\footnotetext{
${ }^{239}$ Weir, The Children of Henry VIII, 81.

${ }^{240}$ Pill, The English Reformation, 142-145.

${ }^{241}$ MacCulloch, The Boy King: Edward VI and the Protestant Reformation, 99.

${ }^{242}$ MacCulloch, Thomas Cranmer, 377.
} 
praised the reformed practices. They eventually became the basis for the Thirty-Nine Articles published under Elizabeth I. ${ }^{243}$

Cranmer was able to accomplish all these tasks in the Edwardian Reformation due to his relationship with Edward and the rest of the council members. They all agreed that completing the Reformation in England was the best option for England. Cranmer had a strong relationship with Edward and the boy listened to Cranmer's advice throughout his short life. Cranmer and his relationship with Edward shaped the Anglican Church during Edward's reign because they implemented many reform policies and ideas that Cranmer helped create and endorsed. Edward practiced Protestantism and Cranmer supported reforms in the church and together they reformed the Church in England to Protestant standards.

When the king died in 1553, Cranmer and the council's reform efforts were destroyed with the accession of Mary. But while they had the chance, they changed the face of religion in England. Some of the changes they made were reinstated once Elizabeth succeeded in 1558. However, none of it could have been accomplished without Edward's devotion to reform and Cranmer and the council's determination to complete the reformation. These goals were held together by the mentorship of Cranmer over Edward and his ability to work with his fellow council members during the short reign of Edward.

${ }^{243}$ Guy, Tudor England, 224-225. 
CHPATER 4

REGINALD POLE AND MARY I: RETURNING ENGLAND TO CATHOLICISM

When King Edward VI died, his older sister, Mary was the next heir to throne according to Henry VIII's Third Act of Succession. Once she defeated an attempt to put Lady Jane Grey on the throne, Mary took her place as Queen of England. ${ }^{244}$ Her goal from the beginning of her reign was to return England to the Catholicism she knew in her childhood, before England broke with Rome. However, it was not an easy mission and Mary relied on her counselors, her husband, and most importantly, her archbishop Reginald Pole, to help her bring about the restoration of England to papal authority in Rome.

To accomplish her goal of returning England to Catholicism, Mary had to install someone she could trust as the Archbishop of Canterbury. Unfortunately for Mary, Thomas Cranmer still held the office. Mary had held Cranmer in contempt ever since her youth and she knew she could not trust him. He was the man responsible for the annulment of Mary's parents' marriage and the loss of her inheritance. She never recovered from the loss of her mother, who was taken from her while she was still a teenager. Her relationship with her father also never rebounded to what it was before Anne Boleyn came into the picture.

\footnotetext{
${ }^{244}$ Peter Ackroyd goes into more detail about the brief rule of Lady Jane Grey in his book, Tudors: The History of England from Henry VIII to Elizabeth I. In chapter 21, entitled "The Nine-Day Queen," Ackroyd discusses the coup that brought Lady Jane Grey to the throne, how Mary and her supporters foiled the attempted treason, and finally how Mary came to control the throne. Peter Ackroyd, Tudors: The History of England from Henry VIII to Elizabeth I (New York: Thomas Dunne Books, 2012), 235-244.
} 
This chapter will show through an examination of their correspondence that Mary and her archbishop, Reginald Pole, developed a strong personal relationship because they were both dedicated to restoring the Catholic Church in England. After acting as papal legate to England, Pole accepted Mary's invitation to become her next Archbishop of Canterbury. Together they would undo what the Henrician and Edwardian governments had done, from the break with Rome to the dismantling of the monasteries. Pole and Mary worked well together to achieve these goals and Pole often acted as not only a counselor to Mary but also a confidant. Pole sought to advise Mary in religious matters and he also helped her deal with her own personal problems. While Mary did not always heed Pole's advice, she always respected his counsel.

Their goal--to return England to Catholicism and the fold of Rome--united the two and they worked tirelessly to complete their mission. They not only had a strong working relationship but also a personal relationship and truly valued one another. Their relationship and how well they worked together was the most influential factor in shaping the church in England during Mary's reign. Their relationship was the reason why the church in England restored its papal connection and the other Catholic traditions that were abolished by Edward and Henry. The foundation Mary and Pole built could have achieved their goal of returning England to Catholicism, but when Mary and Pole died, their work remained unfinished and was dismantled by Elizabeth. Mary and Pole remained close until their deaths, on November 17, 1558.

Mary's first task was to meet with Parliament and pass a law that officially legitimized her as an heir to Henry VIII and another that repealed the religious legislation 
passed during Edward's reign. Next, she set out to reorganize the Church in England. ${ }^{245}$ Henry VIII broke from the Roman Catholic Church and began the Church of England in the 1530s. Edward VI and his councilors continued the Reformation in England and fully embraced Protestantism in England. One of Mary's biggest obstacles was Archbishop Cranmer.

Mary imprisoned many of the men who supported the ascendency of Lady Jane Grey. Cranmer, however, was not among those arrested at this time. Mary did not arrest him right away because he held the office of Archbishop of Canterbury, an office Mary still respected despite its Protestant occupant. She even allowed Cranmer to preside over her brother's funeral. ${ }^{246}$ Mary refused to see Cranmer and despite the fact that she let him officiate her brother's funeral, she did not plan to allow him to continue leading the Church in England. Mary quickly reintroduced the Catholic mass in England and by early September 1553, Cranmer issued a public statement detailing his disdain for the Catholic mass, hoping to rally support. ${ }^{247}$ He had this declaration printed and widely circulated throughout London. ${ }^{248}$ After this publication came out, Cranmer was summoned before the privy council and it was decided that in addition to his treason against the queen, his blatant disrespect and heretical writings merited his arrest and imprisonment in the Tower. ${ }^{249}$ Though he was not executed right away, Cranmer was declared legally dead and lost his See at Canterbury. ${ }^{250}$ In September 1555, Cranmer's

\footnotetext{
245 Judith M. Richards, Mary Tudor (London: Routledge, 2008), 139.

${ }^{246}$ Ibid., 131.

247 Ibid., 132.

${ }^{248}$ Linda Porter, The First Queen of England: the Myth of "Bloody Mary" (New York: St. Martin's Press, 2008), 353.

${ }^{249}$ Ibid.

${ }^{250}$ Diarmaid MacCulloch, Thomas Cranmer: A Life (New Haven: Yale University Press, 1996), 554-555.
} 
heresy trial began and once his guilt was established, he was executed on March 21, 1556 after he recanted his Protestant beliefs. ${ }^{251}$

Mary's council came together quickly following Edward's death. Mary was careful to choose men whom she felt she could trust, but also men she knew would support her and the religious changes she intended to make. Some of the men she chose were already members of her household, such as Robert Rochester. ${ }^{252}$ Another member of her council was Sir John Huddleston, who protected Mary from the Duke of Northumberland when she fled from her home at Hunsdon during her brother's reign. ${ }^{253}$ Some of Edward's council members wrote to Mary seeking a position at her court, including William Paget, who served under Henry and Edward. Mary accepted some of Edward's former councilors, especially if they were experienced in matters of state, such as Paget. ${ }^{254}$ One of the first tasks Mary and her council accomplished was the removal of bishops who were likely to oppose Mary's religious plans for England. Mary and her government passed an ecclesiastical act that removed any deans, bishops, and ministers from their office if they were appointed during the previous two reigns and their predecessor was still living. ${ }^{255}$ This was all part of Mary's effort to cleanse the church in England and return it to what it was before her father broke with Rome.

Mary's vision for England and its religious future was to attain something similar to what was being practiced in Spain at this time. Spain still followed the pope but religious leaders in Spain enacted their own reforms before the Council of Trent. Their reforms included expelling Muslims and Jews from Spain and purifying Catholicism in

\footnotetext{
${ }^{251}$ Porter, The First Queen of England: the Myth of “Bloody Mary," 357.

${ }^{252}$ Richards, Mary Tudor, 125.

${ }^{253}$ Ibid.

${ }^{254}$ Ibid.

${ }^{255}$ David H. Pill, The English Reformation 1529-58 (Totowa, NJ: Rowan and Littlefield, 1973), 169.
} 
Spain. $^{256}$ Mary wanted to institute practices similar to those in Spain because of her family connection with the Spanish monarch: her cousin was Emperor Charles V who was king of Spain as well as Holy Roman Emperor. She maintained a relationship with him throughout her life, especially during her years of difficulty under her father and Edward. Charles even schemed to extricate her from England and give her sanctuary in Spain when her life was threatened in England. ${ }^{257}$ While many in England were not opposed to returning to their former faith, they were not keen to accept the papacy or any outsider as another ruler, particularly a Spanish ruler. ${ }^{258}$ Mary needed help to establish her ideas and begin her counter reformation. She found allies in her future husband, Philip II of Spain, and Cardinal Pole.

Cardinal Pole was destined for the Church from an early age by his mother, Margaret Pole. Margaret Pole was one of the last of the Plantagenets; her father was George, Duke of Clarence, brother to both King Edward IV and Richard III. She had six children by the time of her husband's death in 1504 and her financial situation was not stable enough to support her entire family. According to John Edwards, it was not only a devotion to religion but also pressure from their economic situation that prompted Margaret to send her son, Reginald, into the Church. ${ }^{259}$ It was not uncommon for younger members of large families to enter the Church in this time because often the inheritance was left to the eldest son. Pole attended Magdalen College, Oxford with

\footnotetext{
${ }^{256}$ For more on the Spanish Inquisition see: Green, Toby. Inquisition: The Reign of Fear. New York: Thomas Dunne Books, 2007.

${ }^{257}$ Richards, Mary Tudor, 98.

258 Ibid., 144-146.

259 John Edwards, Archbishop Pole (Burlington, VT: Ashgate Publishing Company, 2014), 8.
} 
support from King Henry VIII. ${ }^{260}$ By 1521 , Pole was on his way to Italy, again with the support of Henry VIII, to continue his studies.

Over the next twenty years, Pole and Henry's relationship altered. Pole began his career in Italy as Henry's devoted servant and even recruited Parisian theologians to Henry's side during the king's struggle to annul his marriage to Katherine of Aragon. However, Pole's position with Henry changed in the 1530s when Henry pushed forward with his divorce from Katherine without support from Rome. Initially, Pole sided with Henry in regards to the divorce but by 1531, Pole changed his mind and opposed the king's annulment. ${ }^{261}$ According to Edwards, Pole only supported the divorce in order to avoid disputes regarding the English succession. ${ }^{262}$ For him, as for many in the England, the memory of the Wars of the Roses was still fresh, having ended only a few decades earlier. But when Pole saw how far Henry was willing to go to achieve his divorce he decided he could no longer remain quiet, especially if Henry meant to break with Rome.

The relationship fractured further when Henry broke with Rome and in 1536 Pole published his work condemning the split, De Unitate Ecclesiastica or On the Unity of the Church. In this work, Pole beseeched Henry to recant his split with Rome and repent for his sin of usurping papal authority in England. Pole reprimanded Henry for the split and for entertaining the idea that a king could become the supreme head of the church. Pole summarized this argument to Henry when he stated, "I have endeavored to show that this function belongs to the Roman pontiffs, the successors of Peter."263 Pole's evidence

\footnotetext{
260 Ibid., 9.

${ }^{261}$ Edwards acknowledges that Pole's new opposition on the royal divorce is based on second hand knowledge but that he wrote down his opinion soon after rumors of his hostility to the divorce circulated throughout Henry's court. Ibid., 41.

262 Ibid.

263 Reginald Pole and Joseph G. Dwyer, translator, Defense of the Unity of the Church (Westminster: Newman Press, 1965), 175.
} 
included "the authority of Sacred Scripture, the testimony of the holy fathers, the habit and customs of our predecessors, and by the general agreement of the whole Church now long since established through many ages." ${ }^{264}$ Pole stated that he wrote this work to convince Henry of his errors and to help the king to find his way back to salvation. Pole's work failed to sway Henry. In fact, Pole's book angered Henry so much that he exiled Pole from England. ${ }^{265}$ Despite this failure to convince Henry to recant, Pole continued to rise through the ranks of the Catholic Church and he was made cardinal by Pope Paul III in December $1536 .{ }^{266}$

After Pole and Henry VIII's relationship came to an end, Pole remained in Italy and travelled throughout Europe with the goal of uniting other Christian princes to bring England back to the fold of Rome. ${ }^{267}$ Pole became a valuable member of the College of Cardinals under Pope Paul III and was named a papal legate, a representative of the pope in foreign countries. As legate he visited the court of Emperor Charles V, but did not return to England until the 1550s. Pole remained a legate to England but he was not very influential during the reigns of Henry and Edward due to their determination to remain separated from Rome. Also, under Henry Parliament passed an act of attainder that forbade Pole from entering England. If Pole were to be caught in England he would be arrested and possibly executed, as much of family was in 1538 and through the early $1540 s^{268}$

\footnotetext{
${ }^{264}$ Ibid.

265 John Guy, Tudor England (Oxford: Oxford University Press, 1988), 235.

${ }^{266}$ G.R. Elton, Reform and Reformation: England, 1509-1558 (Cambridge, MA: Harvard University Press, 1977), 259.

${ }^{267}$ Edwards, Archbishop Pole, 76-82.

${ }^{268}$ Ibid., 78-79.
} 
Pole continued to ascend through the Church hierarchy and used his power to express his ideas about reforming the Catholic Church. He agreed with Martin Luther that the church had some problems and he sought to fix them internally after he became a cardinal. ${ }^{269}$ In 1542, Pope Paul III decided to form a council in Trent to address potential reforms within the Catholic Church. Some of the problems addressed at the Council of Trent, included the question of the pope's primacy in the church and the belief that the church needed to be cleansed of all heresy and corruption. ${ }^{270}$ In 1545, Pole was among the legates appointed to the Council of Trent by Paul III and he wrote De Concilio, which addressed the purpose and ideas of the ensuing council. ${ }^{271}$

Pole was dedicated to the Church and its attempts to reform during the 1540s and 1550s. He wrote about reform and played an important role in the reformation culture in Catholic Europe through his work during the Council of Trent. After the death of Henry VIII in 1547, Pole saw an opportunity to resume his activities in England. He began to correspond with Lord Protector Somerset but he was still not welcome back in England as long as he wanted to repair the relationship between England and the Roman Catholic Church. When Pole began a dialogue with his home country, he realized he wanted nothing more than to bring it back within the fold of the Roman Catholic Church. ${ }^{272}$

When Mary came to throne, the leaders of the Catholic Church saw the opportunity to secure their position in England once again. Pole was appointed papal legate to England under Pope Julius III with the power "to reconcile all heretics, and

\footnotetext{
${ }^{269}$ Ibid., 85.

${ }^{270}$ Ibid., 105-106.

271 Ibid., 105.

272 Thomas F. Mayer, The Correspondence of Reginald Pole, A Calendar, 1547-1554: A Power in Rome, vol. 2 of The Correspondence of Reginald Pole (Aldershot, England: Ashgate Publishing Limited, 2003), 129.
} 
others who were penitent after the schism, to remove the canonical penalties that they had received during the break with Rome, and absolve even those whose cases would otherwise have been reserved for the pope., ${ }^{273}$ Julius III charged Pole with correcting all the wrongs committed in England during its Protestant period. ${ }^{274}$ Mary and Pole had the same goals when it came to restoring England to what they felt was the true religion. ${ }^{275}$ There is no record of Mary and Pole writing to one another before she became queen. Their common goal of restoring the true religion was what united them and helped them forge a strong relationship. Pope Julius III wrote to Pole on August 5, 1553, and informed Pole that he would become the next legate to England and that he was to return England to Roman Catholicism. ${ }^{276}$ The pope wrote two more letters dated that day with instructions about how Pole should proceed as legate, such as who should be granted dispensations. ${ }^{277}$ In a letter dated August 7, 1553, Pole stated that Mary's accession to the throne was "a big victory for God's goodness, even through a woman.",278 $\mathrm{He}$ continued his letter with acknowledgement of Mary's years of tragedy throughout her life but also that "through her piety and obedience will be restored." 279

Pole congratulated Mary on her accession and also informed her of his position as legate to England. ${ }^{280}$ Throughout his letters, Pole wrote that it must have been God's will that Mary came to the throne after all the tragedy she suffered during her life. Pole also

\footnotetext{
273 Ibid., 121.

${ }^{274}$ Ibid., 121-22.

${ }^{275}$ For more on the priorities of the Marian Government see: Pogson, Rex H. "Reginald Pole and the Priorities of Government in Mary Tudor's Church." The Historical Journal 18 (March 1975): 3-20.

${ }^{276}$ Mayer, The Correspondence of Reginald Pole, A Calendar, 1547-1554: A Power in Rome, vol. 2 of The Correspondence of Reginald Pole, 129.

${ }^{277}$ Ibid. 129-133.

${ }^{278}$ Ibid., 137.

${ }^{279}$ Ibid.

${ }^{280}$ Ibid., 163 .
} 
wrote to remind her that it was her duty to restore the true religion to her country. ${ }^{281} \mathrm{He}$ urged her to remember how the evil of Protestantism first came to England, "the divorce, first from your mother, and much worse from the Church."282 He also stated in this letter that God wanted Mary “restored without anyone's assistance, not the pope's, the emperor's, not prince's, nor mine. He treated you like his elect, schooling you in adversity until He could use you to plant a better root."283 Pole wanted to make it clear that Mary owed her life and her throne to God and no one else. Due to their lack of relationship prior to Mary's ascension to the throne, this may have been Pole's way of apologizing and also currying favor with the new queen. Through these statements, Pole was also setting himself up as a bridge between Mary and the pope.

Pole also stated that he "must let you [Mary] know what obedience to the Church means. ${ }^{284}$ He said that her father forsook the obedience to the Church to pursue his own desires. Through this letter, Pole asserted himself not only as the pope's legate but also as Mary's instructor and mentor. Pole counted on her religious devotion to ensure her loyalty not only to himself but to the pope, whom he represented. He was well aware of her piety, as he cited it many times in letters to Julius III and Mary herself, but he felt she had more to learn as a ruler responsible for the salvation of her country.

Pole also warned Mary about listening to others in regards to how she should rule her kingdom, especially Charles V. Charles had supported Mary as the heir to the throne of England and acted as her protector. ${ }^{285}$ He wanted England to be under his control and, for the time being, he had Mary's ear. He did his best to deter her from allowing Pole to

\footnotetext{
281 Ibid., 161-163.

282 Ibid., 163.

283 Ibid.

284 Ibid.

${ }^{285}$ Richards, Mary Tudor, 84.
} 
enter England, at least until after she married his son, Philip II. Their marriage was more important to the emperor than the restoration of the Catholic Church in England, which was Pole's top priority. ${ }^{286}$ In a letter dated October 2, 1553, before Mary's first parliament was held, Pole advised Mary to address the issues with primacy in her first parliament and to "reform all injustices of the past governors" and establish "good order for the future. ${ }^{, 287}$ During her first parliament, Mary oversaw the reversal of the legislation put into place by her brother's government, confirmed the validity of her parents' marriage and officially legitimized herself in the process. ${ }^{288}$

Mary was the first Queen of England in her own right so it is no surprise that she leaned on the experience of the men around her. She knew she was inexperienced and she came to rely on men like Pole and, eventually, her husband Philip II to help her make decisions. However, Pole had a more vested interest in the well-being of England than Charles V or Philip II. So much had changed in England following Pole's exile from England under Henry. Pole saw it as his personal mission to help Mary bring England back into the fold of Rome and to restore the Catholic institutions in England.

One of the first tasks Mary and her councilors undertook to bring back Catholicism to England was to reintroduce the Catholic mass in churches. ${ }^{289}$ One of the trademarks of the Protestant reforms in England was to hold mass in the local vernacular instead of in Latin. However, the Catholic Church still mandated that mass be presented in Latin, as it had been for centuries. Reintroducing the Catholic mass was one thing, but next Mary had to reconcile her people to the papacy. This proved to be a difficult task

\footnotetext{
286 Ibid., 129.

${ }^{287}$ Mayer, The Correspondence of Reginald Pole, A Calendar, 1547-1554: A Power in Rome, vol. 2 of The Correspondence of Reginald Pole, 208.

288 Richards, Mary Tudor, 139-40.

289 Ibid., 131.
} 
because many, such as Thomas Wyatt, in England did not want the pope to intervene in their lives and rebelled against it. ${ }^{290}$ It was this fear of the return of papal authority that inspired the Wyatt Rebellion. ${ }^{291}$ Many in England saw the pope as an outsider. The people did not trust the papacy to reign supreme over the church in England because they feared being subjected to foreign laws. The delay in Pole's arrival to England can be attributed to Charles V's agenda that conflicted with Pole's, Mary's impending marriage to Philip II of Spain, and her fear that welcoming a papal legate would cause further uproar in England. ${ }^{292}$

The Wyatt Rebellion, another plot to overthrow Mary, came about when a group of Protestant lords hoped to replace Mary with Elizabeth and avoid the reinstitution of Catholicism and the papacy in England. After some of the men who lead the rebellion against Mary were found out or fled the country, Thomas Wyatt was the only man left who was willing to act against the queen. ${ }^{293}$ Wyatt led a small force against the queen. He claimed he did not want to hurt the queen, only to replace her council. Wyatt, like many other men in England, opposed Mary marrying Philip of Spain because he feared Philip would come to rule England, if not as king then through his wife. ${ }^{294}$ The Wyatt

\footnotetext{
290 Ibid.

291 Ibid., 149.

292 Edwards and other authors, such as David Pill, write that Pole advised Mary to remain unmarried instead of accepting a foreign marriage treaty with Philip II of Spain. Mary trusted Emperor Charles V, her cousin, because they stayed in contact over the years that her father and brother persecuted her. She trusted his counsel because he was family and she never knew anything but kindness from him. However, Pole also wrote to Charles that it may have been partially Charles's fault for the loss of papal authority in England in the first place because he so staunchly defended his aunt, Katherine of Aragon, when Henry VIII sought to annul their marriage. Edwards, Archbishop Pole, 125-130.

293 Richards, Mary Tudor, 151.

294 Ibid.
} 
Rebellion failed and Wyatt and his co-conspirators were convicted of and executed for treason. $^{295}$

This rebellion gave Pole cause to reiterate that Mary should openly proclaim obedience to the Catholic Church. Pole wrote to Mary on February 15, 1554, that it was "clear that tyranny came from disunion and disobedience. Deposed by God's hand. Now defeat of rebels a reminder that you did not understand first message: obedience the foundation of just government. ${ }^{296}$ Mary was still reluctant to bring Pole to England and realign with Rome but Pole was adamant that she should set an example of obedience for her people to follow.

In a letter dated October 8, 1553, Mary wrote to Pole about her first parliament. She informed him that "this parliament will abolish all these statutes, which have been the origin of our plagues." ${ }^{297}$ However, in this letter she did not bid him to come to England and in another letter, dated October 28, 1553, Mary told Pole that his "legation [was] 'hateful to our subjects' and must be delayed. More trouble about the pope than about true religion." ${ }^{298}$ While Mary approved of Pole becoming papal legate to England, she did not want to derail her reign and alienate herself from her people by welcoming a papal official into her country before the people were ready.

Mary not only deferred to the wills of the men around her but she was also subservient to the Church and discussed this obedience in her letter dated October 28, 1553. She wrote to Pole about bringing back the "old religion" but noted that her people

\footnotetext{
${ }^{295}$ For more information on the role religion played in the Wyatt Rebellion see Malcolm R. Thorp's article, "Religion and the Wyatt Rebellion of 1554." Thorp, Malcolm R. "Religion and the Wyatt Rebellion of 1554." Church History 47 (December 1978): 363-380.

${ }^{296}$ Mayer, The Correspondence of Reginald Pole, A Calendar, 1547-1554: A Power in Rome, vol. 2 of The Correspondence of Reginald Pole, 266.

${ }^{297}$ Ibid., 210.

${ }^{298}$ Ibid., 222.
} 
were still not comfortable with accepting the papacy as an outside governing body. ${ }^{299}$ She wrote that there was some trouble with the acceptance of the pope as head of the church after so many years of the monarch holding that position. But Mary was uncomfortable accepting a title she felt did not belong to her. She wrote to Pole, "[I] have always preferred the 'old religion', and cannot accept the title against my conscience and my sex, so asked for its suspension." ${ }^{, 300}$ In this letter, Mary also asked for Pole's "very prudent council," showing how much she valued his opinion, especially when it came to dealing with the reinstitution of the old religion. ${ }^{301}$

Mary also felt that the situation in England was too dangerous for Pole to return and she wrote to him again on November 15, 1553 stating that Pole should delay his arrival in England and also have his "commission (as legate) suspended."302 She wrote that she only asked him to delay his trip for his own safety. Mary said that she wished to see him and "show my goodwill," in regards to the aid he provided as papal legate, and that she soon hoped to see "the realm peaceful and free of heresy." ${ }^{303}$ While her first parliament was able to repeal many of Edward's laws and edicts, it would take more time to fully restore obedience to the Church and the pope. ${ }^{304}$ Pole was happy that Mary was able to accomplish legitimizing her parents' marriage and repealing the laws from previous regimes, but he felt that "obedience should have come first.",305

Over the next few months, Pole and Mary corresponded about the status of religion in England. Mary delayed fully committing to Rome publicly and welcoming

\footnotetext{
299 Ibid., 222-223.

${ }^{300}$ Ibid., 223.

${ }^{301}$ Ibid.

302 Ibid, 228.

303 Ibid.

304 Ibid.

${ }^{305}$ Ibid., 236.
} 
Pole to England because she feared rebellions. Mary knew that her best course of action with welcoming back papal authority lay in her moving slowly and cautiously. Within the first year of her reign, Mary faced and put down threats of rebellion, such as the Wyatt Rebellion. ${ }^{306}$

Obedience to Rome was not the only thing on Mary's mind. Mary needed to marry so she could provide an heir to the throne. Mary favored a match with Philip II of Spain. Her councilors and Pole were not happy with this decision because they had their own opinions about whom she should marry. ${ }^{307}$ Mary's councilors feared that a foreign husband would replace the current English advisors with his own foreign advisors. ${ }^{308}$ However, there were no eligible English men Mary wanted to marry, so she had to look outside of England for a suitable match. ${ }^{309}$ Philip and his retinue arrived in England in July 1554 for his marriage to Mary that took place shortly after his arrival.

Once Philip came into the picture, Pole had to deal with Mary and her new husband. Mary was aware that as a woman she was expected to defer to the wills of the men surrounding her, especially her husband. Mary's status as a female monarch did not help her gain any allies. Even those who supported her, like Pole, had their doubts about her ability to rule that were completely based in her gender. She had to prove herself capable of ruling England and in the process, she blazed the trail for other female monarchs who followed her, including her sister, Elizabeth I. ${ }^{310}$ In order to prevent Philip from taking over, Parliament put in several clauses in the marriage treaty that

\footnotetext{
${ }^{306}$ Richards, Mary Tudor, 149-153.

${ }^{307}$ Ibid., 143.

${ }^{308}$ Ibid., 144.

${ }^{309}$ Ibid.

${ }^{310}$ Ibid., 2.
} 
prevented Philip from taking over England. ${ }^{311}$ One of the clauses was that he was king in name only and would act as Mary's consort. But most importantly, if Mary died without a child then England would not belong to Philip, but would revert back to the English line of succession. $^{312}$

However, Charles V and Philip both had their own plans for Mary and England and did their best to try and keep Pole from arriving in England and influencing Mary. David Pill, author of The English Reformation 1529-58, states that Mary and Pole shared a "religious zeal" that brought them close together and Pole became Mary's confidant during the majority of her reign. ${ }^{313}$ Pole continued to urge Mary to publicly show her obedience to the Catholic Church, but she remained reluctant until after she and Philip married in July 1554. Pole also hoped that after the wedding he would be allowed back into England because he felt that any more delays to his arrival would only cause more problems for his work as legate. ${ }^{314}$

Even after Philip and Mary married, it was still difficult for Pole to be let back into the country. Pole was still listed as a traitor after he wrote against Henry's split from Rome. Parliament had to repeal the act that made Pole a traitor and an outlaw before officially welcoming him back to his home country. ${ }^{315}$ In September 1554, Pole wrote to Philip and all but demanded that he be admitted into England. Pole claimed that he had been waiting for over a year and that he "came in the name of the 'successor to Peter', or

\footnotetext{
${ }^{311}$ Ibid., 148.

312 Ibid.

313 Pill, The English Reformation 1529-58, 182.

${ }^{314}$ Mayer, The Correspondence of Reginald Pole, A Calendar, 1547-1554: A Power in Rome, vol. 2 of The Correspondence of Reginald Pole., 332.

${ }^{315}$ Pill, The English Reformation 1529-58, 182.
} 
'Peter himself.",316 Pole again wrote about how Mary's accession to the throne was the work of "divine providence" and that Philip should respect the will of God, meaning that Philip should not try and take her power for himself. ${ }^{317}$ Pole continued, "think about divine providence and your new title of Defender of the faith, given by Peter's authority, and yet you leave his legate unadmitted, offending Christ and his legate who ought to have been heard first." 318

Pole took a different tone with Philip than he did in his letters to Mary. When Pole wrote to Mary the tone was careful but authoritative. He wrote to her as a teacher would write to a pupil, with the expectation of being obeyed. When Mary did not obey him, Pole was more forceful in his letters but still maintained a tone of respect for the queen. Even his letters to Mary that showed displeasure in her actions, or lack thereof, were restrained and he never fully unleashed his irritation on the queen. He knew she was fragile, especially after all the hardships she endured in her life. He acknowledged this on several occasions in his correspondence, not only with Mary but also with Pope Julius III. $^{319}$

With Philip, Pole was more challenging in his correspondence. He was more blunt and did not hide his displeasure at not being let back into England. Pole was not afraid to anger Philip by showing his frustration. In late September 1554, Pole wrote "danger if you hold Christ off, and do not immediately admit the legate demanding obedience. Should be 'as the foundation stone of the whole building'. If you try to use

\footnotetext{
${ }^{316}$ Mayer, The Correspondence of Reginald Pole, A Calendar, 1547-1554: A Power in Rome, vol. 2 of The Correspondence of Reginald Pole, 338.

${ }^{317}$ Ibid.

${ }^{318}$ Ibid.

${ }^{319}$ Ibid., 137.
} 
any other, I denounce and predict with Christ the destruction of the house. ${ }^{320}$ Pole also wrote that "you or your councilors perhaps are afraid, not the queen. If you want to avert divine anger, admit me "with the mandates of peace.",321 Pole also appealed to Emperor Charles V to allow him into England. While Pole was still in Brussels he wrote to Charles, "frequently turned to you in the past. More so now that divine providence has given government to your son. Other embassies let in, but papal legate kept waiting for more than a year. Let me in! Cannot delay.",322

Pole was determined to get back into England and bring its people back under the authority of the Roman Catholic Church. Ever since the split from Rome and the creation of the independent Anglican Church, the people of England existed under an interdict, "a papal sentence which cut the people off from the sacraments of the Church." ${ }^{323}$ Pope Julius III gave Pole the power to lift that interdict and restore England to the path to salvation. Pole felt the weight of this responsibility and was determined to enforce his powers and return his country to the authority of the Roman Catholic Church to spare the people's souls from eternal damnation. ${ }^{324}$

Even though Pole could not come to her and help her in person, Mary still asked for his advice. For example, she wrote to him asking for his approval of twelve bishops in March 1554. ${ }^{325}$ And in May 1554, Mary wrote to Pole asking him "to induce pope to allow the 'possessioners' to keep ecclesiastical property in order to facilitate her

\footnotetext{
${ }^{320}$ Ibid., 338.

321 Ibid.

322 Ibid., 340.

323 Pill, The English Reformation 1529-58, 182.

324 Ibid.

${ }^{325}$ Mayer, The Correspondence of Reginald Pole, A Calendar, 1547-1554: A Power in Rome, vol. 2 of The Correspondence of Reginald Pole, 274.
} 
marriage. ${ }^{326}$ In order for Mary to gain support from Parliament for her marriage to Philip, she and Philip had to make many concessions. Mary had to try and get the pope to allow the aristocrats who received property from the destruction of the Catholic institutions, to keep them or at least keep the money from them. Mary respected Pole's papal authority as legate and she made sure to ask his permission regarding any religious task.

Before Pole returned to England he received word that Mary was pregnant. He wrote about building the foundation of her kingdom from obedience to the Church and added an affectionate aside when he wrote "glad to hear of your pregnancy. Hope you get grace to be mother to heirs of eternal kingdom. Have been pregnant in spirit with them for long time." 327 This pregnancy would prove to be what is now known as an hysterical pregnancy. It was the first of two instances where Mary thought she was with child. $^{328}$

Once Pole arrived back in England in November 1554, he and Mary continued their work to restore the Catholic Church in England. It is during this time that one can see that Mary and Pole became close friends and religious allies. Pole wrote to Innocenzo Del Monte, another cardinal, about his arrival in England. In this letter Pole described his journey as well as the affection and respect he received when he finally met with Mary and Philip. He described his meeting with Mary, "told Mary of God's great favor to her in having the two greatest powers in the world help her. Both very glad to

\footnotetext{
${ }^{326}$ Ibid., 294.

327 Ibid., 354.

${ }^{328}$ Richards, Mary Tudor, 173.
} 
see me."329 Mary was happy to see Pole return to England. In fact, according to some sources, when Mary and Pole greeted one another, Mary felt her supposed child move within her stomach. ${ }^{330}$ A month later Julius III wrote to Pole, Mary, and Philip about the reconciliation between England and the papacy, that officially took place on November 30, 1554. ${ }^{331}$ England and Rome were finally reunited and Pole could perform his duties as he intended to do. He and Mary began to work more closely together to continue the restoration of the Roman Catholic Church in England.

Beginning in 1555, Pole began to exercise his legatine powers in England, forcing clergy to swear oaths to the papacy, abandon their marriages if they wished to remain members of the clergy, and most importantly, ensuring that the correct orthodoxy was being practiced within every diocese in England. ${ }^{332}$ When Pole finally reached England, he became the most influential religious man in the country. He revealed his plans to return England to true Catholicism to those bishops and clergymen who agreed to accept papal authority. Mary asked Pole to be her new Archbishop of Canterbury shortly after his return to England. Pole was officially consecrated Archbishop of Canterbury on March 22, 1556, in London instead of Canterbury due to the political unrest throughout England. ${ }^{333}$ Unlike Cranmer, Pole needed the approval of the pope in order to become

\footnotetext{
${ }^{329}$ Mayer, The Correspondence of Reginald Pole, A Calendar, 1547-1554: A Power in Rome, vol. 2 of The Correspondence of Reginald Pole, 264.

${ }^{330}$ Richards writes in her book that Mary was skeptical about her supposed pregnancy even though her doctors had confirmed it. Richards writes, "Mary's skepticism was apparently overcome some two weeks after Mason reported his conversation about it, for when, in late November, Mary met Pole again after two decades, she reported that she then felt a quickening in her womb. She had finally accepted that what her doctors had been diagnosing as a pregnancy was indeed just that." Richards, Mary Tudor, 174.

331 Mayer, The Correspondence of Reginald Pole, A Calendar, 1547-1554: A Power in Rome, vol. 2 of The Correspondence of Reginald Pole, 268.

${ }^{332}$ Edwards, Archbishop Pole, 141.

${ }^{333}$ Ibid., 168.
} 
archbishop. Once the pallium, an ecclesiastical vestment granted to the archbishop by the pope, arrived in London, Pole was officially archbishop. ${ }^{334}$

During late 1554 and early 1555, Mary was still under the impression that she was pregnant. However, when Mary's pregnancy proved to be false, Philip left England to attend to his empire. Mary was saddened by the departure of her husband. Some accounts claim she was despondent with grief while others say that court seemed to carry on as it had just the same as if Philip were present. ${ }^{335}$ Mary trusted Philip and relied on him for many things. She took his advice and followed his lead as a ruler and often took his side when it came to making decisions. Pole wrote to Mary shortly after Philip's departure and offered her some consolation in the form of a prayer that would help her feel better. ${ }^{336}$

While Mary may not have been as despondent as some sources state, she was nonetheless grieved by Philip's absence. By all accounts, Mary was a loyal and dutiful wife. She submitted to Philip in many things, as a wife was expected to do. She issued an order to her council that all state papers were to be signed by both Philip and Mary, and Philip's name always came before Mary’s. ${ }^{337}$ While Mary and her councilors ensured that Philip had no direct control over matters in England, Pole's letters state that Philip exercised some control over Mary while he was abroad and left specific

\footnotetext{
334 Ibid., 169.

335 Richards recounts the Venetian ambassador's account of Philip's departure from England. "Mary, again according to the Venetian ambassador, controlled her grief so regally and so well that no one could have guessed its extent. Once she was alone however, he reported, she collapsed into deep sobbing, gazing after Philip's ship long after it was out of sight." Richards states that this is the traditional image of Mary when her husband left but she also states that the ambassador who reported it claimed that there were no witnesses, so the claim is not supported by any solid evidence. Richards, Mary Tudor, 180-81.

${ }^{336}$ Thomas F. Mayer, The Correspondence of Reginald Pole, A Calendar, 1555-1558: Restoring the English Church, vol. 3 of The Correspondence of Reginald Pole (Aldershot, England: Ashgate Publishing Limited, 2004), 157.

${ }^{337}$ Richards, Mary Tudor, 163-164.
} 
instructions for her, Pole, and Parliament about what to do in his absence. ${ }^{338}$ Pole wrote to Philip on September 16, 1555, shortly after Philip left England, and said that "no one could execute your orders better than she." ${ }^{339}$ While accounts differ about how much influence Philip had over Mary and how she ruled England, many sources describe her as a virtuous woman who played the role of wife as any devout woman would.

Pole wrote to Philip regularly during the king's absence from England. In these letters, he assured Philip that Mary was following his orders in regards to ruling the kingdom and that Pole was also following his instructions, such as to keep Mary busy in government. ${ }^{340}$ Pole also wrote, "the first duty you assigned me was to console queen during your absence." ${ }^{341}$ Pole consoled and comforted Mary during Philip’s absence and when he wrote to Philip he urged him to return speedily for the good of Mary. Philip's departure only added to Mary's distress after discovering she was not pregnant. But Philip had his own empire to see to. Charles V was still alive but he was ill and unable to oversee all of his empire. Charles needed Philip to come to him and formally accept his role as king of Spain. ${ }^{342}$ Philip left England for Brussels in August 1555 and Charles officially abdicated in 1556. Philip now assumed the role of King of Spain, and oversaw territory in the Netherlands, Italy, and the New World. ${ }^{343}$ While Philip was absent, Pole kept Mary busy with the running of her country and the Church in England. Pole was

\footnotetext{
${ }^{338}$ Ibid., 184.

${ }^{339}$ Mayer, The Correspondence of Reginald Pole, A Calendar, 1555-1558: Restoring the English Church, vol. 3 of The Correspondence of Reginald Pole, 166.

${ }^{340}$ Ibid., 160.

341 Ibid.

${ }^{342}$ Richards, Mary Tudor, 180.

${ }^{343}$ Guy, Tudor England, 239.
} 
worried about Mary and he usually included a comment to Philip about how his return would benefit the queen. ${ }^{344}$

Pole's continued requests for Philip to return to England on Mary's behalf shows his affection for the queen. He saw her distress and knew she would be comforted by her husband's return. In Philip's absence, Pole and Mary worked closely together to turn England back to the papacy and restore the Catholic Church in England. Pole opened a synod to determine how much work needed to be done to restore England to Catholicism. This synod took place between 1555 and 1556 and discussed a range of topics including education, preaching, the role of bishops, and possible sermons. ${ }^{345}$ Pole sent men out to every parish and diocese to see what needed to be done and then the synod committee would meet again to plan their next move. Meanwhile, Mary began her famous campaign against heretics against her religion.

Mary's reign remains forever marred by the hundreds of men and women she burned at the stake for heresy. In less than four years, close to three hundred Protestants burned at the stake for their heresy. ${ }^{346}$ Heresy was a criminal offense and punishable by death. Mary and her government identified heresy with treason also because many Protestants supported Mary's sister, Elizabeth, and her claim to the throne. Mary was determined to root out all threats against her reign, but most importantly she wanted to get rid of heresy in England. Mary kept herself busy with this while Philip was absent

\footnotetext{
${ }^{344}$ Mayer, The Correspondence of Reginald Pole, A Calendar, 1555-1558: Restoring the English Church, vol. 3 of The Correspondence of Reginald Pole, 166.

${ }^{345}$ Edwards, Archbishop Pole, 171-179.

${ }^{346}$ Eamon Duffy writes in his book, Fires of Faith: Catholic England under Mary Tudor, that more than 280 Protestant, both men and women, were burned between February 1555 and November 1558. Accounts differ as to the exact number of executions Mary ordered during her reign but most sources agree that the number lies around three hundred. Eamon Duffy, Fires of Faith: Catholic England under Mary Tudor (New Haven: Yale University Press, 2009), 7.
} 
from England. She and Pole worked together to determine what needed to be done to restore Catholicism in England. ${ }^{347}$

Pole continued to write to Philip and beseeched him to return to England and “console the queen."348 With Philip gone as often and for as long as he was, Pole remained at Mary's side to provide support and guidance. Philip and Mary's relationship changed after her first hysterical pregnancy during 1554-1555 and Philip did not stay in England unless it was necessary. Philip wrote to Pole in the fall of 1556, presumably while he was still away from England or at least away from Mary, and told Pole that he "will come as soon as possible, not approving your trip to Canterbury to meet me, in order not to take you away from Mary." ${ }^{, 349}$ Philip knew how important it was for Mary to have Pole nearby, especially in Philip's absence.

Mary's last couple of years on the throne were particularly stressful. Her husband was often away from England and pressured her to contribute men and money to his war on the continent. ${ }^{350}$ She faced animosity regarding her determination to return England to the fold of Rome and her Spanish leanings. And on top of all that, she feared rebellion from her Protestant subjects. Mary was paranoid about Protestants infiltrating her castles and assassinating her and only allowed a few people around her. ${ }^{351}$ She was increasingly afraid that another rebellion would rise up and replace her with Elizabeth. This paranoia

\footnotetext{
${ }^{347}$ Eamon Duffy writes more about the changes and restructuring of the church within England in his book, Fires of Faith: Catholic England under Mary Tudor. He goes into more detail about the executions, the role of Cardinal Pole, and how the religious reformation went from persuasion to outright violence. Eamon Duffy, Fires of Faith: Catholic England under Mary Tudor (New Haven: Yale University Press, 2009).

${ }^{348}$ Mayer, The Correspondence of Reginald Pole, A Calendar, 1555-1558: Restoring the English Church, vol. 3 of The Correspondence of Reginald Pole, 221.

349 Ibid., 295.

${ }^{350}$ Richards, Mary Tudor, 212-213.

${ }^{351}$ David Loades, Mary Tudor: A Life (Oxford: Oxford University Press, 1990), 265.
} 
may have contributed to Mary's dedication to carrying out the persecutions against Protestants in England.

Pole knew what she faced and stuck with her until the end. He remained in England to guide Mary and support her through the turbulence of her reign. He supported her through her second hysterical pregnancy and the frequent absences of her husband. Pole did these things for Mary's well-being. Their shared enthusiasm and dedication to the Catholic Church bonded them together. They both felt a divine calling to set England back on the path to salvation. He cared for her on a personal level and tried to do all in his power to help her and make her happy. There is not much correspondence between Pole and Mary once Pole arrived in England but they often worked closely together, especially on the religious policies. ${ }^{352}$

On the morning of November 17, 1558, Queen Mary I died. Pole, on his deathbed at Lambeth, wept when he heard the news. He felt that he and Mary had so much in common, especially when it came to experiencing hardships for their faith. ${ }^{353}$ Duffy writes "in that collaboration [the restoration of Catholicism to England] the bond of their shared Plantagenet blood had been intensified by a 'great conformity of mind and spirit." $" 354$ Only a few hours later, Pole passed away, leaving the Marian Restoration unfinished. Given how close Mary and Pole became during the last years of their lives, it seems only fitting that they died on the same day.

The relationship between Mary and Pole was the reason why the church in England restored its papal connection and many of the other Catholic traditions that were abolished by Edward and Henry. Their cooperation and determination to complete

\footnotetext{
${ }^{352}$ Duffy, Fires of Faith: Catholic England under Mary Tudor, 114.

353 Ibid., 188.

${ }^{354}$ Ibid.
} 
Catholic restoration in England not only brought them closer together but also kept them focused on their goal. Through Mary and Pole's work, England had a strong foundation to reestablish the church as it was in England during the early years of Henry's reign. Unfortunately for them and their work, Elizabeth and her government quickly did away with any Catholic restoration once she took to the throne. 


\section{CHAPTER 5}

\section{MATTHEW PARKER AND ELIZABETH I: NAVIGATING THE MIDDLE PATH}

After Mary's death, the next heir to the throne was her younger half-sister

Elizabeth, the only child of Henry VIII and Anne Boleyn. Elizabeth, like her sister Mary, was cast aside when her mother fell from her father's favor. After Anne Boleyn was beheaded in 1536 , her daughter was left to the mercy of her father and many were unsure of what would happen to the princess. Following her mother's execution, she lived away from court under the supervision of attendants and tutors. ${ }^{355}$

As an adult, Elizabeth rebelled against her sister's Catholic religion. She was not, however, fully committed to Protestantism either. ${ }^{356}$ Her faith closely followed that of her father, Henry VIII. In other words, she did not want to recognize the pope as her spiritual leader but she still maintained some Catholic traditions, such as keeping a crucifix in her chapel and discouraging clerical marriage. It surprises some that Elizabeth chose a married Protestant as her new Archbishop of Canterbury. Matthew Parker was a supporter of the Protestant reforms in England and wanted to continue the work of Cranmer and Edward regarding the church in England. Parker was also honor bound to serve Elizabeth because of a promise he made to her mother many years earlier. ${ }^{357} \mathrm{He}$ and Elizabeth worked well together, even though he grew to regret his agreement to take

\footnotetext{
${ }^{355}$ David Starkey, Elizabeth: The Struggle for the Throne (New York: Harper Collins Publishers, 2001), 23-29.

${ }^{356}$ John Guy, Tudor England (Oxford: Oxford University Press, 1988), 252.

${ }^{357}$ V.J.K. Brook, A Life of Archbishop Parker (Oxford: Clarendon Press, 1962), 16.
} 
control of the See at Canterbury. ${ }^{358}$ Elizabeth relied more on her political advisors than she did Parker, but she trusted him to oversee and enforce the religious policies that she and Parliament passed, such as the Act of Uniformity (1559). Parker tried to advise her many times throughout his sixteen years of service but she usually deferred to her political advisors or did what she wanted to do.

Their relationship shaped the church of England as it removed the Catholic influence yet again. With Mary gone, Elizabeth and Parker began to rebuild the church and slowly separate England from the papacy again. Elizabeth embraced some of the reforms from her brother's reign, such as the release of a new Book of Common Prayer and the Acts of Uniformity. ${ }^{359}$ But she also wanted to keep her crucifix in her chapel, which went against the Protestant ideal that churches should have no decorations. ${ }^{360}$ Parker followed Elizabeth's orders and enforced her Act of Uniformity and other policies but he was unsuccessful in convincing her to marry. The Church in England during Elizabeth's reign was how Elizabeth wanted it to be: a mixture of Catholic and Protestant. She and her council dictated to her archbishops, especially Parker, how they wanted the church to function. Elizabeth wanted the church in England to be Anglican, an institution that managed to navigate the middle ground between Catholic and Protestant, and she needed Parker to help her bring it to life. ${ }^{361}$

Following the death of her sister, Elizabeth arrived in London to claim the throne. Elizabeth I's accession to the throne was met by popular support in England after the

\footnotetext{
${ }^{358}$ John Bruce Esq., and Rev. Thomas Thomason Perowne, M.A. Eds. The Correspondence of Matthew Parker D.D., Archbishop of Canterbury (Cambridge: Cambridge University Press, 1853), 391.

${ }^{359}$ Guy, Tudor England, 262.

${ }^{360}$ Ibid., 252.

${ }^{361}$ Christopher Hibbert, The Virgin Queen: Elizabeth I, Genius of the Golden Age (Reading, MA: AddisonWesley Publishing Company, Inc., 1991), 95.
} 
years of unpopular policies and persecutions committed by Mary and her government. ${ }^{362}$ Many people also hoped that with the coronation of Elizabeth, England and her people would see the end of foreign influences, particularly from Spain and Rome. When Elizabeth came to the throne, she knew that she could not perpetuate the religion and policies of her sister. Norman Jones states in his article "Elizabeth's First Year: The Conception and Birth of the Elizabethan Political World," that because of events in her life, Elizabeth had to "return to the Protestant status quo."363 As the "living symbol" of Henry VIII's break with Rome, Elizabeth was never recognized as his legitimate heir in Rome, even though she was accepted by Henry and Englishmen. What is more, she also believed that she should be in charge of the Church in England, something she knew no pope would ever agree nor consent to. ${ }^{364}$

Elizabeth set out to change the way that England functioned during Mary's reign. She altered the religion again and also decided to rule without a husband. Though Elizabeth is often remembered as the Virgin Queen, her decision to reinstate some of her brother's Protestant policies and separate the Anglican Church from the papacy again was also monumental. This decision was widely popular because many people in England, including the nobility, did not want any more foreign influence. Elizabeth was the "Protestants' hope" after Mary's Catholic reign, even though she did not consider herself a Protestant. ${ }^{365}$ One of the first tasks Elizabeth had to complete for the church in England

\footnotetext{
362 Ibid., 250.

${ }^{363}$ Norman L. Jones, “Elizabeth's First Year: The Conception and Birth of the Elizabethan Political World," in The Reign of Elizabeth I, ed. Christopher Haigh (Athens: The University of Georgia Press, 1985), 28. 364 Ibid.

${ }^{365}$ Guy, Tudor England, 251.
} 
was to appoint a new Archbishop of Canterbury. Her choice, Matthew Parker, was reluctant to take on this important role, but in the end he accepted.

Parker had a reputation as a reformed thinker from the beginning of his involvement with Henry VIII's court. Born in 1504, Parker entered Cambridge in his late teens and became a priest in $1527 .{ }^{366}$ Parker was part of the group of prominent English scholars who participated in discussions about Martin Luther and his ninety-five theses during his years at Cambridge. ${ }^{367}$ Parker's reputation among his peers as a reformer earned him some attention and he was summoned to the royal court.

When Parker began his preaching career in the 1530s, he preached sermons before King Henry and his court, including Elizabeth and Edward. ${ }^{368}$ In 1535, he was called to become one of Queen Anne Boleyn's chaplains. While working for Queen Anne, he was able to curry favor with the queen. She thought so highly of him that he was named the Dean of Stoke-by-Clare, one of England's prominent colleges for priests, with her endorsement. ${ }^{369}$ Shortly before Anne Boleyn was arrested, she committed the spiritual welfare of her daughter, Elizabeth, to Parker. ${ }^{370}$ This promise Parker made to the late Anne Boleyn influenced his agreement to take control of the See at Canterbury. Parker's association with Anne Boleyn did not hinder his reputation in any negative ways after she was arrested and executed by Henry in May $1536 .^{371}$ In 1538 , Henry appointed Parker as one of his chaplains and ensured he received his own stipend,

\footnotetext{
${ }^{366}$ Brook, A Life of Archbishop Parker, 4.

${ }^{367}$ Peter Ackroyd, Tudors: The History of of England from Henry VIII to Elizabeth I (New York: Thomas Dunne Books, 2012), 27.

${ }^{368}$ Bruce and Thomason Perowne, eds., The Correspondence of Matthew Parker D.D., Archbishop of Canterbury, ix.

${ }^{369}$ Brook, A Life of Archbishop Parker, 16.

370 Ibid.

${ }^{371}$ Guy, Tudor England, 141-142.
} 
among other honors. ${ }^{372}$ During the reign of Edward VI, Parker married and became one of the many clergymen in England to abandon clerical celibacy. While under Edward, Parker still preached and worked at Cambridge as Vice-Chancellor. He also became involved in Edward's government as a commissioner "to enquire into heresy and to punish those who opposed the Book of Common Prayer.",373

When Edward died and Mary came to power, Parker's life changed. During Mary's reign, Parker spent most of his time lying low and trying not to attract attention. As a married clergyman, he lost his preferments and positions when Mary came to power because he embraced the reformed faith rather than her Catholicism. ${ }^{374}$ Parker spent most of Mary's reign under the protection of friends, in order to avoid being arrested for treason or heresy. ${ }^{375}$ However, when Mary died and Elizabeth came to the throne, Parker was liberated from his hiding place and, within Elizabeth's first year as queen, became Archbishop of Canterbury. During his time as archbishop, he worked alongside Elizabeth and her council to remove Catholic influence in England. He kept in regular contact with Elizabeth, her chief advisor William Cecil, and her council about the running of the country and the ways in which Elizabeth should proceed in terms of religion. He served as one of her advisors, spiritual and otherwise, and did his best to keep his promise to her mother during his time as archbishop.

Elizabeth and Parker operated similarly to how Henry and Cranmer worked together. Parker did Elizabeth's bidding where the church was concerned, much as Cranmer did for Henry. They worked well together but Parker, like Cranmer, rarely took

${ }^{372}$ Brook, A Life of Archbishop Parker, 16.

${ }^{373}$ Ibid., 48.

${ }^{374}$ Ibid., 51 .

${ }^{375}$ Ibid. 
liberties with his monarch. Both Parker and Cranmer deferred to their monarch for the final decision regarding the church, because they respected that the monarch was the head of the Church in England. Elizabeth also dictated what she wanted Parker to do much as her father did to Cranmer.

When Elizabeth arrived in London after her sister's death, she began the work that would differentiate herself from Mary. She and Mary had a difficult relationship to say the least and were destined to be different monarchs. During the majority of Mary's reign, Elizabeth lived away from court where she could not cause any trouble. She was Mary's rival and there was a Protestant presence in England after Edward's reign that wanted to see Elizabeth on the throne. Whenever there was a plot to overthrow Mary, such as the Wyatt Rebellion in 1554, Elizabeth was the alternative to Mary. ${ }^{376}$ She was the next legitimate heir according to their father's will and because she portrayed herself as a good Protestant princess during Edward's reign, she was seen as such. ${ }^{377}$ Elizabeth looked to the reformed ideas of Protestantism because her legitimacy had been denied by the Catholic Church since she was born.

Mary, like her mother, remained a Catholic until her death and she tried many times to convince Elizabeth to convert. However, Elizabeth preferred to practice the religion of her father that managed to navigate the middle ground between Catholicism and Protestantism. Elizabeth was similar to her mother in many ways, from her reformist beliefs about religion to her accomplishments with languages and instruments. ${ }^{378}$ When

\footnotetext{
${ }^{376}$ Judith Richards, Mary Tudor, (London: Routledge, 2008), 149.

377 Ibid., 154.

${ }^{378}$ Guy, Tudor England, 251.
} 
Elizabeth became queen she did not want to alienate England by choosing Catholic or Protestant, so she chose a course between the two and created Anglicanism. ${ }^{379}$

When Elizabeth came to power, she did away with her sister's policies, especially the religious acts. Since religion was such an influential part of English culture and influenced much of what happened within the government, Elizabeth and her government had to remove many of Mary's Catholic policies and those policies that made Protestantism illegal in England. Elizabeth trod carefully with regard to implementing the changes she desired to make. Elizabeth's religious beliefs were conservative and she stayed in between Catholicism and Protestantism in terms of religious practices.

For example, she openly disapproved of Parker's marriage and made her feelings known on the subject to Cecil and Parker. Cecil wrote to Parker about the queen's negative feelings toward clerical marriage, "her Majesty continueth very evil affected to the state of matrimony in the clergy." 380 Parker replied "I was in an horror to hear such words to come from her mild nature and christianly learned conscience, as she spake concerning God's holy ordinance and institution of matrimony." ${ }^{381}$ Both men were surprised to know Elizabeth's feelings about clerical marriage as they both expected her to eventually marry.

As mentioned previously, the first few months of Elizabeth's reign were dedicated to altering the religious state in England, as well as changing the government and its officials to suit the new queen's needs and desires. Her greatest wish was to bring stability to England in both politics and religion. The policies implemented during the

\footnotetext{
${ }^{379}$ Starkey, Elizabeth, 92.

${ }^{380}$ Bruce and Thomason Perowne, eds., The Correspondence of Matthew Parker D.D., Archbishop of Canterbury, 148.

${ }^{381}$ Ibid., 156.
} 
period of time that followed Elizabeth's ascension to the throne became known as the Elizabethan Settlement because she tried to unify the Anglican Church under different acts, including the Acts of Supremacy and Uniformity, both passed in 1559. These acts were both submitted to Parliament without consent from any clergymen in England. Cecil drafted the Acts of Supremacy and Uniformity as one bill originally but they were too controversial to pass through both houses without issue. After they were separated, the bills were passed by both the House of Commons and the House of Lords. ${ }^{382}$

The new supremacy act replaced Henry VIII's act passed in 1534 and named the monarch of England as the "Supreme Governor of the Church" as opposed to the "Supreme Head of the Church." ${ }^{\text {"3 }}$ The new title of governor for the monarch appeased some of the more conservative members of Parliament who believed that only Jesus should be referred to as the head of the church. ${ }^{384}$ Elizabeth still maintained jurisdiction over the church in England but the title itself was altered in order to get the law to pass through Parliament. The new supremacy act also "authorized communion in both kinds; repealed the heresy laws; and reinstated the Henrician act for consecrating bishops.. ${ }^{385}$ After the break with Rome, in order for a new bishop or archbishop to be consecrated one archbishop and two bishops or four bishops had to preside over and perform the ceremony. ${ }^{386}$ In addition to the new supremacy act, Elizabeth and her government also passed the Uniformity Act, which reintroduced the Prayer Book of 1552 with some alterations. ${ }^{387}$ These bills included ideas that would appeal to both Protestants and

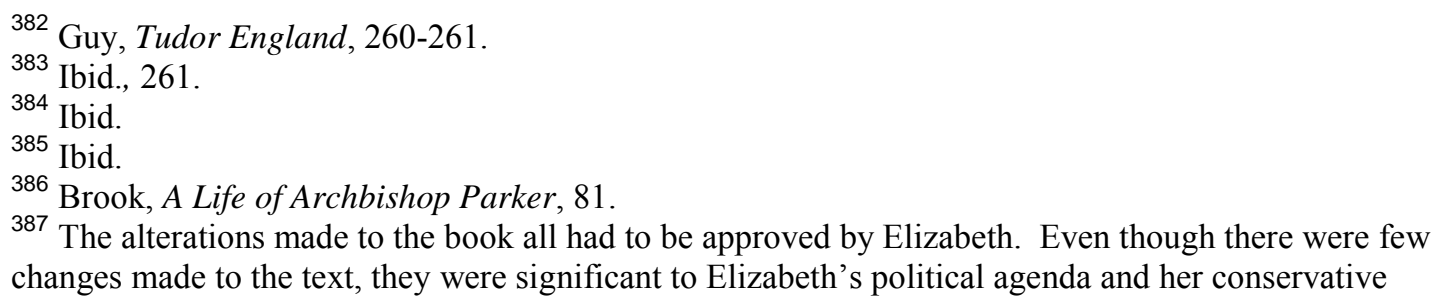
changes made to the text, they were significant to Elizabeth's political agenda and her conservative 
Catholics, such as changing the monarch's title to please both the Protestants and Catholics. Implementing the Prayer Book would further placate the radical Protestants. Elizabeth, ever the pragmatist, wanted these bills to appease the most people in England regarding religious practices. ${ }^{388}$

Following the passage of the Supremacy Act and the Uniformity Act, Elizabeth and Cecil began to reinstate some of the bishops who had been deposed by Mary in order to consecrate Parker as her new archbishop. The consecration required four bishops and at this time, they did not have four bishops who would agree to perform the ceremony. ${ }^{389}$ Parker was reluctant to take this position and he wrote of his reservations to Sir Nichols Bacon, Elizabeth's Lord Keeper of the Great Seal. Parker wrote that he was not qualified enough to accept this position. He mentioned his many infirmities that resulted from his old age and that "though my heart would right fain serve my sovereign lady the Queen's majesty. . . Yet this my painful infirmity will not suffer it in all manner servings." ${ }^{390}$ Parker was in his mid-fifties, considered an elderly man by many at this time, when Elizabeth asked him to be her archbishop.

Parker also wrote to Elizabeth about his "unworthiness for so high a function.",391 Parker claimed that the office was too high above him and his position and it "doth require a man of much more learning, virtue, and experience, than I see and perfectly

preferences. There were no longer any negative references to the Pope in the new Book and the wording regarding Eucharist was much more liberal. The Knoxian 'Black Rubric,' which "explained away the practice of kneeling at the reception of communion" was omitted. And an Ornaments Rubric was "inserted before Morning and Evening Prayer." A.G. Dickens, The English Reformation (New York: Schocken Books, 1964), 303-304.

${ }^{388}$ Guy, Tudor England, 260-262.

${ }^{389}$ Brook, A Life of Archbishop Parker, 81.

${ }^{390}$ Bruce and Thomason Perowne, eds., The Correspondence of Matthew Parker D.D., Archbishop of Canterbury, 59.

${ }^{391}$ Ibid., 70. 
know can be performed of me." ${ }^{392}$ In this letter, Parker also referred to the promise he made to Elizabeth's mother shortly before her arrest. He wrote, "and where, most gracious lady, beside my humble duty of allegiance to your princely dignity, I am otherwise, for the great benefits which sometime I received at your grace's honourable mother's benevolence (whose soul I doubt not but is in blessed felicity with God) most singularly obliged, above many other, to be your most faithful bedesmen. . ."393 Ultimately, Parker agreed to be her new Archbishop, despite his self-proclaimed shortcomings. This letter Parker wrote to Elizabeth shows his loyalty to her and his gratitude toward her mother. He deferred to Elizabeth's desire because he did not want to deny her his presence in the office of archbishop and he felt that it was part of his duty in keeping his promise to her mother. He would most likely have preferred to retire instead of take on the most powerful See in England. In a later letter, dated May 19, 1572, Parker wrote that if he "had not been so bound to the mother, I would not so soon have granted to serve the daughter in this place."394

Parker was consecrated on December 17, 1559. His consecration was confirmed by four bishops instead of by papal authority, as prescribed by the Act of Supremacy that Elizabeth reinstated. ${ }^{395}$ Now that Parker was in office he and Elizabeth appointed more bishops, including Parker's successor, Edmund Grindal as Bishop of London. Parker and his newly consecrated clergymen then set out to organize the Anglican Church under the new specifications of the Acts of Supremacy and Uniformity and the Injunctions of 1559. Some of these injunctions included reciting the liturgy in English, having an English

\footnotetext{
392 Ibid., 70.

393 Ibid.

${ }^{394}$ Ibid., 391.

${ }^{395}$ Brook, A Life of Archbishop Parker, 80.
} 
Bible in every church, and removing religious imagery and monuments from churches, among many other alterations. ${ }^{396}$ Parker and the other bishops were charged with ascertaining how well the people of England were adapting and implementing these new changes in their own respective dioceses. They would accomplish this by visiting the churches in their diocese and ensuring that they all met the new Act of Uniformity.

Parker maintained a steady correspondence with Elizabeth and members of her council, including William Cecil and Nicholas Bacon, during his tenure as archbishop. They discussed a multitude of things from religious policies to the potential marriage of the queen. Parker wrote numerous letters to Elizabeth that were full of requests for the Church in England. ${ }^{397}$ In a letter dated in 1559, Parker and unnamed others wrote to Elizabeth requesting that they be allowed to refuse placement of and remove all idols and images of Christ in the churches. ${ }^{398}$ They provided evidence from scripture to support their request but they deferred to the judgment of the queen, who as Supreme Governor of the Church had the final word. ${ }^{399}$

Parker and his colleagues wrote, "we pray your Majesty also not to be offended with this our plainness, and liberty, which all good and Christian princes have ever taken in good part with at the hands of godly bishops.." ${ }^{400}$ Parker and the others also requested that "your Majesty also in these, and such-like controversies of religion, to refer the discussment and deciding of them to a synod of your bishops, and other godly learned

\footnotetext{
${ }^{396}$ Ackroyd, Tudors, 297.

${ }^{397}$ Bruce and Thomason Perowne, eds., The Correspondence of Matthew Parker D.D., Archbishop of Canterbury, 79-95.

${ }^{398}$ Ibid.

399 Ibid., $80-84$.

${ }^{400}$ This letter was written by “Archbishop Parker and Others" to Queen Elizabeth. The "others" are never specified throughout the letter but one can assume they are a group of bishops or clergymen that worked with Parker to enforce the Injunctions of 1559 and other religious policies passed during the Elizabethan Settlement. Ibid., 94.
} 
men."401 This suggestion by Parker and his co-authors shows that they did not want to defer to her regarding religious matters. The authors of the letter also begged Elizabeth "to consider, that besides weighty causes in policy, which we leave to the wisdom of your honorable councilors, the establishing of images by your authority shall not only utterly discredit our ministries, ... But also blemish the fame of your most godly brother," and others who gave their lives "for the testimony of God's truth, who by public law removed all images." ${ }^{, 402}$ Parker and the others were polite and reverent to the queen, but they also were not afraid to be forceful in the way they wrote to her, similar to how Pole wrote to Mary at the beginning of her reign. However, they also hoped she would let a synod of bishops make most of the religious decisions in England as opposed to Elizabeth making the decision as the Supreme Governor.

This letter from Parker and a group of others to Elizabeth represents one way that Parker attempted to keep his word to Anne Boleyn. The subject of the letter, the removal of images and idols from the churches in England, was one that Protestants took seriously. Protestant faith during this time was in many ways contradictory to the Catholic faith. Catholic churches were known for their ornate decorations, such as stained glass windows, crucifixes, and images of saints. The Protestant faith did not encourage the cult of saints nor the ornate decoration of churches. Protestants felt that these things distracted people from their devotion to their faith. Drawing on pervious teachings by Calvin and Luther, Protestants were careful not to encourage idolatry by placing images in their churches. By writing this letter, Parker and his colleagues encouraged Elizabeth to allow them to remove the images from churches and by her will

401 Ibid.
${ }^{402}$ Ibid. 
"purge the polluted church, and remove all occasions of evil." $" 403$ To Parker, this adherence to this idea would keep Elizabeth on the path to salvation and benefit her spiritual welfare, helping him keep his word to her mother.

Another matter Parker advised Elizabeth on was marriage. Elizabeth seemed disinclined to the idea of marriage for many years, even after she became queen. Unlike her sister, she never seemed to desire to marry and have children, at least not until it was expected of her as a monarch. She never spoke out against marriage, except clerical marriage, and she understood that one of her duties as queen was to provide an heir to the throne but she was still reluctant to marry. ${ }^{404}$ Elizabeth openly disapproved of Parker's marriage and refused to address Parker's wife as "mistress" when they met. ${ }^{405}$ Some authors speculate that her disinclination to marry was due to the fact that she was exposed to so many stepmothers in her childhood. ${ }^{406}$ Whatever the reason for her hesitation to marry, her councilors, including Parker, pressured her to marry. Royal marriages were expected not only to yield an heir to the throne but to also bring some kind of political and/or religious benefits, such as wealth and alliances. ${ }^{407}$ Kings and queens rarely married based on affection, they married in order to gain political and/or economic power and influence. For example, when Henry VIII married Katherine of Aragon it was to solidify an alliance between England and Spain that would prevent an alliance between France and Spain.

\footnotetext{
403 Ibid., 79.

${ }^{404}$ Ibid., 148 and 156.

${ }^{405}$ Brook, A Life of Archbishop Parker, 37.

${ }^{406}$ Norman L. Jones, "Elizabeth's First Year: The Conception and Birth of the Elizabethan Political World," in The Reign of Elizabeth I, ed. Christopher Haigh (Athens: The University of Georgia Press, 1985), 29.

${ }^{407}$ Carole Levin, "The Heart and Stomach of a King”: Elizabeth I and the Politics of Sex and Power (Philadelphia: University of Pennsylvania Press, 1994), 43.
} 
No one expected Elizabeth to remain single, especially given the male-dominated culture of England and Europe at this time. The queen was not supposed to rule on her own, without the guidance of a man. However, when a woman married she was expected to bow to the will of her husband and for a female monarch the line between queen and wife was difficult to make out. For example, during Mary's reign, England was ruled by Philip II, Mary's husband, through Mary. Elizabeth's councilors expected her to marry and for whomever she chose to marry to help her rule. However, no one, including Elizabeth, could yet conceive the idea of a "forever virgin-queen." $" 408$

In addition to having someone to help her rule, marriage would also provide Elizabeth with an heir to follow her on the throne. Her father's memory had already been tainted by his string of marriages to beget a son. Due to the male-dominated culture, many men during this time felt the same and did not trust that a woman could rule on her own, as one had not done so before. If Elizabeth remained unmarried, she would be the first anointed queen to rule England without a husband. Also, Mary's lack of popularity did not encourage much faith in a female ruler among the people. Elizabeth would prove them wrong but not before her councilors, especially Parker, tried to convince her to give in to marriage.

In the letter dated sometime in 1560, Parker and a group of bishops wrote to the queen that she should marry, and soon. Parker and Elizabeth's councilors placed pressure on the queen to marry: "marriage we all wish to see your godly affection inclined to, whereby your noble blood might be continued to reign over us to our great joy and comfort, whereby the great fears of ruin of this your ancient empire might be

\footnotetext{
${ }^{408}$ Norman L. Jones, "Elizabeth's First Year: The Conception and Birth of the Elizabethan Political World," in The Reign of Elizabeth I, ed. Christopher Haigh, 29.
} 
prevented, and the destruction of your natural-born subjects avoided." ${ }^{409}$ If Elizabeth did not have any children, the throne would go to the heir of Henry VIII's sister, Margaret Tudor, who turned out to be Mary Stuart, also known as Mary Queen of Scots. Mary Stuart was also a Catholic, which would mean another change for the English people, the potential destruction of Elizabeth's work, and maybe the return of papal authority in England. The best way to avoid these problems was for Elizabeth to marry and produce her own legitimate heir.

Parker and his fellow bishops wrote to Elizabeth about her potential marriage not as political advisors "but as Christ's ministers in vigilancy, ..."410 They wrote to the queen about this because it was part of their job as Christ's ministers to burden the queen's "conscience in charity; which is a case incident in our ministry, evermore favourably heard of princes, and faithfully observed of pastors."411 They specified, "that is to say, to regard the continuance of sincerity on doctrine, unity in common Christian charity, and safety of realms by godly succession in blood." ${ }^{, 412}$ Parker and the other bishops encouraged Elizabeth to marry in order to maintain religious continuity in England. Also, in their own self-interest, they would not want to see a Catholic succeed Elizabeth because they might lose their positions or be executed for heresy, as many Protestant bishops and clergymen were under Mary. Parker wrote to Elizabeth about this in order to encourage her to fulfill her duty as queen and safeguard the future of England. ${ }^{413}$ This encouragement from Parker also qualified as protecting the Elizabeth's

\footnotetext{
${ }^{409}$ Bruce and Thomason Perowne, eds., The Correspondence of Matthew Parker D.D., Archbishop of Canterbury, 131.

${ }^{410}$ Ibid.

${ }^{411}$ Ibid.

412 Ibid.

${ }^{413}$ Ibid.
} 
spiritual welfare because her marriage and the birth of an heir would ensure the survival of the "true religion" in England and secure not only Elizabeth's salvation but also her people's.

Elizabeth did not seem to take issue with Parker pressuring her into marriage, but that cannot be known for sure as her response has been lost. ${ }^{414}$ Her relationship with Parker seemed to remain as it was before he wrote the letter encouraging her marriage. Elizabeth already tasked Parker with enforcing the Injunctions of 1559 and electing new bishops in sees throughout England, but she also sought his help with other matters within the church. Overseeing the implementation of the Injunctions was already a lengthy and involved task, which Parker delegated to bishops within every diocese in England, but Elizabeth used Parker to carry out some less than favorable tasks. In a letter dated January 22, 1560, Elizabeth addressed Parker and some other bishops, writing that they should be overseeing the restoration and reformations within their churches, including the physical renovations as well as the doctrinal changes. ${ }^{415}$ All of those tasks were part of the Injunctions of 1559.

Elizabeth also asked other favors of Parker during his time are archbishop. In June 1561, St. Paul's Cathedral was destroyed by fire after it was struck by lightning. ${ }^{416}$ Elizabeth asked Parker to collect funds from his fellow clergymen to rebuild the church. It was a task that needed to be done for the sake of St. Paul's but Elizabeth did not want to incur anger from the clergy by asking them for money, so she asked Parker to do it. However, as one of Parker's biographers, V.J.K. Brook states, Elizabeth skillfully

\footnotetext{
${ }^{414}$ Brook, A Life of Archbishop Parker, 115.

415 Bruce and Thomason Perowne, eds., The Correspondence of Matthew Parker D.D., Archbishop of Canterbury, 132-3.

${ }^{416}$ Brook, A Life of Archbishop Parker, 115.
} 
requested Parker's aid in repairing the church. ${ }^{417}$ She wrote, "to join our authority with your devotion and good will, we do authorize you by way of any manner of usual or other good conference with the bishops of your province, and the principal members of the clergy thereof, to devise some upon some contribution of money and relief to be levied and collected of the same clergy,. . "418 In other cases, Elizabeth addressed letters to Parker and others, with the others being other bishops or at the least members of the clergy. However, this letter is addressed only to Parker. She was only making this request of him. She knew the level of Parker's devotion to her and knew that he would not refuse her.

Throughout the rest of Parker's life and tenure as archbishop, he and Elizabeth exchanged letters about uniformity within the church doctrine and practices. In a letter dated January 25, 1564-5, Elizabeth wrote to Parker about the need for uniformity within the Church of England. ${ }^{419}$ She observed that diversity in religious practices would only "provoke the displeasure of Almighty God," and it was up to them to rectify the problem and enforce uniformity. ${ }^{420}$ Uniformity still referred to the Act of Uniformity (1559) that stated that all services in England should abide by The Book of Common Prayer. Parker wrote a letter to Bishop Sandys of London on November 24, 1573, regarding the enforcement of uniformity in the church. He asked the bishop to lead an inquisition to ascertain how well the queen's request for uniformity was coming along. ${ }^{421}$

\footnotetext{
417 Ibid.

${ }^{418}$ Bruce and Thomason Perowne, eds., The Correspondence of Matthew Parker D.D., Archbishop of Canterbury, 143.

${ }^{419}$ Ibid., 224.

420 Ibid.

${ }^{421}$ Ibid., 451.
} 
Parker knew that taking on the See at Canterbury was a difficult job. Parker was loyal to Elizabeth and did all he could to please her and obey her. He saw it as his duty to obey his queen but he also felt devoted due to the promise he made to her mother back in 1536. Throughout his letters, Parker almost always deferred to Elizabeth's desires. The most important example is his acceptance of the See of Canterbury. Parker was content to remain at Cambridge when Elizabeth asked him to accept the archbishopric at Canterbury. He mentioned his devotion and promise to Anne Boleyn in his correspondence several times and cited that as his reason for agreeing to take on the See at Canterbury. This devotion to keep his promise to Anne Boleyn was the main force behind Parker's loyalty to Elizabeth. Parker remained in office until his death on May 17, 1575. He served his queen and kept his promise to her mother to the best of his ability.

When Parker died, the Bishop of London, Edmund Grindal, took his place as Archbishop of Canterbury. Elizabeth did not get along as well as with Grindal as she had with Parker. Grindal favored Puritanism, a small sect of Protestantism that believed in only practicing religion based on what was in the Bible, and was often at odds with Elizabeth. ${ }^{422}$ Christopher Hibbert provides an example in his book, The Virgin Queen, where Grindal refused to obey Elizabeth regarding suppressing some meetings. Elizabeth felt they would do more harm than good if they continued to gather because she felt they were attended by "the vulgar sort." ${ }^{423}$ Hibbert quotes Grindal when he gave his explanation to Elizabeth regarding why he continued the meetings. Grindal said that he must "choose rather to offend your earthly Majesty than to offend the heavenly Majesty

\footnotetext{
422 Colin Buchanan, Historical Dictionary of Anglicanism (Lanham, MD: Scarecrow Press, INC., 2006), 376-379.

${ }^{423}$ Hibbert, The Virgin Queen, 96.
} 
of God. Remember, Madam, that you are a mortal creature." ${ }^{424}$ Elizabeth eventually suspended Grindal from his duties as archbishop shortly before his death in 1583 .

Elizabeth's next archbishop, John Whitgift, was more inclined to following the queen's orders. He enforced the clergy's acceptance of the Thirty-Nine Articles, passed by Parliament in 1577 , by threatening them with suspension if they refused. ${ }^{425}$ Whitgift and Elizabeth shared many of the same beliefs and worked well together. Elizabeth supported Whitgift in some of his decrees, including one that threatened imprisonment if anyone printed religious material that was not sanctioned by the Bishop of London or the Archbishop of Canterbury. ${ }^{426}$ And Whitgift obeyed Elizabeth in the enforcement of her religious laws and policies.

Elizabeth and Parker worked well together but Elizabeth and her political advisors made the major decisions regarding the church. Their relationship affected the church in England because the majority of the decisions made regarding the church and religious laws were made by Elizabeth but Parker supported them. Parker did not oppose her and often agreed with her course of action, even though he resented accepting the archbishopric. Together they implemented conservative policies that were meant to cause few rumblings among both the Catholic and Protestant factions in England. By embracing this conservatism, they were able to navigate the middle ground between Catholicism and Protestantism that provided stability during the last years of the Tudor Era.

${ }^{424}$ Ibid.
${ }^{425}$ Ibid.
${ }^{426}$ Ibid. 


\section{CONCLUSION}

Each monarch and archbishop of Canterbury had their own unique relationship with one another. Cranmer was a friend to Henry VIII but he also kept many secrets from his king for fear of punishment. However, with Edward, Cranmer was more of a paternal figure, guiding his young protégé to create a reformed England. Pole and Mary grew close because of their devotion to their religion and the pope. Pole cared about Mary's welfare and he did all he could to ensure her happiness. Parker was devoted to Elizabeth and sacrificed his own happiness to serve her and keep his word to her mother. Elizabeth understood the depth of his devotion and used it to her advantage. She appreciated Parker but more for what he would do for her rather than any personal affection. The relationship between the monarchs of Tudor England and their archbishops of Canterbury were all unique. The Tudor period from Henry VIII to Elizabeth I was a time of change, especially in the church. The rulers and archbishops worked together to ensure the prosperity of England and from those working relationships came a respect and understanding of one another. The examination of each relationship reveals personal details about the monarchs and the archbishops and shows how differently each pair interacted with each other, and how they affected the Church in England.

The break with Rome resulted in Henry and the men around him building a new institution called the Church of England, of which Henry declared himself the Supreme Head. Henry and his successors all had their own impact on England in general and the 
Anglican Church in particular when they succeeded to the throne. Each monarch brought his or her own personal goals to the church and assumptions as to how it should function under the crown. Henry, his son Edward VI, and his daughters Mary and Elizabeth, altered the Church during their reigns. All relied on their archbishops of Canterbury to carry out their religious policies. In some cases, the archbishops and monarchs developed a close relationship as they worked together, as with Mary and Reginald Pole. In other instances, the two worked together using one another to meet their own goals with regard to the Church. Regardless of what either the monarch or the archbishop sought to do, relationships formed, and those relationships were different between each monarch and archbishop. These bonds between the monarchs and archbishops are responsible for how the Anglican Church formed and what religious policies were implemented during the reigns of the monarchs in question.

Henry VIII had two archbishops during his reign. The first was William Warham who also served as archbishop under Henry's father, Henry VII. He died in 1532 and Thomas Cranmer succeeded him in 1533. Cranmer became one of Henry's most trusted advisors and the two men developed a mutual respect for one another. Their relationship began before Cranmer became archbishop of Canterbury. While the break with Rome was mostly the work of Henry, Cranmer played a major part in helping Henry separate from Rome and create the Church of England. He worked alongside Henry to find a reason based in scripture to end his first marriage and allow him to marry another, without spiritual repercussions.

Following the end of the king's first marriage, Cranmer worked alongside Henry in religious matters as his trusted archbishop. However, following the break with Rome, 
Cranmer began to lean more towards Protestantism although he would not officially became Protestant until the reign of King Edward VI. Cranmer began his own work on reforming the church in England, such a beginning his Book of Homilies that became a key part of the Anglican Church under Edward and Elizabeth. Henry remained a Catholic in practice until his death and still did not agree with most of what the Protestant reformers preached. Cranmer had to be careful how much of his efforts the king was aware of at this point. For example, Cranmer married a woman in secret before he accepted his position as archbishop. Cranmer did not end the marriage nor did he come out with it publicly. He kept the marriage a secret from Henry until about 1543, at which point Henry pardoned Cranmer for his actions.

When others fell from favor, such as Anne Boleyn and Thomas Cromwell, Cranmer remained in his office and with the king's favor. Cranmer developed a close relationship with the Boleyn family while he wrote his book in defense of the king's annulment from Katherine of Aragon but when Anne fell from favor, Cranmer did not. Cranmer wrote to the king and expressed his distress to learn of the queen's dishonor and how much it hurt the king. He did the same thing when Cromwell fell from favor and was executed for treason. Despite his close relationships with two people who were executed at the king's orders, Cranmer remained unscathed, due to his constantly reaffirmed loyalty to Henry.

Cranmer displayed his loyalty to the king above all else and the king showed his gratitude for this loyalty by granting leniency to Cranmer when he learned of his more radical beliefs and actions, such as his marriage and his writings about faith and reform. Both men got what they wanted from the relationship and it worked to their mutual 
advantage. Henry was able to establish his supremacy over the church in England and Cranmer was able to build a foundation for reforming the church in the future. Despite the growing differences between the two men, Cranmer and Henry remained close until Henry's death in 1547. Cranmer was at Henry's side and held his hand when the king died.

Henry passed the crown to his son, Edward, who was only nine years old at the time. Due to Edward's age, a regency council was created to help him rule until he was old enough to rule on his own. The council included his uncles on his mother's side, Thomas Seymour and Edward Seymour, who became Lord Protector Somerset. Cranmer was also a part of the advisory council and played a major role in determining the religious path of England. England and Rome had been separated since the 1530s and there would be no reconciliation under Edward's rule. Since many of Edward's council members identified with Protestantism rather than Catholicism, they took the opportunity to continue England on the path toward Protestant reform. Henry unintentionally started England on this journey but Cranmer and Edward's council, through Edward, finished the work to make England a Protestant state. While Henry did not intend England to become at all Protestant, he set in motion the chain of events that would make the Church in England a Protestant institution.

Cranmer was Edward's godfather, as well as a councilor and tutor. When Edward came to the throne he also became the new Supreme Head of the Church of England. His tutors favored Protestantism and due to this influence, so did the young king. Under Edward, Cranmer molded the Church into the reformed body it became by the end of Edward's reign. Cranmer published his Book of Common Prayer and a book of sermons 
along with his doctrines about the faults in Catholicism, that included many of Cranmer's original works. Under Cranmer and Edward, Parliament passed the Act of Uniformity that demanded that an English Bible be placed in each church. Priests were expected to preach out of the approved book of sermons, written in large part by Cranmer.

Cranmer was a paternal figure to Edward, even before the death of Henry VIII. He wrote to him and praised his academic work while also praising him and comparing him to King Josiah. Cranmer wanted to see through the reformation he helped Henry start and he commissioned the young king to see it through and bring his people to salvation. Edward was a dedicated Protestant and under the influence of Cranmer and the regency council, he turned England to Protestantism. Edward respected, listened to, and followed Cranmer's advice on many religious issues. Through the relationships between Cranmer, Edward, and Edward's councilors, Cranmer's goal of a Protestant England was achieved and even though Mary would undo many of their accomplishments, Elizabeth and her regime reinstated much of Cranmer and Edward's work.

When Edward died at age fifteen, he left the country to his oldest half-sister, Mary. Mary, a devout Catholic, set out to undo all of her brother's work and restore the Catholic Church to what it was before her father broke with Rome. To help her see this through, Pope Julius III sent Reginald Pole to England as papal legate. Pole, a native of England and former friend of Henry VIII before his exile, was determined to return England to the Roman Catholic religion. Pole and Mary shared this dream and while it took over a year for Pole to be readmitted into England, once he returned they began to work together to reconcile Rome and England. 
Both Mary and Pole were devoted to their faith and Pole kept in almost constant correspondence with Mary when they were apart. When he came back to England, he was rarely away from her side. When Mary married Philip II of Spain, Pole discouraged the match because he feared that Charles V, her cousin and Philip's father, would influence her into doing something not in the interest of England but in the interest of Spain. Pole wrote to Mary and advised her on what he saw as the best course of action for the religious atmosphere. Pole grew frustrated with Mary when she took so long to heed his advice but his anxiety quieted when his order of exile was finally lifted by Parliament and he was allowed back into England.

When he arrived in England, Mary was experiencing the first of her two hysterical pregnancies. Once it became clear that Mary was not pregnant, Philip left England to oversee the rest of his empire. In his absence, Philip left instructions for Mary, Pole, and members of Parliament on how they should run the country while he was gone. Part of Philip's instructions to Pole before he left was that Pole should remain by Mary's side and comfort and counsel her. Pole kept regular correspondence with Philip while he was away and told the monarch how unhappy Mary was since Philip's departure. Pole showed his affection for Mary by writing to her husband and requesting his return, for her sake. Pole knew that only her husband's return would truly console her. He updated Philip on Mary's condition in almost every letter they exchanged.

Pole and Mary grew close during Philip's absence because they shared the goal of reuniting England and Rome and restoring the Catholic Church in England. This made for a strong working relationship but the amount of time they spent together also helped them to build a personal relationship. Their tireless work laid a strong foundation to 
rebuild the Catholic Church in England but their deaths prevented their work from being completed. Pole wept at the news of Mary's passing on November 17, 1558 before taking his last breath a few hours later.

When Mary died, her younger half-sister, Elizabeth came to the throne. Elizabeth had no intention of maintaining the Catholic Church Mary rebuilt during her reign. Elizabeth adhered to the brand of religion of her father with some influence from her brother, rather than the strict Catholicism that Mary favored. One of the first things she did was to pass the Act of Supremacy of 1559, which renamed the monarch's title in the Church of England as the Governor of the Church as opposed to the previous title of Supreme Head. A second act passed by Parliament was the Act of Uniformity, which introduced a revised version of the Book of Common Prayer and other alterations from Elizabeth. She also passed a series rules for the church called the Injunctions of 1559. Parliament passed these laws before her new Archbishop of Canterbury, Matthew Parker, officially took office.

Parker was reluctant to become archbishop and he only accepted the position because of a promise he made to Elizabeth's mother, Anne Boleyn. Anne Boleyn asked Parker to watch over Elizabeth and her spiritual welfare shortly before she was arrested in 1536. Parker claimed that this promise is what pushed him to accept the offer to be the next Archbishop of Canterbury. He deferred to her will, as he did in many other cases, and accepted the responsibility of the See of Canterbury.

When he took office, he quickly set to work ensuring that the Act of Uniformity was enforced throughout England as well as ensuring that all the Injunctions of 1559 were upheld. However, he also advised Elizabeth in several matters. He advised her on 
matters of uniformity, but most importantly he advised her to marry. He did his duty to her mother by advising Elizabeth to marry so she could ensure England's religious future and have a Protestant monarch from her bloodline succeed her, and not the Scottish royal family who were her heirs according to Henry's Act of Succession.

Elizabeth appreciated his advice and took some of it but she never did marry. Elizabeth seemed to keep Parker at arm's length and took the advice of her political advisors over Parker's. Parker also kept in contact with William Cecil, Elizabeth's chief advisor. Parker told Cecil that he would never have taken the See at Canterbury, except that he felt honor bound to the queen's mother. He remained a devoted servant to the queen until his death in 1575 . While Elizabeth appreciated his guidance, she usually took the advice of Cecil or did what she wanted to do.

Through the examination of each of these relationships between archbishops and monarchs one can see how they affected the church in England. Cranmer and Henry worked together to implement some reform within the church but Henry wanted the mass and doctrine to remain unchanged. Cranmer did not want to anger Henry by introducing any of his more radical ideas of reform so the church under Henry made more conservative changes compared to the changes made under Edward. Cranmer continued his reform under Edward and used his influence to enforce more of his own ideas and works in the church. Edward and Cranmer put into effect more of Cranmer's reforms, showing how much more Edward favored Protestantism and that Cranmer had a greater influence over Edward compared to Henry.

Mary and Pole had a more personal relationship than any of the other archbishops and monarchs. They bonded over their devotion to Catholicism and their desire to see 
papal authority restored in England. Their cooperation with one another and determination to restore Catholicism in England allowed them to restore many aspects of the Catholic Church in England, such as the mass and papal authority. Elizabeth and Parker's relationship was similar to that of Henry and Cranmer. They respected one another but Elizabeth and her political advisors usually made the final decision regarding religious policy rather than Parker and Elizabeth. Parker had more Protestant sympathies than Elizabeth but the church under the two of them stayed conservative in its policies, much as Elizabeth did in her beliefs.

These relationships between the archbishops and monarchs can show how and why the Church in England functioned the way it did throughout the Tudor period. Sometimes the archbishop could influence the monarch to endorse their policies, as with Cranmer and Edward. Other times, the monarch had almost complete control, as was the case with Henry and Cranmer as well as Elizabeth and Parker. And then there can be an instance where the archbishop and monarch agree and work in relative agreement with one another, such as with Mary and Pole. 
Primary Sources

\section{REFERENCES}

Bruce Esq., John and Rev. Thomas Thomason Perowne, M.A. Eds. The Correspondence of Matthew Parker D.D., Archbishop of Canterbury. Cambridge: Cambridge University Press, 1853.

Cox, Rev. John Edmund, ed. Writings and Disputations of Archbishop of Canterbury, Martyr, 1556, Relative to the Sacrament of the Lord's Supper. Vol. 1 of The Works of Thomas Cranmer, Archbishop of Canterbury, Martyr 1556 Cambridge: Cambridge University Press, 1844.

. Miscellaneous Writings and Letters of Thomas Cranmer, Archbishop of Canterbury, Martyr, 1556. Vol. 2 of The Works of Thomas Cranmer, Archbishop of Canterbury, Martyr 1556 Cambridge: Cambridge University Press, 1846.

Cummings, Brian, ed. The Book of Common Prayer: The Texts of 1549, 1559, and 1662. Oxford: Oxford University Press, 2011.

Thomas F. Mayer and Courtney B. Walters. The Correspondence of Reginald Pole, 4 vols. Aldershot, England: Ashgate, 2003.

Pole, Reginald and Joseph G. Dwyer, translator. Defense of the Unity of the Church. Westminster: Newman Press, 1965.

Secondary Sources

Ackroyd, Peter. Tudors: The History of England from Henry VIII to Elizabeth I. New York: Thomas Dunne Books, 2012.

Ashton, Robert. Reformation and Revolution 1558-1660. London: Grand Publishing Limited, 1984.

Bernard, G.W. The King's Reformation: Henry VIII and the Remaking of the English Church. New Haven: Yale University Press, 2005.

- "The Making of Religious Policy, 1533-1546: Henry VIII and the Search for the Middle Way.” The Historical Journal 41 (June 1988): 321-349.

Brook, V.J.K. A Life of Archbishop Parker. Oxford: Clarendon Press, 1962. 
Buchanan, Colin. Historical Dictionary of Anglicanism. Lanham, MD: Scarecrow Press, INC., 2006.

Davis, John F. Heresy and Reformation in the South-East of England, 1520-1559. London: Royal Historical Society, 1983.

Dickens, A.G. The Counter Reformation. Great Britain: Jarrold and Sons LTD, 1969. . The English Reformation. New York: Schocken Books, 1964.

Duffy, Eamon and D.M. Loades, eds. The Church of Mary Tudor. Burlington, Vermont: Ashgate Publishing Company, 2006.

And David Loades, eds. The Church of Mary Tudor. Aldershot Hants, England: Ashgate, 2006.

Duffy, Eamon. Fires of Faith: Catholic England under Mary Tudor. New Haven: Yale University Press, 2009. . The Stripping of the Altars: Traditional Religion in England c. 1400-1580. New Haven: Yale University Press, 1992.

Edwards, John. Archbishop Pole. Burlington, VT: Ashgate Publishing Company, 2014.

Elton, G.R. Reform and Reformation: England, 1509-1558. Cambridge, MA: Harvard University Press, 1977.

Erickson, Carolly. Bloody Mary. Garden City, NY: Doubleday, 1978.

Fletcher, Catherine. The Divorce of Henry VIII: The Untold Story from Inside the Vatican. New York: Palgrave Macmillan, 2012.

Fraser, Antonia. The Wives of Henry VIII. New York: Vintage Books, 1992.

Frere, W.H. The English Church in the Reigns of Elizabeth and James I. (1558-1625). Vol. 5 of The English Church. New York: AMS Press, 1904.

Gairdner, James. The English Church in the Sixteenth Century from the Accession of Henry VIII to the Death of Mary. Vol. 4 of The English Church. New York: AMS Press, 1902.

Guy, John. Tudor England. Oxford: Oxford University Press, 1988. , ed. The Tudor Monarchy. London: Arnold, 1997.

Green, Toby. Inquisition: The Reign of Fear. New York: Thomas Dunne Books, 2007. 
Haigh, Christopher, ed. The Reign of Elizabeth I. Athens: The University of Georgia Press, 1985.

Hibbert, Christopher. The Virgin Queen: Elizabeth I, Genius of the Golden Age. Reading, MA: Addison-Wesley Publishing Company, Inc., 1991.

Hoak, Dale, ed. Tudor Political Culture. Cambridge: Cambridge University Press, 1995.

Hutchinson, F.E. Cranmer and the English Reformation. London: English Universities Press LTD., 1951.

Jones, Whitney R.D. The Mid-Tudor Crisis 1539-1563. London: Macmillian Press, Ltd., 1973.

Levin, Carole. "The Heart and Stomach of a King": Elizabeth I and the Politics of Sex and Power. Philadelphia: University of Pennsylvania Press, 1994.

Loach, Jennifer. Edward VI. Edited by George Bernard and Penry Williams. New Haven: Yale University Press, 1999. and Robert Tittler, eds. The Mid-Tudor Polity, c. 1540-1560. Totowa, New Jersey: Rowman and Littlefield, 1980.

Loades, D. M. Mary Tudor: A Life. Oxford: Oxford University Press, 1990.

. The Reign of Mary Tudor: Politics, Government, and Religion in England, 1553-1558. New York: St. Martin's Press, 1979.

. The Tudor Court. Bangor, UK: Headstart History, 1992.

. Two Tudor Conspiracies. Cambridge: Cambridge University Press, 1965.

MacCulloch, Diarmaid. The Boy King: Edward VI and the Protestant Reformation. New York: Palgrave, 2001. , ed. The Reign of Henry VIII: Politics, Policy, and Piety. New York: St. Martin's Press, 1995. . Thomas Cranmer: A Life. New Haven: Yale University Press, 1996.

Marshall, Peter, ed. The Impact of the English Reformation 1500-1640. London: Arnold, 1997.

Mayer, Thomas F. "Reginald Pole in Paolo Giovio's Descriptio: A Strategy for Reconversion." The Sixteenth Century Journal 16 (1985): 431-450.

Maynard, Theodore. Bloody Mary. Milwaukee: The Bruce Publishing Company, 1955. 
Norwich, John Julius. Absolute Monarchs: A History of the Papacy. New York: Random House, 2011.

Pill, David H. The English Reformation 1529-58. Totowa, NJ: Rowan and Littlefield, 1973.

Pogson, Rex H. "Reginald Pole and the Priorities of Government in Mary Tudor's Church." The Historical Journal 18 (March 1975): 3-20.

Porter, Linda. The First Queen of England: the Myth of "Bloody Mary." New York: St. Martin's Press, 2008.

Prescott, H. F. M. Mary Tudor. London: Eyre \& Spottiswoode, 1952.

Richards, Judith. Mary Tudor. London: Routledge, 2008.

Ridley, Jasper. Thomas Cranmer. Oxford: Oxford University Press, 1962.

Roll, Winifred. Mary I: The History of an Unhappy Tudor Queen. Englewood Cliffs, NJ: Prentice Hall, Inc., 1980.

Shagan, Ethan H. Popular Politics and the English Reformation. Cambridge: Cambridge University Press, 2003.

Smith, Lacey Baldwin. "The Last Will and Testament of Henry VIII: A Question of Perspective." Journal of British Studies 2 (November 1962): 14-27. . Treason in Tudor England: Politics and Paranoia. Princeton: Princeton University Press, 1986.

Starkey, David. Elizabeth: The Struggle for the Throne. New York: Harper Collins Publishers, 2001.

Thorp, Malcolm R. "Religion and the Wyatt Rebellion of 1554." Church History 47 (December 1978): 363-380.

Tittler, Robert. The Reign of Mary I. London: Longman Group Limited, 1983.

Tyacke, Nicholas, ed. England's Long Reformation 1500-1800. London: University College London, 1998.

Waldman, Milton. The Lady Mary: A Biography of Mary Tudor, 1516-1558. New York: Scribner, 1972.

Weir, Alison. Henry VIII: The King and His Court. New York: Ballentine Books, 2001. 
. The Children of Henry VIII. New York: Ballantine Books, 2008.

. The Lady in the Tower: The Fall of Anne Boleyn. New York: Ballantine Books, 2010.

Yost, John K. "The Reformation Defense of Clerical Marriage is the Reigns of Henry VIII and Edward VI." Church History 50 (June 1981): 152-165. 


\author{
CURRICULUM VITAE \\ Mary Alexandra Covington \\ Cell phone: (859)-466-6614 \\ 787 Chestnut Street, Meadville, PA 16335 Email: acov10s@gmail.com
}

Date: August, 2015

\title{
EDUCATION
}

Master in Arts, University of Louisville, Louisville, Kentucky, August 2015

Major: History with British history concentration, Minor: Public History

GPA: $3.83 / 4.0$

Bachelor of Arts and Sciences, University of Indianapolis, Indianapolis, Indiana, May

2013

Major: History with U.S. concentration, Minor: Spanish

GPA: $3.7 / 4.0$

\section{RESEARCH EXPERIENCE}

- Primary research in the University of Indianapolis Frederick D. Hill Archives- read through archived Reflector articles, archived yearbooks, and university commissioned studies.

- Conducted multiple interviews with Dr. Sue Willey as research for a paper "We Are the Whippets!: Title IX and Gender Equity at the University of Indianapolis."

\section{TEACHING AND TUTORING}

- Graduate Teaching Assistant at the University of Louisville 2014-2015

- Tutored fellow students in history, math, and Spanish, 2009-2013.

- Service learning project with the Asante Children's Theatre, assisting the production with its historical accuracy.

\section{AWARDS AND HONORS}

Honorable Mention for Phi Alpha Theta 2015 Essay Contest

Graduate Teaching Assistantship at the University of Louisville, 2014-2015

Internship at the Filson Historical Society, 2013-2014

Richard Lugar Academic Scholarship

Dean's List and Honor Roll 2009-2012

President of Phi Alpha Theta 2011-2013

ITA Scholar Athlete 2010-2012

Academic All-Conference Team 2011

National Honor Society Member

First Honor Student, 2005-2009

\section{CO-CURRICULAR EXPERIENCES}

- Phi Alpha Theta 2011-2013 (President 2011-2013)- Organized and assisted with events associated with the group.

- Women's Varsity Tennis, University of Indianapolis, 2 Varsity letters, 2009-2013

- National Honor Society, Villa Madonna Academy, 2008-2009 
-Women's Varsity Tennis, Villa Madonna Academy, 4 Varsity letters, 2005-2008 (MVP 2005-2008)

VOLUNTEER SERVICE

- Indianapolis Breast Cancer Walk October, 2012

- The Lord's Kitchen, Indianapolis 2012

- Make A Wish Foundation 2012-2013

- University of Indianapolis's Riley Hospital Dance Marathon 2013

EMPLOYMENT

- Graduate Teaching Assistant 08/2014-Present

- Intern at the Filson Historical Society 08/2013-04/2014

- Dorm Director, Camp Counselor, and Tennis Coach at Stanford Nike Tennis Camps 06/2011-08/2012

- Tennis Instructor at the University of Indianapolis Tennis Center 10/20094/2010

REFERENCES

Available upon request. 